\title{
Fanworms: Yesterday, Today and Tomorrow
}

\author{
María Capa ${ }^{1, *(\mathbb{D}}$, Elena Kupriyanova ${ }^{2}$, João Miguel de Matos Nogueira ${ }^{3}\left(\mathbb{D}\right.$, Andreas Bick ${ }^{4}$ \\ and María Ana Tovar-Hernández ${ }^{5}$
}

1 Departament de Biologia, Universitat de les Illes Balears, 07122 Palma, Spain

2 Australian Museum Research Institute, Australian Museum, Sydney, NSW 2010, Australia; elena.kupriyanova@australian.museum

3 Departamento de Zoologia, Instituto de Biociências, Universidade de São Paulo, São Paulo 05508-090, Brazil; nogueira@ib.usp.br

4 Institut für Biowissenschaften, Allgemeine und Spezielle Zoologie, Universität Rostock, Universitätsplatz 2, D-18055 Rostock, Germany; andreas.bick@uni-rostock.de

5 Facultad de Ciencias Biológicas, Universidad Autónoma de Nuevo León, Nuevo León 66455, Mexico; maria_ana_tovar@yahoo.com

* Correspondence: maria.capa@uib.es

Citation: Capa, M.; Kupriyanova, E.; Nogueira, J.M.d.M.; Bick, A.; Tovar-Hernández, M.A. Fanworms: Yesterday, Today and Tomorrow. Diversity 2021, 13, 130. https:// doi.org/10.3390/d13030130

Academic Editor: Luc Legal

Received: 30 December 2020

Accepted: 10 March 2021

Published: 17 March 2021

Publisher's Note: MDPI stays neutral with regard to jurisdictional claims in published maps and institutional affiliations.

Copyright: (c) 2021 by the authors. Licensee MDPI, Basel, Switzerland. This article is an open access article distributed under the terms and conditions of the Creative Commons Attribution (CC BY) license (https:// creativecommons.org/licenses/by/ $4.0 /)$.

\begin{abstract}
Sabellida Levinsen, 1883 is a large morphologically uniform group of sedentary annelids commonly known as fanworms. These annelids live in tubes made either of calcareous carbonate or mucus with agglutinated sediment. They share the presence of an anterior crown consisting of radioles and the division of the body into thorax and abdomen marked by a chaetal and fecal groove inversion. This study synthesises the current state of knowledge about the diversity of fanworms in the broad sense (morphological, ecological, species richness), the species occurrences in the different biogeographic regions, highlights latest surveys, provides guidelines for identification of members of each group, and describe novel methodologies for species delimitation. As some members of this group are well-known introduced pests, we address information about these species and their current invasive status. In addition, an overview of the current evolutionary hypothesis and history of the classification of members of Sabellida is presented. The main aim of this review is to highlight the knowledge gaps to stimulate research in those directions.
\end{abstract}

Keywords: Sabellida; Sabellidae; Serpulidae; Fabriciidae; Annelida; polychaetes; biodiversity assessment; systematics; methods; gaps of knowledge

\section{Introduction}

Sabellida Levinsen, 1883 is a morphologically uniform clade of sedentary annelids historically given a rank of Order. Sabellida currently includes members of Fabriciidae Rioja, 1923, Sabellidae Latreille, 1825, and Serpulidae Rafinesque, 1815 [1-3]. They are commonly known as fanworms, feather-duster worms, or flowers of the sea, because their radioles are arranged in a crown, protruding from the tube made of calcium carbonate or mucus with agglutinated sediment (Figure 1). In addition to the presence of protective tube and the prostomial crown made of radioles with secondary ramifications (generally referred as pinnules, but see [4] for Fabriciidae), which are mainly used for feeding and respiration, all members of Sabellida share the presence of chaetal inversion [thoracic chaetigers with simple chaetae on notopodia and uncini (hooks) on neuropodia, and abdominal chaetigers with opposite arrangement]. Sabellida includes about 1200 species distributed world-wide, from tropical to polar waters and found in all habitats, from freshwater to fully marine conditions, and intertidal to deepest ocean trenches. 


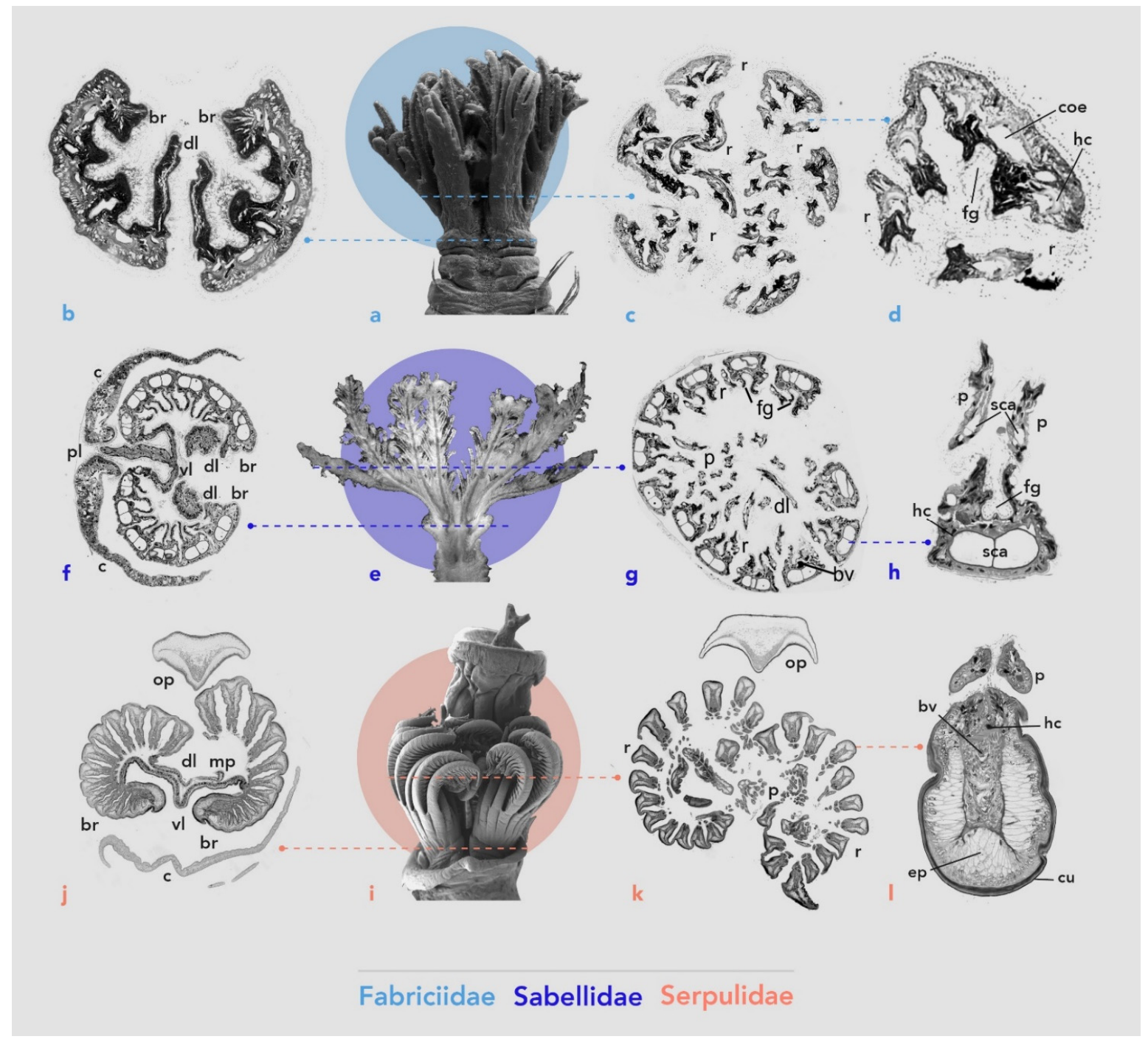

Figure 1. Comparison of the radiolar crown structure among the three families of Sabellida. (a) Anterior end of Fabricia stellaris, dorsal view; (b) Histological section of crown of F. stellaris at base; (c) Histological section of crown of F. stellaris at mid-length; (d) Histological section of one radiole and presumed pinnules of F. stellaris; (e) Anterior end of Laonome xeprovala, dorsal view; (f) Histological section of crown of Laonome xeprovala at base; (g) Histological section of crown of $L$. xeprovala at mid-length; (h) Histological section of one radiole and pinnules of L. xeprovala; (i) Anterior end of Spirobranchus lamarki, ventral view; (j) Histological section of crown of S. lamarcki at base; (k) Histological section of crown of S. lamarcki at mid-length; (1) Histological section of one radiole and pinnules of S. lamarcki. Abbreviations: br: base of radioles; bv: blood vessel; c: collar; coe: coelom; cu: cuticle; dl: dorsal lips; ep: epithelium; fg: faecal groove; hc: hyaline cartilage; mp: mouth palp; op: opercular peduncle; p: pinnules; pl: parallel lamellae; r: radioles; sca: supporting cellular axis; vl: ventral lips.

The Sabellida concept and even the group name has changed over time. Since their erection in the early 19th century, sabellids (including fabriciids), building soft sediment tubes, and serpulids, building calcareous tubes, have always been considered related, based on their general morphology and grouped into the section Amphitrites sabelliennes [5], the family Serpulacei [6], family Serpulacea [7-9], Serpulidae [10], and finally Sabellida [11,12].

With the advent of cladistic analyses, close relationships of sabellids and serpulids with Sabellariidae Johnston, 1865, Siboglinidae Caullery, 1914 and Oweniidae Rioja, 1917 have been suggested, and consequently the composition of Sabellida expanded to incorporate these three taxa (e.g., [13]) (Figure 2). However, subsequent molecular analyses using increasing number of taxa and DNA markers revealed that the three late incorporated taxa were neither closely related to fanworms, nor to each other [14-16]. 
Morphological lines of evidence related to the ontogeny, internal anatomy, position of the ciliated groove, as well as chaetal morphology and arrangement also supported this lack of close relationship [17-26]. Consequently, Sabellida now again includes only fanworms (Figure 2), but the former sabellid subfamily Fabriciinae has been elevated to Fabriciidae based on DNA evidence $[1-3,24,27]$. The sister group of Sabellida, according to the latest phylogenomic studies, is a clade including Spionidae Grube, 1850 and Sabellariidae $[14,28,29]$.

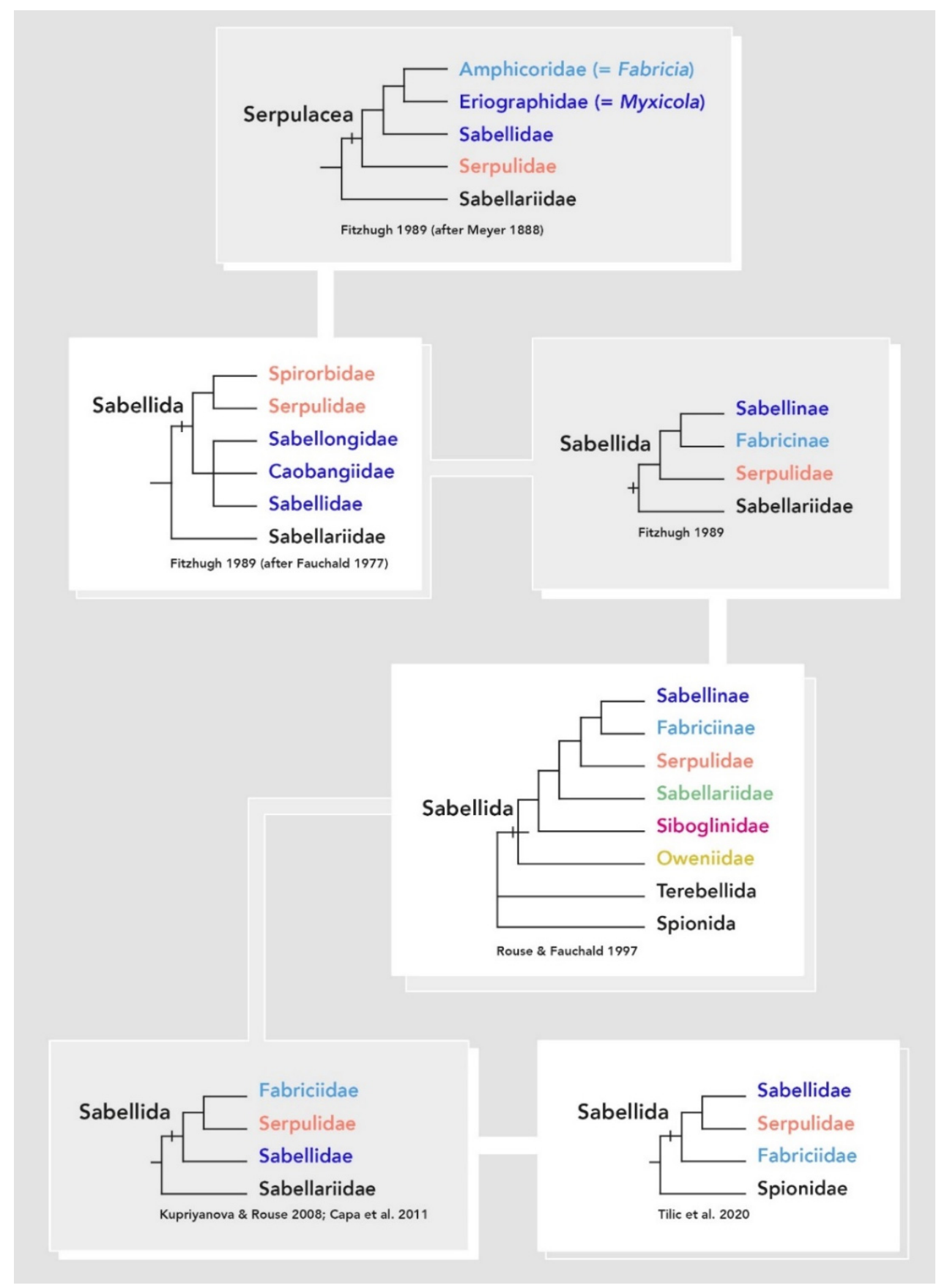

Figure 2. History of the evolutionary hypotheses within Sabellida. The coloured taxa indicate the groups that had been considered as members of Sabellida (or Serpulacea) according to the represented phylogenetic hypotheses. In light blue are members of the currently accepted Fabriciidae, in dark blue are Sabellidae and Serpulidae are in orange. In green, pink and yellow are other taxa previously considered as Sabellida. 
Most of the taxonomic work in the Sabellida has aimed to document the regional species diversity, rather than to provide comprehensive world-wide generic revisions. These regional studies have been geographically unevenly distributed because of their strong association to political, economic, historical and traditional context. Moreover, available georeferenced databases (i.e., in Global Biodiversity Information Facility, GBIF, https:/ / www.gbif.org (accessed on 3 March 2021)) are also biased, as not all biodiversity information from museum collections and research institutions is shared with this service. The information available in GBIF database not necessarily adequately reflects true species richness and abundance in natural habitats, as more conspicuous, well-known or easier to identify species are predominant in such datasets.

The main aim of this study is to synthesise in a single, easily accessible publication the current knowledge of evolutionary relationships, classification, species diversity and distribution of Sabellida, paying special attention to the latest surveys and novel methodologies used for species delimitation. As some members of Sabellida are easily translocated by anthropogenic means and establish outside of their native ranges, updated information about their invasive status is provided. Another important goal was to highlight the knowledge gaps in order to stimulate research in those directions.

\section{Materials and Methods}

The present study is a literature review of the information on the Sabellida species diversity, distribution and ecology, highlighting the geographic areas that need further scientific effort and the taxonomic groups that need revisions. The characters and methods used for species delineation have been revised. We summarise the phylogenetic position of Sabellida and the relationships within the group from a historic perspective.

The World Register of Marine Species (WoRMS) [30] database has been key for accounting the number of current valid taxa and analyses of species richness. However, this list has been further revised, including synonymies, new combinations, corrections of names for gender agreement, years of publication, specification of habitats, type localities, and assigning statuses such as inquirenda or indeterminable to taxa (Appendix A).

Scientific names for all taxa are followed by the authority the first time a taxon is mentioned in the text and in the supplementary material tables (Tables S1-S3). However, due to the high number of taxa dealt with in this review, the citations of authorships have not been included in the reference list. Since many species are still reported as having suspiciously wide distributions, generalised type localities (not details of precise collection locations) are included in Tables S1-S3). Original descriptions, details of type localities and synonymies can be found in WoRMS [30].

Biodiversity information (occurrence data) is referred to the geographic regions (realms) proposed by Spalding et al. [31] for the marine and Udvardy [32] for limnic environments with terminological changes by Olson et al. [33]. Type localities instead of currently reported distributions were used to assign each species to a biogeographic realm. Available biodiversity records have been downloaded as global maps with georeferenced occurrences for Fabriciidae, Sabellidae and Serpulidae separately from the Global Biodiversity Information Facility (GBIF platform, [34]). Distribution of the most common taxa at global scale and species richness in each of the marine realms have been analysed and discussed. In order to delimit these realms in the GBIF maps, polygons following the boundaries of these realms have been drawn with the tools given at the GBIF platform.

DNA sequences available at the National Center for Biotechnology Information (NCBI, [35]) and Barcode of Life Data System (BOLDSystems [36]) have been used to assess the state of the genetic information available for each of the three groups of fanworms. Moreover, currents trends, including phylogenomic data are discussed. 


\section{Results}

\subsection{Systematics}

The history of the Sabellida as Fabriciidae + Sabellidae + Serpulidae) has been convoluted. Rafinesque [37] grouped the worms with calcareous tubes as Serpularia, now Serpulidae. The subfamily Spirorbinae was established for small-bodied serpulids with spirally coiled tubes [38] and the subfamily Filograninae for the taxa with pinnulated operculum-bearing radioles or lacking opercula [39]. Thus, Serpulidae was subdivided into Filograninae, Serpulinae, and Spirorbinae until Pillai [40] elevated the Spirorbinae to the family status. However, even first morphology-based phylogenetic analyses suggested that Spirorbinae are more closely related to Serpulinae than to Filograninae [19,41,42] and that Filograninae is paraphyletic [41,43,44]. Moreover, further analyses integrating molecular data [45-49] unequivocally found both traditional Serpulinae and Filograninae paraphyletic, and Spirorbinae nested within Serpulidae. Thus, consensus that recognition of Spirorbidae would make Serpulidae a paraphyletic group has prevailed and the rank of the spirorbids was lowered back to Spirorbinae [50].

Initially, Sabellidae included the large-bodied species of fanworms. Rioja, in 1923 [39], divided Sabellidae in three subfamilies: Fabriciinae Rioja (1923), gathering species with acicular uncini; Myxicolinae (only Myxicola Koch in Renier, 1847), having radioles joined by a membrane for most of their length, abdominal uncinal tori forming almost complete cinctures and tubes made of thick gelatinous mucus; and Sabellinae, characterised by avicular thoracic uncini, often with companion chaetae, distinct faecal groove and ventral shields. Johansson [51] included Myxicola in Fabriciinae. Fauchald [12] followed Rioja's arrangement and recognized Sabellongidae Harman, 1969 (with Sabellonga Hartman, 1969) and Caobangiidae Chamberlin, 1919 (with Caobangia Giard, 1893) as valid taxa.

As a result of the first morphology-based phylogenetic analysis of Sabellidae (as perceived at the time), using Serpulidae as the outgroup [42], only subfamilies Fabriciinae and Sabellinae were recognised and their composition changed dramatically (Figure 2). Caobangia, 1893 was included in Fabriciinae, while Myxicola, Sabellonga and some genera previously considered as fabriciins (Chone Krøyer, 1856, Desdemona Banse, 1957, Euchone Malmgren, 1866, Fabrisabella Hartman, 1969 and Jasmineira Langerhans, 1880) were recovered in Sabellinae. The Sabellinae was defined by the presence of the "radiolar skeleton" composed of at least two rows of vacuolated cells and dorsally fused radiolar lobes [42]. The subfamily Fabriciinae was characterised by the presence of rasp-shaped (having several rows of teeth) abdominal uncini, absence of ventral lips, separated radiolar lobes (except in Caobangia) and the absence of "radiolar skeleton" (except in Caobangia, with one longitudinal row of vacuolated cells). Later Caobangia was transferred to Sabellinae, simplifying the definition for Fabriciinae [52].

Analyses of molecular data have changed the understanding of the relationships within Sabellida. Molecular data provided evidence of Serpulidae being sister to Fabriciinae, and Sabellinae the sister group of this clade [1]. Consequently, Fabriciinae was raised to the family rank (Fabriciidae, Figure 2). Further studies supported the validity of the three families, although relationships among them were not consistently supported $[2,24,27]$. The latest study using transcriptomes for a broad range of sabellids recovered Fabriciidae as sister to a clade of Sabellidae and Serpulidae [3] (Figure 2). Now it is generally accepted that Sabellidae does not include Fabriciidae $[1,2,24,27]$ and is more closely related to Serpulidae than to Fabriciidae [3].

\subsubsection{Fabriciidae}

Monophyly of Fabriciidae is supported by the branching patterns of the radiolar crown, the absence of ventral lips, abdominal uncini with elongate handle referred to as manubrium, and presence of radiolar hearts [4] (Table 1, Figure 3), as well as by reproductive characters [27]. Relationships among fabriciids were first explored using morphological data [42,53-60]. Although the phylogenies were not fully resolved, these studies recovered two main groups: one paraphyletic, branching off at the base of the tree and including 
Fabriciola Friedrich, 1939, Manayunkia Leidy, 1859, Monroika Hartman, 1951, and a clade with the remaining nine genera considered valid at the time. The position of Pseudofabriciola Fitzhugh, 1990b varied with the different analyses [57].

Table 1. Morphological diagnostic features of the three taxa of Sabellida.

\begin{tabular}{|c|c|c|c|}
\hline Feature & Fabriciidae & Sabellidae & Serpulidae \\
\hline Tube material & mucus and sediment/none & mucus and sediment * & calcium carbonate \\
\hline Radiolar lobes & separated & fused & separated \\
\hline $\begin{array}{l}\text { Vacuolated cells supporting } \\
\text { radioles }\end{array}$ & absent & present & absent \\
\hline Operculum & absent & absent & absent or present \\
\hline Thoracic membrane & absent & absent & present \\
\hline Thoracic uncini & acicular & avicular ** & avicular \\
\hline $\begin{array}{l}\text { Number of abdominal } \\
\text { chaetigers }\end{array}$ & $\begin{array}{l}\text { usually three (exceptionally } \\
\text { two or four) }\end{array}$ & more than three & more than three \\
\hline Abdominal uncini & $\begin{array}{l}\text { with elongate and wide } \\
\text { handle (manubrium) }\end{array}$ & $\begin{array}{c}\text { with short handle or lacking } \\
\text { handles }\end{array}$ & lacking handles \\
\hline Branchial hearts & present & absent & absent \\
\hline
\end{tabular}

${ }^{*}$ Glomerula is an exception with a calcareous tube; ${ }^{* *}$ Terebrasabella is an exception with three types of thoracic uncini: acicular, avicular and palmate.

A recent comprehensive study assessing phylogenetic relationships within Fabriciidae incorporated DNA sequence and reproductive data into a morphological dataset [27]. The results corroborated the apomorphies proposed earlier: the absence of ventral lips, modified abdominal uncini with elongate manubrium and presence of radiolar hearts, together with six apomorphic reproductive traits: (1) spermatogenesis occurring only in the thorax, (2) spermatids developed in large clusters with a central cytophore, (3) presence of a single dorsal sperm duct, (4) presence of a sperm nuclear projection, (5) sperm nuclear membrane thickening, and (6) sperm extra-axonemal sheath. The study recovered the two main groups already revealed by Fitzhugh $[42,56,57,61,62]$. One clade contained Manayunkia and Echinofabricia Huang, Fitzhugh and Rouse, 2011 (Genus A in [57]), and branched off basally, sister to all the other Fabriciidae. The second larger clade showed Rubifabriciola Huang, Fitzhugh and Rouse, 2011 (the red-eyed 'Fabriciola'), branching off at the base, sister to six other genera. Some taxa need further study to assess their monophyly since Novafabricia labrus Fitzhugh, 1998 was not found nested within other species in the genus (as in [57]), Monroika africana (Monro, 1939) formed a polytomy with the Manayunkia species, and there were not enough characters to support Augeneriella Banse, 1957 and Pseudoaugeneriella Fitzhugh, 1988 as distinct genera [27].

With one exception, genera of Fabriciidae have been revised and most of the revisions were accompanied by phylogenies (Table 2). Brandtika Jones, 1974 was not included in phylogenetic analyses [27,59] due to poorly preserved types and incomplete descriptions [63]. 


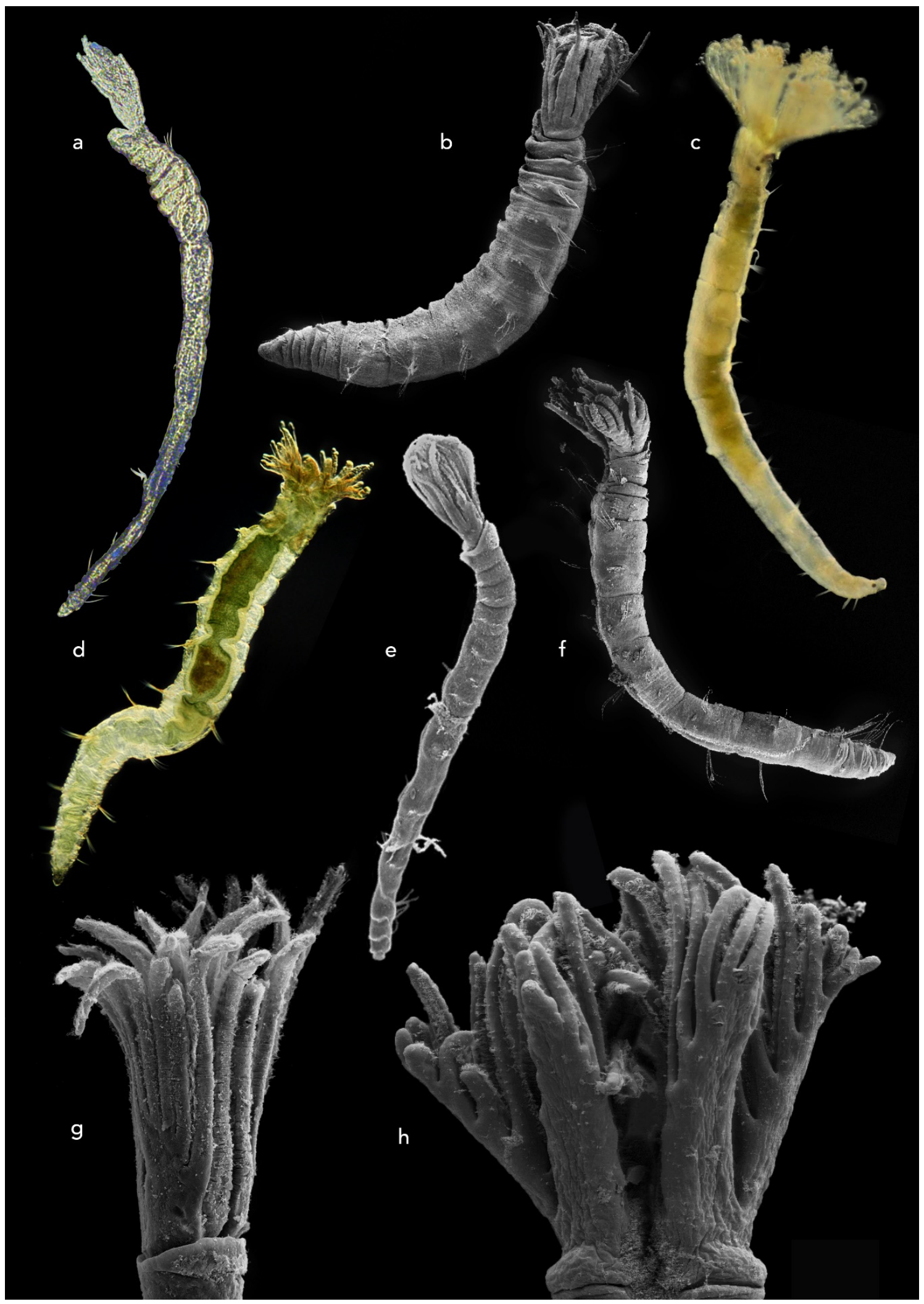

Figure 3. Some fabriciid representatives showing a range of the diversity of forms found in the group. (a) cf. Fabriciola sp., deep-sea basin of the southwest Atlantic; (b,c,h) Fabricia stellaris, Baltic Sea; (d,f) Manayunkia athalassia, South Australia; (e) Fabriciola sp., Brazil (g) Monroika sp., Argentina ((c) by A. Dietrich, (d) by G. Rouse, (g) by L. Armendariz). 
Table 2. Fabriciid currently accepted genera that have undergone major or partial revisions and phylogenetic analyses (based on morphological features, molecular data or both).

\begin{tabular}{|c|c|c|c|}
\hline Genera & Number of Species * & Taxonomic Revision & Phylogenetic Studies \\
\hline Augeneriella Banse, 1957 & 5 & $\begin{array}{c}\text { Banse 1957, Fitzhugh 1983, } \\
\text { 1990a, } 1993\end{array}$ & $\begin{array}{l}\text { Fitzhugh 1991a-b, 1992, 1993, } \\
2010\end{array}$ \\
\hline Bansella Fitzhugh, 2010 & 1 & Fitzhugh 2010 & Fitzhugh 2010 \\
\hline Brandtika Jones, 1974 & 1 & Fitzhugh 2001 & NO \\
\hline Brifacia Fitzhugh, 1998 & 2 & $\begin{array}{l}\text { Fitzhugh 1998; Giangrande et al. } \\
\qquad 2014\end{array}$ & Fitzhugh 2010 \\
\hline $\begin{array}{c}\text { Echinofabricia Huang, Fitzhugh } \\
\text { and Rouse, } 2011\end{array}$ & 4 & Huang et al. 2011 & $\begin{array}{c}\text { Fitzhugh 1991a, 1992, 1993, } \\
\text { 1998, } 2010 \text { (as genus A) }\end{array}$ \\
\hline Fabricia de Blainville, 1828 & 1 & Fitzhugh 1991b, 2010 & $\begin{array}{c}\text { Fitzhugh 1991a, 1992, 1993, } \\
1998,2010\end{array}$ \\
\hline Fabricinuda Fitzhugh, 1990b & 7 & $\begin{array}{l}\text { Fitzhugh 1983, 1990b, 2002a; } \\
\text { López and Rodríguez } 2008\end{array}$ & $\begin{array}{c}\text { Fitzhugh 1991a, 1992, 1993, } \\
\text { 1998, 2002a, 2010; López and } \\
\text { Rodríguez } 2008\end{array}$ \\
\hline Fabriciola Friedrich, 1939 & 6 & $\begin{array}{l}\text { Fitzhugh 1991b, 1992, 1999; Bick } \\
2005\end{array}$ & $\begin{array}{c}\text { Fitzhugh 1991a, 1992, 1993, } \\
\text { 1998, 1999, } 2010\end{array}$ \\
\hline Manayunkia Leidy, 1859 & 10 & $\begin{array}{c}\text { Sitnikova et al. 2014, Atkinson } \\
\text { et al. } 2020\end{array}$ & $\begin{array}{c}\text { Fitzhugh 1991a, 1992, 1993, } \\
\text { 1998, 2010; Sitnikova et al. 2014; } \\
\text { Pudovkina et al. } 2016\end{array}$ \\
\hline Monroika Hartman, 1951 & 1 & Fitzhugh 1992 & Fitzhugh 1992, 1998, 2010 \\
\hline Novafabricia Fitzhugh, 1990c & 11 & $\begin{array}{l}\text { Fitzhugh 1983, 1990c, 1998; Bick } \\
2005\end{array}$ & $\begin{array}{l}\text { Fitzhugh 1991a, 1992, 1993, } \\
1998,2010\end{array}$ \\
\hline Parafabricia Fitzhugh, 1992 & 2 & Fitzhugh 1992 & Fitzhugh 1992, 1993, 1998, 2010 \\
\hline $\begin{array}{c}\text { Pseudoaugeneriella Fitzhugh, } \\
1998\end{array}$ & 5 & Fitzhugh 1998 & Fitzhugh 1998, 2010 \\
\hline Pseudofabricia Cantone, 1972 & 1 & Fitzhugh 1995 & Fitzhugh 1992, 1998, 2010 \\
\hline Pseudofabriciola Fitzhugh, 1990b & 13 & $\begin{array}{l}\text { Fitzhugh 1990c, 1991b, 1993, } \\
\text { 1996, 2002a; Fitzhugh et al. 1994, } \\
\text { Fitzhugh and Simboura } 1995\end{array}$ & $\begin{array}{l}\text { Fitzhugh 1991a-b, 1993, 1994, } \\
\text { 1996, 1998, 2002a, 2010; } \\
\text { Fitzhugh et al. 1994, Fitzhugh } \\
\text { and Simboura } 1995\end{array}$ \\
\hline \multirow{2}{*}{$\begin{array}{c}\text { Raficiba Fitzhugh, } 2001 \\
\text { Rubifabriciola Huang, Fitzhugh } \\
\text { and Rouse, } 2011\end{array}$} & 1 & Fitzhugh 2001 & Fitzhugh 2010 \\
\hline & 10 & Huang et al. 2011 & Huang et al. 2011 \\
\hline
\end{tabular}

* Excluding subspecies.

\subsubsection{Sabellidae}

Monophyly of Sabellidae is supported by the presence of dorsal and ventral lips, the presence of vacuolated cells supporting radioles and pinnules, and the dorsal fusion of the radiolar lobes (Table 1, Figure 4) [2,3,24,42,52]. Currently, monophyletic clades Sabellinae and Myxicolinae are recognized within Sabellidae, the latter is composed of Amphiglenini and Myxicolini [3]. The current composition of the Sabellinae (now Sabellidae) has not changed significantly since the early cladistic analyses [42,52], although nine genera have been erected since (Table 3), and Megalomma Johansson, 1925 was replaced by Acromegalomma Gil and Nishi, 2017 because the name was preoccupied by a group of carabid beetles. Fitzhugh [42] provided diagnoses of all genera accepted at the time, with their potential apomorphies. The most recent review of morphology and diagnostic features of genera and species identification is found in [24]. 


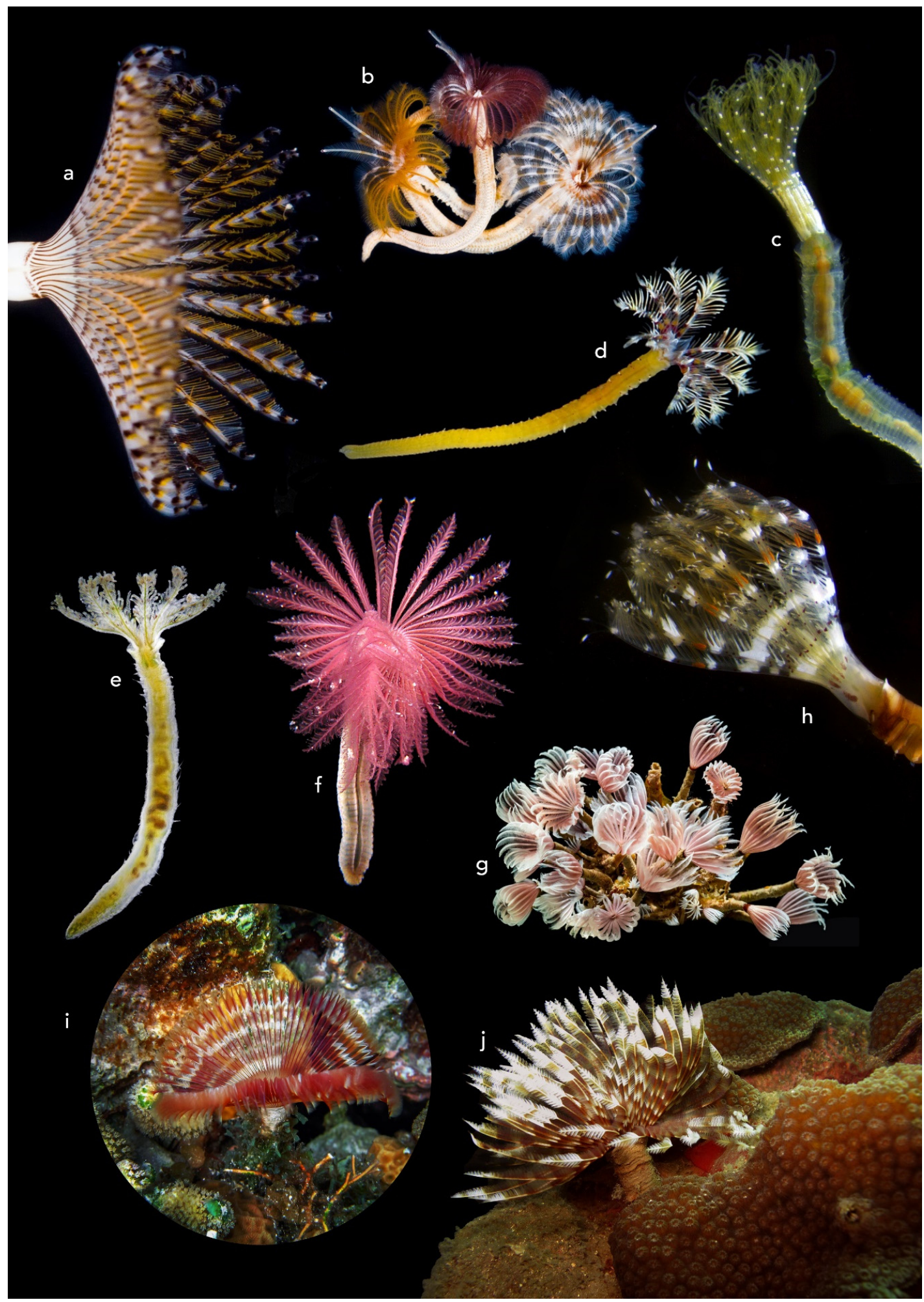

Figure 4. Some sabellid representatives showing a range of the diversity of forms found in the group. (a) Stylomma palmatum, Lizard Island, Australia; (b) Acromegalomma spp., Lizard Island, Australia; (c) Paradialychone ambigua, Lizard Island, Australia; (d) Pseudobranchiomma paraemersoni, São Paulo, Brazil; (e) Laonome xeprovala, Sea of Azov; (F) Branchiomma sp., Mexico; (g) Bispira brunnea, Caribbean; (h) Notaulax sp., Lizard Island, Australia; (i) Anamobaea orstedii., Mexico; (j) Sabellastarte magnifica, Mexico. ((a,b,g), by M. Bok; (e) by V. Syomin, $(\mathbf{i}, \mathbf{j})$ by H. Bahena). 
Table 3. Sabellid currently accepted genera that have gone through major or partial revisions and phylogenetic analyses (either considering morphological features, molecular data or both).

\begin{tabular}{|c|c|c|c|}
\hline Genera & Number of Species* & Revision & Phylogenetic Analyses \\
\hline $\begin{array}{l}\text { Acromegalomma Gil and Nishi, } \\
2017\end{array}$ & 38 & $\begin{array}{c}\text { Perkins 1984, Tovar-Hernández and } \\
\text { Salazar-Vallejo 2008; Capa and } \\
\text { Murray 2009; Tovar-Hernández and } \\
\text { Carrera-Parra 2011, Gil and Nishi } \\
2017\end{array}$ & $\begin{array}{l}\text { Capa and Murray 2009, } \\
\text { Tovar-Hernández and } \\
\text { Carrera-Parra } 2011\end{array}$ \\
\hline Amphicorina Claparède, 1864 & 46 & $\begin{array}{c}\text { Rouse } 1990 \text { (as Oriopsis), Cochrane } \\
2003\end{array}$ & Cochrane 2003 \\
\hline Amphiglena Claparède, 1864 & 14 & $\begin{array}{l}\text { Capa and Rouse 2007; Tilic et al. } \\
2019\end{array}$ & $\begin{array}{c}\text { Capa and Rouse 2007, Tilic } \\
\text { et al. } 2019\end{array}$ \\
\hline Anamobaea Krøyer, 1856 & 2 & Tovar-Hernández et al. 2020 & NO \\
\hline $\begin{array}{l}\text { Aracia Nogueira, Fitzhugh } \\
\text { and Rossi, } 2004\end{array}$ & 3 & $\begin{array}{l}\text { Nogueira et al. 2004; } \\
\text { Tovar-Hernández } 2014\end{array}$ & Nogueira et al. 2010 \\
\hline Bispira Krøyer, 1856 & 24 & $\begin{array}{c}\text { Knight-Jones and Perkins 1998; } \\
\text { Capa } 2008\end{array}$ & Capa 2008 \\
\hline Branchiomma Kölliker, 1859 & 30 & $\begin{array}{l}\text { Tovar-Hernández and Knight-Jones } \\
2006\end{array}$ & $\begin{array}{c}\text { Capa et al. 2013; del Pasqua } \\
\text { et al. } 2018\end{array}$ \\
\hline Caobangia Giard, 1893 & 7 & Jones 1974 & $\mathrm{NO}$ \\
\hline Chone Krøyer, 1856 & 20 & $\begin{array}{c}\text { Cochrane 2003, Tovar-Hernández } \\
\text { 2005, 2006, 2007a, b, c, } 2008\end{array}$ & Tovar-Hernández 2008 \\
\hline Claviramus Fitzhugh, 2002 & 5 & Fitzhugh 2002; Nishi et al. 2019 & $\mathrm{NO}$ \\
\hline Dialychone Claparède, 1869 & 19 & $\begin{array}{l}\text { Tovar-Hernández } 2008 \\
\text { Cochrane 2003, Giangrande and }\end{array}$ & Tovar-Hernández 2008 \\
\hline Euchone Malmgren, 1866 & 35 & $\begin{array}{l}\text { Licciano 2006, Giangrande et al. } \\
2017\end{array}$ & Cochrane 2003 \\
\hline $\begin{array}{l}\text { Euchoneira Licciano, } \\
\text { Giangrande and Gambi, } 2009\end{array}$ & 1 & Licciano et al. 2009 & Licciano et al. 2009 \\
\hline Eudistylia Bush, 1905 & 5 & Hartman 1938, Banse 1979 & $\mathrm{NO}$ \\
\hline Hypsicomus Grube, 1870 & 1 & Perkins 1984 & $\mathrm{NO}$ \\
\hline Jasmineira Langerhans, 1880 & 19 & $\begin{array}{l}\text { Cochrane 2003, Capa and Murray } \\
\qquad 2015\end{array}$ & Cochrane 2003 \\
\hline Laonome Malmgren, 1866 & 10 & $\begin{array}{l}\text { Fitzhugh 2002, Capa 2007, Bick et al. } \\
2018\end{array}$ & Capa 2007 \\
\hline Notaulax Tauber, 1879 & 26 & Perkins 1984 & NO \\
\hline $\begin{array}{c}\text { Paradialychone } \\
\text { Tovar-Hernández, } 2008\end{array}$ & 16 & Tovar-Hernández 2008 & Tovar-Hernández 2008 \\
\hline Parasabella Bush, 1905 & 29 & $\begin{array}{c}\text { Perkins 1984, Giangrande 1994, } \\
\text { Tovar-Hernández and Harris 2010, } \\
\text { Capa and Murray 2015b, Keppel } \\
\text { et al. } 2020\end{array}$ & Capa and Murray 2015b \\
\hline Perkinsiana Knight-Jones, 1983 & 16 & $\begin{array}{l}\text { Knight-Jones 1983, Giangrande and } \\
\text { Gambi 1997, Tovar-Hernández et al. } \\
2012\end{array}$ & $\mathrm{NO}$ \\
\hline Potamethus Chamberlin, 1919 & 11 & Knight-Jones 1983 & $\mathrm{NO}$ \\
\hline Potamilla Malmgren, 1866 & 10 & Knight-Jones 1983 & $\mathrm{NO}$ \\
\hline Potaspina Hartman, 1969 & 2 & Capa 2007 & Capa 2007 \\
\hline Pseudobranchiomma Jones, 1962 & 19 & $\begin{array}{l}\text { Knight-Jones 1994, Knight-Jones } \\
\text { and Giangrande } 2003\end{array}$ & Capa and Murray 2016 \\
\hline Pseudopotamilla Bush, 1904 & 23 & Knight-Jones et al. 2017 & Capa 2007 \\
\hline Sabella Linnaeus, 1767 & 39 & Knight-Jones and Perkins 1998 & $\mathrm{NO}$ \\
\hline Sabellastarte Krøyer, 1856 & 8 & Knight-Jones and Mackie 2003 & Capa et al. 2010 \\
\hline $\begin{array}{l}\text { Sabellomma Nogueira, } \\
\text { Fitzhugh and Rossi, } 2010\end{array}$ & 4 & $\begin{array}{c}\text { Nogueira et al. 2010, Capa and } \\
\text { Murray } 2015\end{array}$ & Nogueira et al. 2010 \\
\hline Stylomma Knight-Jones, 1997 & 2 & $\begin{array}{c}\text { Knight-Jones and Perkins 1998, } \\
\text { Capa } 2007\end{array}$ & Capa 2007 \\
\hline $\begin{array}{c}\text { Terebrasabella Fitzhugh and } \\
\text { Rouse, } 1999\end{array}$ & 3 & Murray and Rouse 2007 & Murray and Rouse 2007 \\
\hline
\end{tabular}


Phylogeny of Sabellidae has been largely assessed [2,64-70]. Monophyly of Acromegalomma, Amphiglena Claparède, 1864, Branchiomma Kölliker, 1859, Chone, Dialychone Claparède, 1869, Paradialychone Tovar-Hernández, 2008 and Pseudobranchiomma Jones, 1962) have been confirmed [68,71-74]. Members of the genera Chone, Dialychone and Paradialychone are still problematic due to their small size and because genera and species are delineated based on combination of features, such as details of uncini dentition (anterior and posterior abdominal chaetigers) and radiolar crown structures (lips and pinnular appendages) that are often difficult to interpret. As a result, the position of some species within either Dialychone, Paradialychone or Chone based on morphology is uncertain (e.g., P. ambigua Capa and Murray, 2015) and a molecular approach to this group is needed. The genera Bispira Krøyer, 1856 [2,69,74], Euchone [67,75,76] and Perkinsiana Knight-Jones, 1983 [68] appear to be paraphyletic, whereas monophyly of Laonome Malmgren, 1866, Parasabella Bush, 1905 and Sabellastarte Krøyer, 1856 should be assessed.

In the last two decades a number of sabellid genera have undergone major or partial taxonomic revisions (Table 3) that included morphological comparisons of congeners, as well as examination and re-description of types to detect potential synonyms or undescribed species. In a few of them, monophyly has been assessed through phylogenetic analyses of mainly morphological data.

\subsubsection{Serpulidae}

Monophyly of Serpulidae is supported by the presence of calcareous tubes with complex ultrastructures, distinct from the simple structure found in calcareous tubes of the unique sabellid Glomerula piloseta (Perkins, 1991). The serpulid thorax is surrounded by the thoracic membranes, which are absent in sabellids and fabriciids. Most serpulids have an operculum (or several), a modification of the distal part of a radiole, acting as a plug when animals hide in their tubes (Table 1, Figure 5).

The first formal phylogenetic analysis based on morphological data [43] recovered monophyletic Spirorbinae (as sister group to Serpulinae, including Chitinopoma Levinsen, 1884, Crucigera Benedict, 1887, Serpula Linnaeus, 1758, Hydroides Gunnerus, 1768, Ficopomatus Southern, 1921, Galeolaria Lamarck, 1818, Spirobranchus Blainville, 1818) and paraphyletic Filograninae (Filograna Berkeley, 1835, Microprotula Uchida, 1978, Protula Risso, 1826). Phylogenetic studies using DNA data inferred two major clades within Serpulidae, e.g., [45-49]. The clade A comprised two clades: the Serpula-Crucigera-Hydroides (Clade AI 'Serpula-group') and the Spirobranchus-Ficopomatus-Ditrupa (Clade AII 'Spirobranchus-group'). The Clade B included a monophyletic Spirorbinae as sister group to the Protis-Protula-Vermiliopsis-Chitinopoma (clade BI 'Protula-group'). Position of serpulin genera, such as Vermiliopsis and Chitinopoma within clade BI along with typical filogranins, made both traditional Filograninae and Serpulidae paraphyletic.

Within Clade A, further assessment of AI 'Serpula-group' (Serpula, Crucigera, Hydroides) [77] supported monophyly of Hydroides, but Serpula was recovered as paraphyletic basal grade and Crucigera was polyphyletic. Later studies assessed relationships within the largest serpulid genus Hydroides [78-80]. Within AII 'Spirobranchus-group' several studies examined relationships within the genus Spirobranchus [81-84] and demonstrated sister group relationship between brackish-water genus Ficopomatus and freshwater monotypic Marifugia Absolon and Hrabĕ, 1930 [46]. 


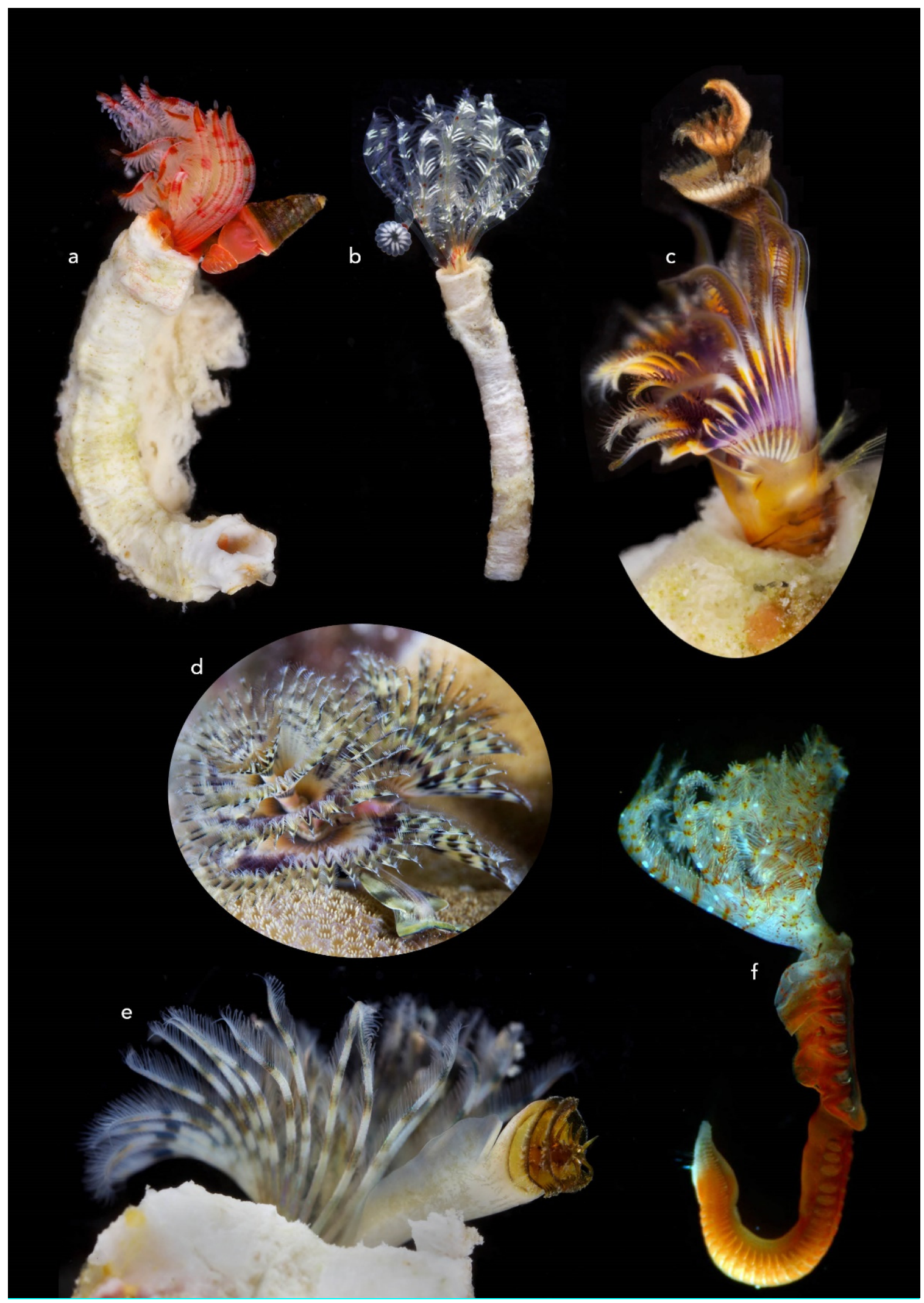

Figure 5. Diversity within Serpulidae. (a) Vermiliopsis glandigera/pygidialis-complex sp., Lizard Island, Australia; (b) Serpula sp., Lizard Island, Australia; (c) Hydroides lirs, Lizard Island, Australia (d) Spirobranchus corniculatus, Lizard Island, Australia; (e) Pomatostegus actinoceras, Lizard Island, Australia.; (f) Protula sp., Lizard Island, Australia. ((a-e) by A. Semenov, (f) by G. Rouse). 
Within clade B, studies focused on Spirorbinae, classification of which is based [85] on the six distinct types of brooding, two opercular (Pileolariinis and Januini) and four tubular (Romanchellini, Paralaeospirini, Circeini, Spirorbini). It has been repeatedly argued that tube incubation precedes opercular brooding [85-88], but Thorp and Segrove [89] advocated for an ancestral opercular incubation. Results of the first morphology-based phylogenetic analysis of spirorbins [44] confirmed the ancestry of tube brooding, but suggested that the opercular brooding arose once and the brooding cup of Januini is a simplification of the brooding structure of Pileolariini. Another analysis of morphological data [90] confirmed that opercular brooding is derived, but suggested that the two types arose independently. No molecular spirorbin phylogeny is available to test this arrangement. As neither traditional Serpulinae, nor Filograninae are monophyletic, re-classification based on a comprehensive integrative analysis and re-formulation of the subfamily diagnoses are needed. Meanwhile Spirorbinae is accepted as nested within Serpulidae, but other serpulid genera are not assigned into subfamilies. Most serpulid genera have not been revised (Table 4).

Table 4. Serpulid currently accepted genera that have undergone major or partial revisions and phylogenetic analyses (using morphological features, molecular data or both).

\begin{tabular}{|c|c|c|c|}
\hline Genera & Number of Species * & Revision & Phylogenetic Analyses \\
\hline $\begin{array}{c}\text { Bathyditrupa Kupriyanova, } \\
1993\end{array}$ & 1 & Kupriyanova and Ippolitov 2015 & $\mathrm{NO}$ \\
\hline Bathyvermilia Zibrowius, 1973 & 7 & Zibrowius 1973 & $\mathrm{NO}$ \\
\hline $\begin{array}{l}\text { Crucigera Benedict, } 1887 \\
\text { Ditrupa Berkeley, } 1835\end{array}$ & 5 & $\begin{array}{c}\text { ten Hove and Jansen-Jacobs } 1984 \\
\text { ten Hove and Smith } 1990\end{array}$ & $\begin{array}{l}\text { Kupriyanova et al. } 2008 \\
\text { NO }\end{array}$ \\
\hline Ficopomatus Southern, 1921 & 6 & ten Hove and Weerdenburg 1978 & $\begin{array}{c}\text { Kupriyanova et al. 2009; Styan } \\
\text { et al. } 2017\end{array}$ \\
\hline Galeolaria Lamarck, 1818 & 3 & $\mathrm{NO}$ & $\begin{array}{l}\text { Halt et al. 2009; Smith et al. } \\
2012\end{array}$ \\
\hline Hydroides Gunnerus, 1768 & 99 & $\begin{array}{l}\text { Bastida-Zavala and ten Hove 2002, } \\
\text { 2003; Sun et al. 2015; Sun et al. } 2018\end{array}$ & Sun et al. 2018 \\
\hline $\begin{array}{c}\text { Laminatubus ten Hove and } \\
\text { Zibrowius, } 1986\end{array}$ & 3 & Rouse and Kupriyanova 2021 & Rouse and Kupriyanova 2021 \\
\hline $\begin{array}{c}\text { Marifugia Absolon and Hrabe, } \\
1930\end{array}$ & 1 & Kupriyanova et al. 2009 & Kupriyanova et al. 2009 \\
\hline Metavermilia Bush, 1905 & 15 & Zibrowius 1971; Nishi et al. 2007 & $\mathrm{NO}$ \\
\hline $\begin{array}{c}\text { Pseudochitinopoma Zibrowius, } \\
1969\end{array}$ & 5 & Kupriyanova et al. 2012 & $\mathrm{NO}$ \\
\hline Pyrgopolon de Montfort, 1808 & 3 & ten Hove 1973 & $\mathrm{NO}$ \\
\hline Serpula Linnaeus, 1758 & 30 & $\mathrm{NO}$ & Kupriyanova et al. 2008 \\
\hline $\begin{array}{c}\text { Spirobranchus de Blainville, } \\
1818\end{array}$ & 36 & ten Hove 1970 & $\begin{array}{l}\text { Willette et al. 2015; Perry et al. } \\
\text { 2019; Pazoki et al. } 2020\end{array}$ \\
\hline Spiraserpula Regenhardt, 1961 & 18 & Pillai and ten Hove 1994 & NO \\
\hline Spirodiscus Fauvel, 1909 & 2 & $\begin{array}{l}\text { Kupriyanova and Nishi 2011, } \\
\text { Kupriyanova and Ippolitov } 2015\end{array}$ & $\mathrm{NO}$ \\
\hline
\end{tabular}

* Excluding subspecies.

\subsection{Diversity and Species Discovery}

3.2.1. Number of Genera and Species

Within Fabriciidae, 17 genera, 82 species and four subspecies are currently considered valid (Table S1). This revised dataset differs from that of Pamungkas et al. [91], who listed 21 genera and 91 species, but erroneously counted the genera Eriographis Grube, 1850, Leiobranchus Quatrefages, 1850, Leptochone Claparède, 1870 and Tuba Renier, 1804, all of them already synonymised with the sabellid genus Myxicola (Fitzhugh 1989). Discrepancy in the number of species is due to synonymisations and new combinations, as recently updated in WoRMS. 
The first fabriciid genus, Fabricia Blainville, 1828, was established to accommodate Tubularia stellaria Müller, 1774, a species with only 12 chaetigers and smaller than the sabellids described at that time [90]. In mid-19th century the genus Manayunkia was erected and Fabriciola was established only in the 20th century. In the second half of the 20th century, 11 genera were established and four genera were erected at the beginning of the 21st century (Figure 6). It is remarkable that among the 17 currently valid Fabriciidae genera, eight were established by Fitzhugh alone (Bansella Fitzhugh, 2010, Brifacia Fitzhugh, 1998, Fabricinuda Fitzhugh, 1990a, Novafabricia Fitzhugh, 1990b, Parafabricia Fitzhugh, 1992, Pseudoaugeneriella, Pseudofabriciola and Raficiba Fitzhugh, 2001) or with collaborators (Echinofabricia and Rubifabriciola) [27].

According to Pamungkas et al. [91], whose data were collected in 2016, Sabellidae comprises 42 genera and 493 valid species. Since 2016, 20 new species have been described [74,92-103] and a new monotypic genus Euchonoides Magalhães, Bailey-Brock and Tovar-Hernández, 2020 was established. After the WoRMS database has been updated (see Materials and Methods section), the current count is 42 genera and 512 valid species in Sabellidae (Table S2). The first described genus was Sabella Linnaeus, 1767. From 1801 to 1850 only the genus Myxicola was established (Koch in [104]). The second half of the 19th century was a productive period, with 15 genera established. In the 20th century, six genera were erected in the first half, and nine in the second. Finally, from 2001, eight genera have been erected (Figure 6).

According to Pamungkas et al. [91], Serpulidae comprises 576 species in 77 genera, as they mistakenly included several fossil taxon names in the count of extant species. Serpulidae now comprises 562 species in 69 genera, which includes 48 genera with 374 extant species of Serpulinae sensu lato and 23 genera with 188 extant species of Spirorbinae (Table S3). These numbers, however, do not include those of fossil taxa (180 species, in 53 genera), not considered here. Out of 69 species of the genus Spirorbis Daudin, 1800, 46 were described before Bailey [85] re-classified spirorbins according to the incubation methods and never revised, so some of them upon a revision can be re-assigned to other genera.

The first serpulids described within the newly erected genus Serpula by Linnaeus [105] were Spirobranchus triqueter (non Linnaeus, sensu Fabricius, 1780), as S. triquetra, Spirorbis spirorbis (Linnaeus, 1758), as S. spirorbis, and Circeis spirillum (Linnaeus, 1758), as S. spirillum. Serpula vermicularis Linnaeus, 1767, the type species of the type genus, was described only nine years later. The monotypic genus Hydroides, with $H$. norvegica Gunnerus, 1768, was the second serpulid genus to be described in the 18th century. In the 19th century, 28 genera, eight spirorbins and 20 serpulins, were described. In 1900-1959, 22 genera (including three spirorbin) were described, while 48 genera were erected in the second half of the 20th century (1960-2000). Finally, from 2001, four genera, including three serpulin and one spirorbin, have been erected [49,106,107] (Figure 6).

\subsubsection{Taxonomists and Species Discovery}

Kirk Fitzhugh is the most productive author in terms of the number of discovered fabriciid species, with 27 species described alone and four in collaborations. Other authorities of fabriciid species include Karl Banse, Gesa Hartmann-Schröder and Greg Rouse, with six species described by each, all as single authors (Table S1).

The most prolific author in terms of sabellid species discovery is Adolph Eduard Grube, who described 40 species before 1881. Other productive taxonomists are María Ana Tovar-Hernández (42 species: 36 as first or single author, 6 as co-author); María Capa (29 species, all as first author or alone), Adriana Giangrande (29 species: 14 as first author or alone, and 15 as co-author), Olga Hartman (18 species) and Gesa Hartmann-Schröder (16 species) (Table S2).

The most productive serpulid taxonomist is Harry ten Hove who so far described 49 species, including seven alone. Gottfried Pillai described 46 species, including 31 species described alone and 15 in collaboration with ten Hove. Phyllis and Wynn Knight-Jones described 41 species, mostly spirorbins. Katherine Bush described 33 species, includ- 
ing 25 alone. Helmut Zibrowius described 31 species, including 29 alone and Elena Kupriyanova authored 29 species, including eight alone. Other productive serpulid taxonomists (over 15 species described) are Minoru Imajima (21 species) and Alexander Rzhavsky (17 species, mostly spirorbins) (Table S3).

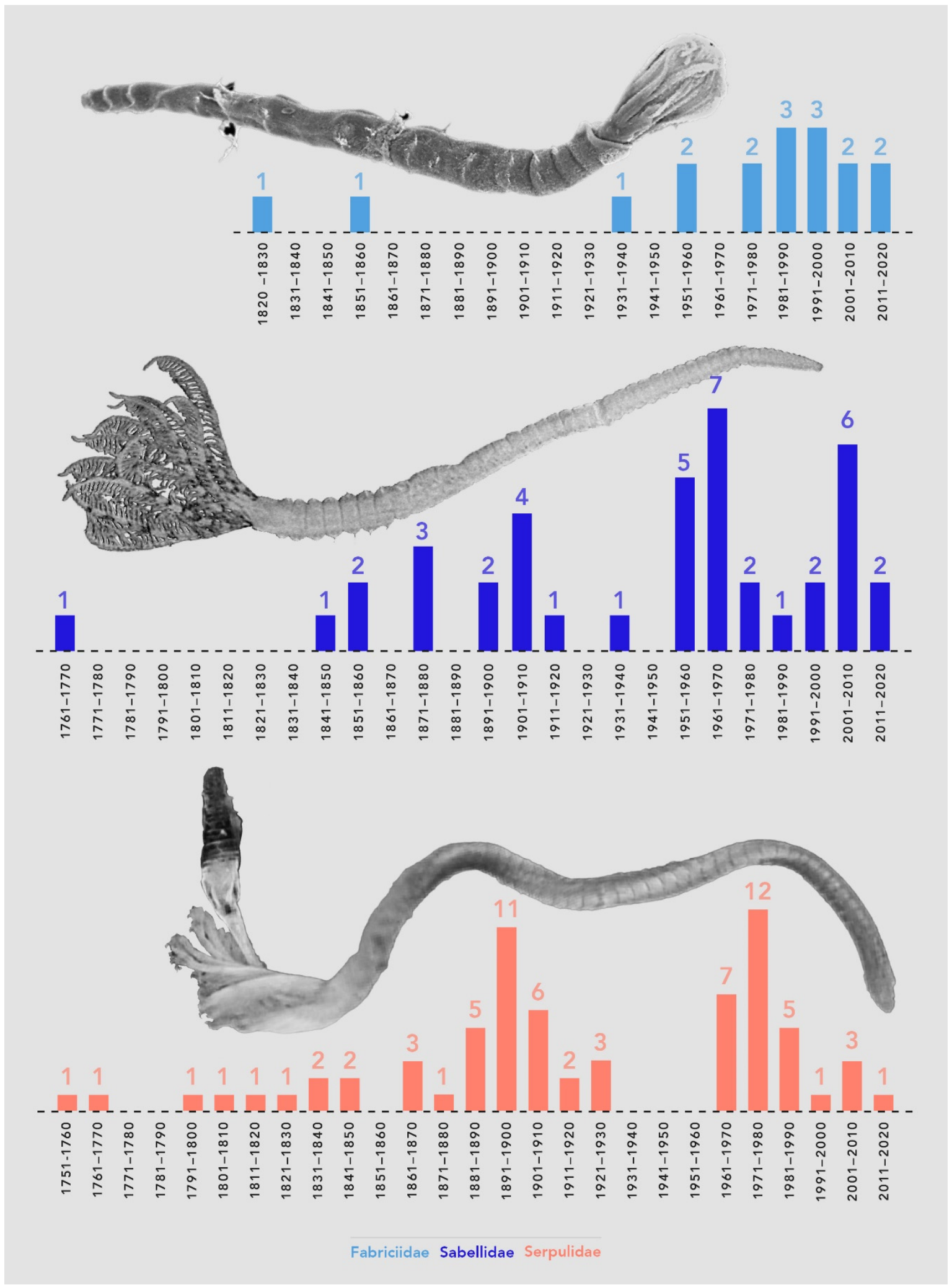

Figure 6. Number of genera erected each decade in Fabriciidae, Sabellidae, and Serpulidae. 


\subsubsection{Identification Keys, Diversity Assessments, and Recent Regional Taxonomic Studies}

The key to all polychaete genera by Fauchald [12] includes all sabellids and serpulids considered valid at the time, but it is outdated and not recommended for taxonomic work anymore. A key to Fabriciidae genera recognized until 1998 was provided by Fitzhugh [57]. In that study, the currently accepted Echinofabricia was named Genus A. The most recently updated key to all fabriciid genera is that by Tovar-Hernández and Fitzhugh, in press. The keys to Sabellidae genera were provided by Fitzhugh [42], TovarHernández [108] and most recently Tovar-Hernández and Fitzhugh [109]. The review by ten Hove and Kupriyanova [110] includes diagnoses and a key to all serpulid genera (excluding spirorbins) valid at the time.

Revision of literature reveals that intensive fieldwork and continuous taxonomic studies by a single scientist in a specific area have had a great impact in biodiversity knowledge of a region. However, large geographic regions have been scarcely studied, not only in difficult to access deep-sea environments, but even in the intertidal and subtidal zone either because not enough work has been put into taxonomic surveys, or members of Sabellida were not among targeted groups. It is expected that our understanding of species diversity will improve after efforts (financial, logistical, technological and taxonomic expertise) are devoted to fill those gaps. Herein, information about the most recent regional surveys and taxonomic revisions is provided, and the number of species described in these areas given as a rough approximation of their biodiversity knowledge.

The regions with the overall highest number of type localities of described species are the coastal areas of Europe, both coasts of North America, and Central and Western Indo-Pacific, while the areas with lower number of original descriptions are the majority of Africa, South America, as well as Tropical Eastern Pacific and Eastern Indo-Pacific (Figure 7).

The current state of biodiversity knowledge and a summary of the most recent (defined here as last 20 years) comprehensive checklists, faunistic and taxonomic regional studies (excluding single species descriptions) are organised below by marine realms. References to main comprehensive taxonomic studies are provided as recommendations for getting started with faunas of each realm.

Arctic

This realm covers the Arctic Ocean down to Newfoundland in the western Atlantic, including the northern half of Iceland, northern Russia, from the White Sea to the Bering strait, and all northern Alaska and Canada. One fabriciid, 16 sabellid species, and 16 serpulids have been described from the Arctic, most of them from the Western sector of the Arctic Ocean (Figure 7, Tables S1-S3). Knight-Jones et al. [111] reviewed species of Pseudopotamilla from Iceland, Greenland and the Canadian Arctic. Jirkov's book [112] on Arctic polychaetes, that includes diagnoses, illustrations, and keys to sabellids (including fabriciids) and serpulids (including spirorbins), as well as the recent comprehensive illustrated revisions with taxonomic keys to all Arctic Serpulidae (including Spirorbinae) by Rzhavsky et al. $[113,114]$ are recommended for studies in this region.

\section{Temperate Northern Atlantic}

This realm is delimited in the north with the Arctic realm, and in the south reaches the coasts of Florida, including the northern half of the Gulf of Mexico, and is delimited in the east by the Cape Verde archipelago and the coasts of Mauritania. It also includes the Mediterranean and the Black Sea. Sixteen fabriciids, 124 sabellids, and 108 serpulids have been described from this realm (Figure 7). Of these, one fabriciid, 18 sabellid, and 12 serpulid species were from the Western coasts of the Atlantic Ocean and three sabellids were from northwest Africa. All the rest were described from European waters and the Mediterranean (Tables S1-S3). 


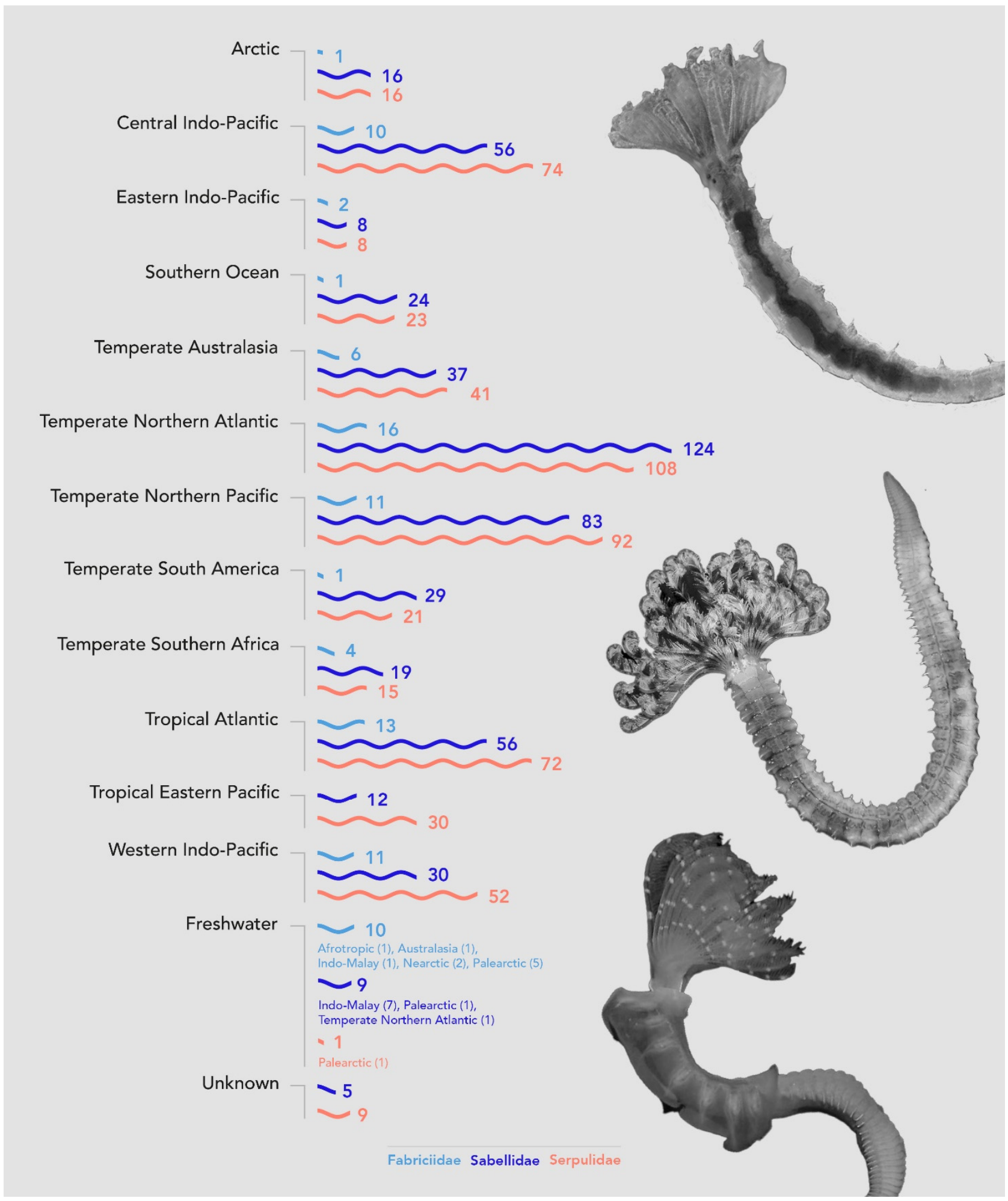

Figure 7. Number of species described for each marine realm (in alphabetical order, according to Spalding et al. [31]) and Udvardy 1975 for limnic realms.

The book by Fauvel on sedentary polychaetes of France [115] provide descriptions and illustrations of the common species of the north eastern Atlantic and western Mediterranean and is still been widely used despite being outdated. Relatively more updated sources of serpulid diversity data in the Mediterranean are books by Zibrowius [116] and Bianchi [117] that include keys, descriptions and illustrations. The illustrated key 
by Knight-Jones [118] to the British Isles and North-West Europe is recommended as an initial source of data on Sabellidae, Fabriciidae and Serpulidae. The incoming book on Fauna Ibérica includes chapters on Fabriciidae and Sabellidae and will be a new standard reference for the region $[119,120]$.

Despite the overall high number of species described from this region, only a few taxonomic and faunistic studies have been carried out on Sabellida in the last 20 years in the Atlantic provinces of this realm. In particular, fabriciids were studied by Bick [121], species of Euchone by Bick and Randel [122], Chone by Tovar-Hernández et al. [123,124] and Pseudopotamilla by Knight-Jones et al. [111]. However, the notable exception has been the Mediterranean, where much taxonomic activity, with particular emphasis on introduced species, has taken place recently. Some representative contributions dealing with Mediterranean fanworms include those by Çinar (on serpulids [125], on nonindigenous species [126]), the general annelid checklist of polychaetes from Turkey [127], Selim et al. (on Dialychone and Paradialychone [128]), Giangrande et al. (sabellids of the Ionian Sea [129], on Acromegalomma [130]), the general papers on annelid diversity of the Adriatic Sea [131,132] and the fabriciids and sabellids of the Adriatic [133], the checklist of Iberian species [134] and the most recent one by Tilic et al. [103] dealing with Amphiglena. A checklist of the polychaetes from the Black Sea includes three fabriciids, six sabellids, and 11 serpulids [135].

\section{Temperate Northern Pacific}

The western side of this realm is demarcated by the Bering Strait in the north, and an imaginary line from Taiwan to the south of Baja California Peninsula, in the south. The number of fabriciids described in this realm is 11, eight of them from the Eastern side (Table S1). The number of described sabellids is 83,37 of which from the Western side, and 46 from the Eastern side (Table S2). Out of 92 serpulid species described from this region, 54 are from the western side (Table S3).

The catalogue of sedentary polychaetes from California [136], still widely used for the region, is outdated and is not recommended. The monograph of polychaetes of the Russian Far-East [136] and its English translation [137] that remains the main source of keys and information on polychaetes of the region, including Sabellida, is also outdated and thus should be used with caution.The revision of spirorbins from the east Pacific coast [137] is still the most recent source of information on this group.

The most recent literature-based annotated checklist of polychaetes from Pacific coasts of Russia lists 37 sabellids (including fabriciids) and 40 serpulids [138]. Sabellids from Japan were recently reported by Nishi et al. [95,139] and Yoshihara et al. [140]. Taxonomic studies on serpulids of Japan are summarized in the book by Imajima [141] that provides an illustrated key to 55 species of Serpulidae, but does not include sabellids. The most recent account of Chinese polychaetes [142] provides diagnoses and keys to 64 species of sabellids and 98 serpulid species, and is recommended as a source of biodiversity data and taxonomic keys for China. The complementary revision [143] includes a checklist of most annelid groups from the South China Sea, and lists three fabriciid, 33 sabellid and 72 serpulid species. Recent revisionary studies, including taxonomic keys, from the Pacific coast of North America have reported seven species of sabellids and more than 40 serpulids in the following contributions dealing with species of Hydroides from Northern Mexico [144], serpulids from the Eastern Pacific [145,146], sabellids and serpulids from northern Mexico [147,148], and sabellid Acromegalomma [149] and Notaulax species also from Northern Mexico [101].

\section{Tropical Atlantic}

This realm is delimited in the north by the Temperate Northern Atlantic realm and in the south by an imaginary line from Rio de Janeiro in the west to the southern border of Angola in the east. It also includes the southern half of the Gulf of Mexico and the Caribbean. Thirteen fabriciid species have been described from western side of the realm, 
specifically from the Caribbean, and none from the eastern Atlantic (Table S1). Out of 56 sabellids described in the region, only one came from the African coasts (Table S2) and of the 72 serpulids, only 10 were described from Africa (Table S3).

Zibrowius [150] made the first study on Brazilian serpulids. Other recommended taxonomic studies of serpulids (other than Hydroides) of Caribbean are those by ten Hove [151-154].

Recent studies of the Caribbean fanworms included those describing fabriciids [27,155]; revisions of species in Chone [156] and Branchiomma [157]; records and new species of sabellids [155,158]; and selected serpulids, such as Hydroides [159], Serpula and Spiraserpula [160]. The tropical coasts of South America have been scarcely studied. The checklist of polychaetes of Brazilian Tropical Atlantic region reports 11 sabellid and 24 serpulid species for the area [161-164], with no fabriciids registered so far. However, several of those are records of species described from Europe, North America and South Africa, demanding further study. Additionally, Amaral et al. [163] checklist treated many already synonymised species as valid.

The illustrated key of Sabellidae and Fabriciidae by Tovar-Hernández and Fitzhugh [105] includes all species currently known for the Caribbean, whereas Caribbean Serpulidae are available in [165].

\section{Western Indo-Pacific}

This large realm covers most of East coast of Africa, Madagascar, Arabian (Persian) Gulf, the Red Sea, shelf of Bay of Bengal and Andaman Sea. The number of species described in this realm is 93, including 11 fabriciids, 30 sabellids, and 52 serpulids (Figure 7, Tables S1-S3). Out of 52 serpulids, only eight were described from African coasts.

An influential book on Indian polychaetes [166], unfortunately, lists European species (and even illustrates specimens collected in France) and therefore, is not recommended as an identification tool beyond the generic level. The most recent checklist by Sivadas and Carvalho [167] includes two fabriciids, 11 sabellids and 34 serpulids from India and critically evaluated annelid species richness in the region, stressing that native species diversity of India is severely underestimated. The relatively large number of serpulids described from Sri Lanka is due to the intense work of Pillai $[40,168,169]$. These publications still remain as the only source of faunal information for that region.

An annotated literature-based checklist by Wehe and Fiege [170] is the best compilation of annelid diversity in the area surrounding the Arabian Peninsula. The most recent checklist of intertidal polychaetes of Kuwait by Al-Kadari et al. [171], based on newly collected material, reported seven species of Sabellidae and 12 Serpulidae. A monograph on Serpulidae from the Suez Canal by Ben-Eliahu and ten Hove [172] included 16 species. In the Red Sea, Perry at al. [81] reviewed of serpulids of the genus Spirobranchus and sabellids have not been studied since Knight-Jones [173].

\section{Central Indo-Pacific}

This realm comprising the largest number of ecoregions (40) includes part of the coast of South-East Asia, from Taiwan to Malaysia, down to Tropical Australia from Coral Bay, in the West, to Brisbane, in the East. The eastern boundary of this region is delimited by an imaginary line from Fiji up to the south of Japan. The realm includes the Coral Triangle recognized as the global centre of marine biodiversity [174], and fanworms are also diverse in this region. Ten fabriciids, 56 sabellids, and 74 serpulids have been described from this realm (Figure 7), mainly from the Philippines and tropical Australia (Tables S1-S3). Other than newly described species, 78 species of Sabellidae have been reported only from the Gulf of Thailand, Indonesian Archipelago and the Philippine Seas [98,169], and at least 11 taxa are awaiting formal description $[175,176]$. Serpulidae from Hong Kong were most recently revised by Sun et al. [177], who provided illustrations, diagnoses and taxonomic keys. Tropical Australian sabellids belonging to 12 genera have been documented in a series of recent studies $[68,69,72-74,178]$. Serpulids from Kimberley (Western Australia) were revised by Pillai [106] and those from Lizard Island (Queensland) by Kupriyanova et al. [179], whereas the revision of the genus Hydroides in Australia [180] 
includes both tropical and temperate species. The most comprehensive treatment of Australian sabellids and serpulids is still the interactive key by Wilson et al. [181], but it is outdated in the light of the recent studies. The digital guide $[182,183]$ allows distinguishing 38 native and non-indigenous species of Serpulidae and 14 Sabellidae from Australia, and includes a glossary with main diagnostic features for members of both groups.

\section{Eastern Indo-Pacific}

This small in terms of the coastline length Pacific realm includes Hawaii, Marshall, Gilbert and Ellis Islands, Central and Southeast Polynesia, Marquesas, Eastern Island, and the shelf around them. It hosts type localities of 18 fanworms, including two fabriciids, eight sabellids, and eight serpulids (Figure 7, Tables S1-S3).

Fauna of this realm is poorly known beyond that of Hawaii. Out of eight serpulids described from this realm, five were described from Hawaii. The latest studies include those on serpulids of Hawaii (Hydroides [140], a key and records excluding spirorbins [145], records of 16 species with a key [142], and serpulids from Cross Seamounts in the Hawaiian chain [184]. Out of eight sabellids, five were described from Hawaii, and two species of Branchiomma were reported most recently [185]. A recent study of serpulids from atolls of Marshall Islands [186] reported 29 serpulids (including spirorbins). Small number of publications dealing with members of Sabellida highlights the need for taxonomic work in the area.

\section{Tropical Eastern Pacific}

This realm is delimited in the North by the Cape San Lucas, Baja California, by the northern border of Peru in the South and includes the Galapagos Islands in the West. No fabriciids have been described in this region (Table S1) and the number of described sabellids is 12, five of them originally reported from coast of Panama and the rest from further north (Figure 7, Table S2). The number of described serpulids is 30, most of them from Galapagos, Panama and Mexico (Figure 7, Table S3).

Recent studies of Sabellida from the region include those dedicated to Panamanian sabellids [187], some Acromegalomma [149] and Chone [124], and those focused on sabellids and serpulids from Mexico $[145,148,188]$. Three sabellids and two serpulid species introduced in the Galapagos Islands were reported by Keppel et al. [189].

\section{Temperate South America}

The realm covers both Pacific and Atlantic coasts of South America, from Peru to Rio de Janeiro, respectively. Only one fabriciid was described from this region (Table S1). Twenty-nine sabellids have been described (Figure 7), mainly from Chile and Argentina (Table S2), and 21 serpulids were described at a variety of localities from Brazil to Peru (Figure 7, Table S3).

The publication by Zibrowius [150] remains the most comprehensive study on Brazilian serpulids in both Tropical Atlantic and Temperate South America realms. More recent publications reported three species of fabriciids, 29 of sabellids and 22 species of serpulids for the Brazilian part of the Temperate South America realm [163] and 27 species of serpulids and 17 sabellids for Argentina [190]. Tovar-Hernández et al. [99] studied sabellids mainly from Argentina and Chile. A key to Sabellidae and Serpulidae from continental Chile is available in [191].

\section{Temperate South Africa}

This realm includes the coastline of Namibia and South Africa as well as Amsterdam and St. Paul Islands. It hosts type localities of 38 species of Sabellida, including four fabriciids, 19 sabellids and 15 serpulids (Figure 7, Tables S1-S3). Of these, 30 have been described in the littoral zone in South Africa, indicating that less taxonomic effort has been devoted to other areas within this region. The recent papers re-described two serpulid species based on type material (e.g., [192,193]. 
Although South African polychaetes, including fanworms, were summarized in the influential book by Day [194], most of Sabellida included in the monograph are 'cosmopolitan species' with European type localities (e.g., of 27 serpulids only six have type localities in South Africa), so native Sabellida species diversity is severely underestimated. Spirorbins from South Africa have not been reviewed since studies of Knight-Jones [195] and Knight-Jones and Knight-Jones [196].

\section{Temperate Australasia}

The realm includes coasts of Southern Australia and New Zealand hosting type localities of 86 species of Sabellida. This number includes six fabriciids from Australia (Table S1), 37 sabellids ( 28 described from the Australia and nine from New Zealand (Table S2) and 41 serpulids (28 from Australia and 15 from New Zealand, Table S3) (Figure 7).

Spirorbins from southern Australia have not been studied since they were reviewed by Knight-Jones et al. [197]. In New Zealand, spirorbins were studied by Vine [198], who reported 24 species, nine of them new to science, while a list of sabellids and serpulids was provided by Glasby and Read [199].

Sabellids from Australian temperate waters have been well documented in a series of recent papers $[68,69,72-74,200-202]$ along with records of temperate species. Most recent papers on temperate Serpulidae are Sun et al. [203] and Styan et al. [204], whereas the Australian Hydroides revision [180] also includes temperate species.

\section{Southern Ocean}

This large realm covers coasts of Antarctica and sub-Antarctic Islands. It hosts type localities of a single fabriciid, 24 sabellid and 23 serpulid species (six serpulins and 17 spirorbins) (Figure 7, Tables S1-S3). Many of these species were discovered and described as a result of Antarctic expeditions of the 19th and early 20th century (e.g., [205-210]).

The most recent contributions from the region are descriptions of two spirorbin species from Kerguelen and Bouvet Islands [211]; species of Perkinsiana [212] and reports of 19 still undescribed sabellids from Falkland Islands [213],demonstrating the underestimated diversity. There is no contribution summarizing Sabellida species diversity of this region.

\subsection{Diagnostic Characters and Techniques Used for Species Discrimination}

Most species within Sabellida are characterised by a unique combination of morphological features. The most useful morphological characters used for Sabellidae species identification are summarised in Capa et al. [24]; for Fabriciidae, see Bick [4]; for Serpulidae, see ten Hove and Kupriyanova [110] and Kupriyanova et al. [214]. Since detailed information is provided in these thorough revisions, only succinct identification guidelines are given below for each family.

\subsubsection{Shortcuts to Identification of Fabriciidae}

The small body size (most species are less than $5 \mathrm{~mm}$ long) and the absence of significant diagnostic characters make the identification of Fabriciidae difficult. All fabriciid species possess a radiolar crown with three pairs of radioles (Figure $8 \mathrm{a}-\mathrm{c}$ ). The branches are formed by successive longitudinal splitting of the radioles. The symmetrical branching of the radioles leads to bi-pectinated radioles, as found in most genera (Figure 8c), whereas pectinated radioles result in asymmetrical branching (Figure 8b), as in Manayunkia and Monroika only [4]. Ventral filamentous appendages, present in some genera, are associated with the radiolar crown (Figure $8 \mathrm{~b}$ ). These appendages have been described as nonvascularized (e.g., in all species of Fabriciola, Pseudofabricia Cantone, 1972 and Rubifabriciola) or vascularized (e.g., in all species of Augeneriella, Echinofabricia, Manayunkia, Monroika and Pseudoaugeneriella, and also some species of Fabricinuda and Pseudofabriciola) [57]. These appendages are branched only among species of Augeneriella. 


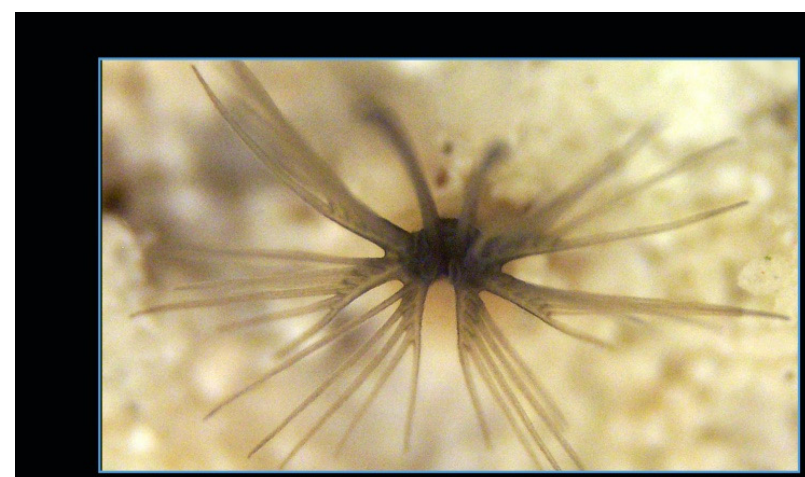

b

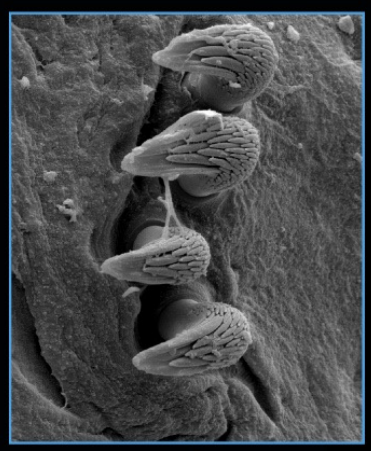

d

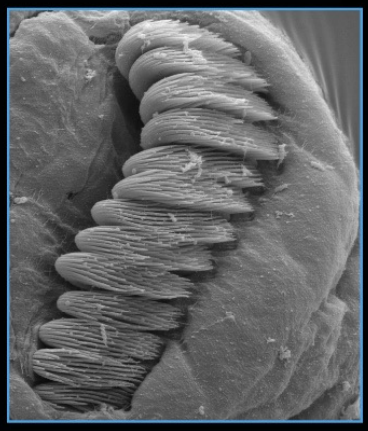

h

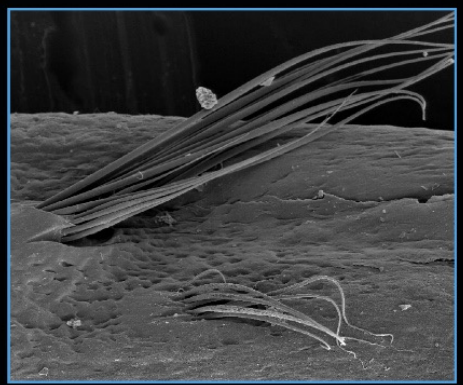

k

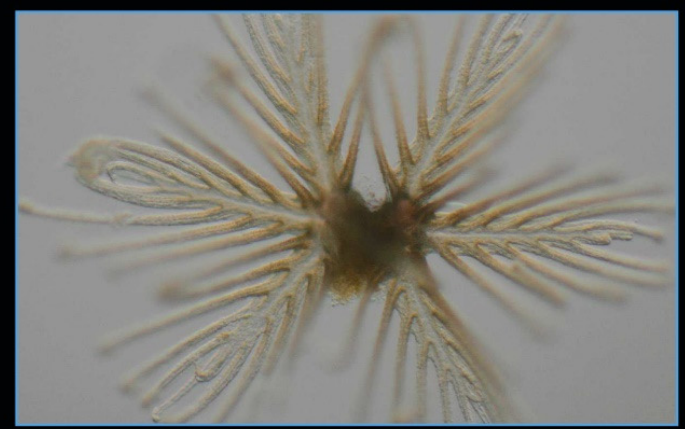

C

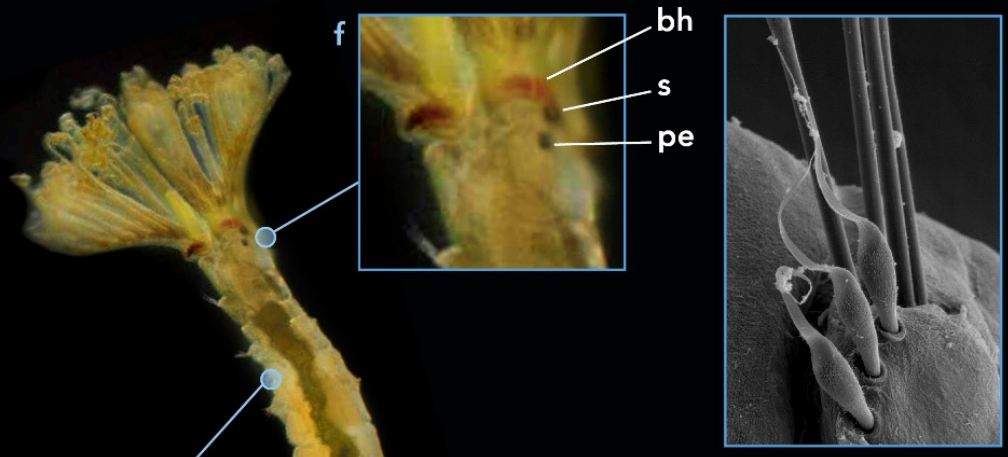

g

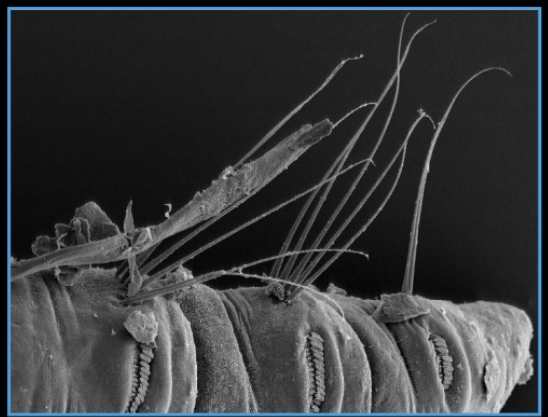

j

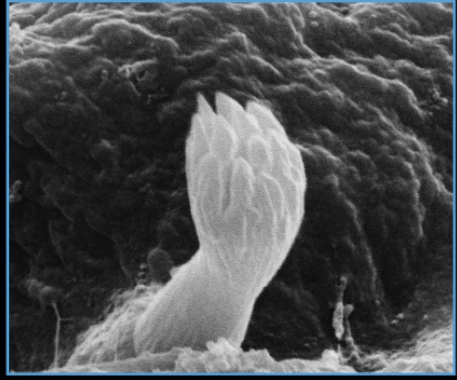

m

Figure 8. Main diagnostic characters for members of Fabriciidae. (a) Fabricia stellaris, dorsal view; (b) Pectinated radiolar branching pattern, Manayunkia athalassia; (c) Bi-pectinated radiolar branching pattern, F. stellaris; (d) Thoracic uncini of Manayunkia zenkewitschii; (e) Gamete bearing region in thorax; (f) Branchial heart (bh), spermathecal (s) and peristomial eye (pe), in this order; (g) Thoracic chaetae, M. athalassia; (h) Abdominal uncini, Pseudoaugeneriella nigra; (i) Pygidial eye (py); (j) Abdominal chaetae, M. athalassia; (k) Thoracic transitional chaetae (below), Manayunkia godlewskii; (l) Chaetal inversion, $M$. athalassia; (m) Abdominal pin-ead chaeta, Rubifabriciola tonerella. ((a,c) by A. Dietrich; (b) by G. Christie). 
Peristomial eyes (Figure 8f) are developed among most species of Fabriciidae, black in most fabriciids, or red, as in Echinofabricia and Rubifabriciola [27].

The presence of thoracic pseudospatulate and transitional (=pilose, after Jones 1974) chaetae is of taxonomic significance [4] (Figure 8g,k). However, the distribution of pseudospatulate chaetae is not consistent within the genera. These chaetae occur on chaetigers 2-5 (some Manayunkia species), 2-8 (Raficiba barryi Fitzhugh, 2001), 3-5 (Monroika africana and most Novafabricia species), 3-6 (Pseudoaugeneriella, some species of Augeneriella and Novafabricia), 3-7 (Brifacia metastellaris Fitzhugh, 1998, Fabricia stellaris, Parafabricia ventricingulata Fitzhugh, 1992, and some species of Augeneriella and Fabricinuda), or 3-8 (most Fabricinuda species) [4]. Pseudospatulate chaetae are absent in Bansella, Echinofabricia, Fabriciola, Pseudofabriciola and Rubifabriciola [4]. Species of Rubifabriciola have pin-head chaetae on the abdominal neuropodia [27] (Figure 8m). These chaetae have a blunt tip and a number of small teeth apically. Transitional chaetae (Figure 8k) replacing thoracic uncini occur on the last thoracic chaetigers (chaetigers 6-8) of Brandtika spp., Manayunkia godlewskii (Nusbaum, 1901), females of M. occidentalis Atkinson, Bartholomew and Rouse, 2020 and M. zenkewitschii Sitnikova, Shcherbakov and Kharchenko, 1997 [4,215-217].

The thoracic uncini are characterized by a long manubrium (homologous to handle in sabellids) and a main fang surmounted by a series of smaller teeth (Figure 8d). A slightly offset medium-sized tooth occurs between the large main fang and the smaller apical teeth in Augeneriella, Fabricia, Fabricinuda, Monroika, Novafabricia, Parafabricia, Pseudofabricia, Pseudoaugeneriella and some species of Pseudofabriciola [42]. The apical teeth can also be approximately of the same size in Echinofabricia, or may gradually decrease in size away from the main fang as in Fabriciola, Manayunkia and some species of Pseudofabriciola [57]. The abdominal uncini usually exhibit multiple rows of equal-sized teeth (Figure 8h). Only members of Novafabricia chilensis (Hartmann-Schröder, 1962) and N. gerdi (HartmannSchröder, 1974) have uncini with a single row of teeth.

Fabriciids usually have three abdominal chaetigers (Figure 8j). However, Brandtika spp., Fabriciola minuta Rouse, 1996, and Monroika africana have two abdominal chaetigers, while Echinofabricia spp. has four [215,218,219].

The pygidium is triangular or bluntly rounded in most species, but has a ventral depression in Pseudofabriciola analis Fitzhugh, Giangrande and Simboura, 1994. A pair of black or dark brown pygidial eyes is present in most species of Fabriciidae (Figure 8j). They are red in Echinofabricia (disappearing after fixation) and Rubifabriciola (persisting after fixation), but are always absent in all species of Manayunkia and Monroika, Fabriciola parvus Rouse, 1993 and two undescribed deep-sea species [220]. Unique among members of Sabellida, emergent spicules are present in the epithelium of Echinofabricia species [27].

\subsubsection{Shortcuts to Identification of Sabellidae}

Sabellids are relatively easily to visually identify to the generic level because genera are provided with unique and conspicuous diagnostic features (Figure 9). The diversity of radiolar eyes within members of Sabellidae is remarkable (e.g., Figure 9a), and the eye number, type and arrangement offer a very powerful taxonomic aid for genera and species identification $[24,69,221]$. The large compound eyes located in the tips of dorsal radioles are unequivocally characteristic of members of Acromegalomma, whereas the large single and bulging compound eyes arranged, in a longitudinal row on the outer margin of the radioles, are typical of members of Pseudopotamilla Bush, 1904 (Figure 9a). Anamobaea Krøyer, 1856 and Notaulax Tauber, 1879 are easily recognized due to the presence of long radiolar lobes with dorsal and ventral flanges. Other generic synapomorphies related to the radiolar morphology are the dichotomously branching radioles, found only in Schizobranchia Bush, 1905 and Eudistylia Bush, 1905 (most likely due to a regeneration processes [111,222]), and the external paired radiolar appendages, called stylodes, in members of Branchiomma (Figure 9e). Euchone is recognisable by the presence of a typical pre-pygidial depression with lateral wings, but this character is only visible in adults. Species of Claviramus Fitzhugh, 2002 have radiolar tips with expanded flanges, rolled inwards or bilobed, this feature is easily seen if radioles are 
complete. Potamethus Chamberlin, 1919 is recognizable due the very long collar (2-4 times the length of next thoracic segment). Other genera are recognised by unique traits, which are not evident to a naked eye and require optic aids. These are the typical companion chaetae of members of Parasabella, the absence of posterior peristomial ring collar in members of Amphiglena, or the presence of a broad, oblique glandular (clitellum-like) ring on third abdominal segment in Euchonoides. Internal structures, such as the rows of vacuolated cells supporting radioles, dorsal lips and radiolar appendages, are of taxonomic significance and often used for species discrimination [64,102,122,223-226].

\subsubsection{Serpulidae Diagnostic Characters}

Within Serpulidae, body symmetry separates serpulins from spirorbins, as serpulins are bilaterally symmetrical, while spirorbins are curved in the direction of the tube coil. Specific identification has been based on a combination of characters such as morphology of the operculum and opercular peduncle, degree of development of the collar and thoracic membranes, and chaetal structures (Figure 10). Tube morphology and ultrastructure are important for identification of both extant and fossil taxa [227] (Figure 10a-c). Serpulid genera have been described on the basis of unique characters or on unique combinations of characters (or absence of characters), rather than on presence of shared derived characters. Mentioned here morphological characters used for serpulid identification have been described in details and illustrated in ten Hove and Kupriyanova [110], Wong et al. [228], Kupriyanova et al. [214].

The operculum that is present in most serpulins and in all spirorbins is one of the most important diagnostic characters (Figure 10d-h). The shape of the operculum varies significantly, ranging from soft transparent vesicles to complex structures reinforced with chitinous or calcareous endplates and spines. The distinct funnel-shaped opercula of Crucigera and Serpula are composed of numerous radii (Figure 10d), while in Hydroides the funnel is topped with a verticil of chitinous spines (Figure 10e). The operculum-bearing radiole can be identical to others (e.g., Filograna, Apomatus Philippi, 1844), but usually is modified into a smooth peduncle (Figure 10j). In cross-section, the peduncle is commonly cylindrical, but it is flat ribbon-like in members of the genus Metavermilia Bush, 1905. Below the operculum, the peduncle may bear diagnostic distal wings (e.g., Spirobranchus) (Figure 10h).

The collar segment bears only notopodial (collar) chaetae that may be absent (e.g., Ditrupa Berkeley, 1835, Marifugia, Placostegus Philippi, 1844). The collar chaetae may bear four types of diagnostic modified chaetae: bayonet-type (e.g., Serpula, Hydroides, Figure 10i), fin-and-blade (e.g., Chitinopoma, Protis Ehlers, 1887), Spirobranchus-type (e.g., Spirobranchus, Laminatubus ten Hove and Zibrowius, 1986) and Ficopomatus-type (see [214]). Tonguelets, located between collar lobes, are diagnostic of the genera Spirobranchus and Pyrgopolon de Montfort, 1808. The thoracic membranes (Figure 101) may be ending at the first (Ditrupa) or the second thoracic chaetiger (Chitinopoma), or may continue to the mid-thorax (e.g., Pomatostegus, Vermiliopsis Saint-Joseph, 1894), to the last thoracic chaetiger (some Spiraserpula Regenhardt, 1961 and Metavermilia spp.), or past the end of the thorax forming the ventral apron (e.g., Ficopomatus, Serpula, Hydroides, Protula, Spirobranchus) (Figure $10 \mathrm{~m}$ ). In most genera the thorax consists of seven chaetigerous segments (first with collar chaetae only and six with both notopodia and neuropodia). The number of thoracic segments varies from five (Tanturia Ben-Eliahu, 1976 and Bathyditrupa Kupriyanova, 1993) or six (Laminatubus, Hyalopomatus Marenzeller, 1878, Spirodiscus Fauvel, 1909) to 10 (Kimberleya Pillai, 2009), while spirorbins have three to five thoracic segments. 


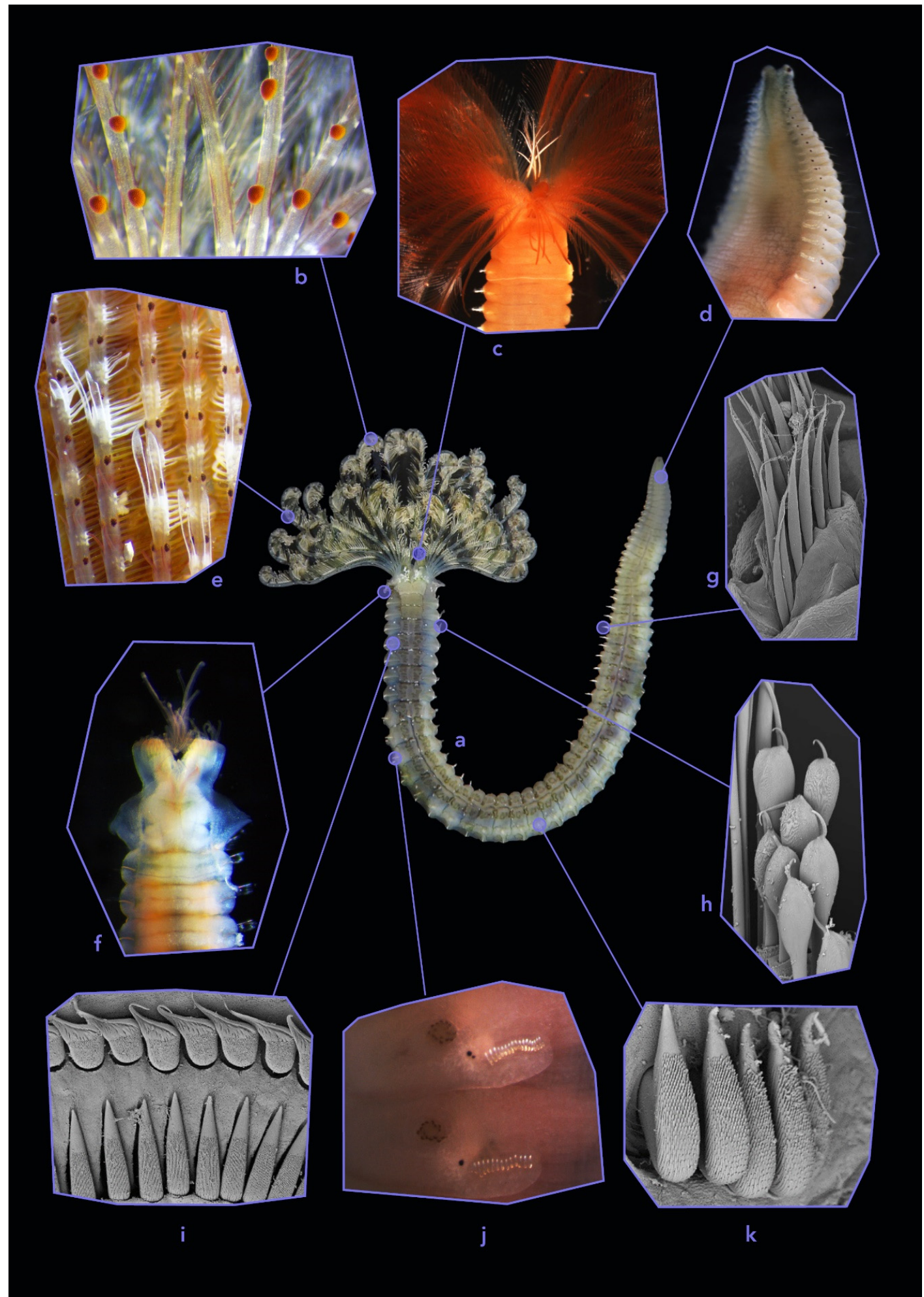

Figure 9. Main diagnostic characters for members of Sabellidae. (a) Parasabella microphtalma, ventral view; (b) Compound eyes on dorsal radioles, Pseudopotamilla sp.; (c) Radiolar internal structures, Chone infundibiliformis; (d) Pygidial morphology, Bispira sp.; (e) Radiolar stylodes, Branchiomma sp.; (f) Collar, radiolar lobes and glandular girdle in second chaetiger, Jasmineira sp.; (g) Abdominal chaetae, Parasabella sp.; (h) Thoracic chaetae, Parasabella sp.; (i) Thoracic uncini and companion chaetae, Notaulax sp.; (j) Parapodia morphology and arrangement of chaetae, Bispira sp.; (k) Abdominal uncini, Notaulax sp. 


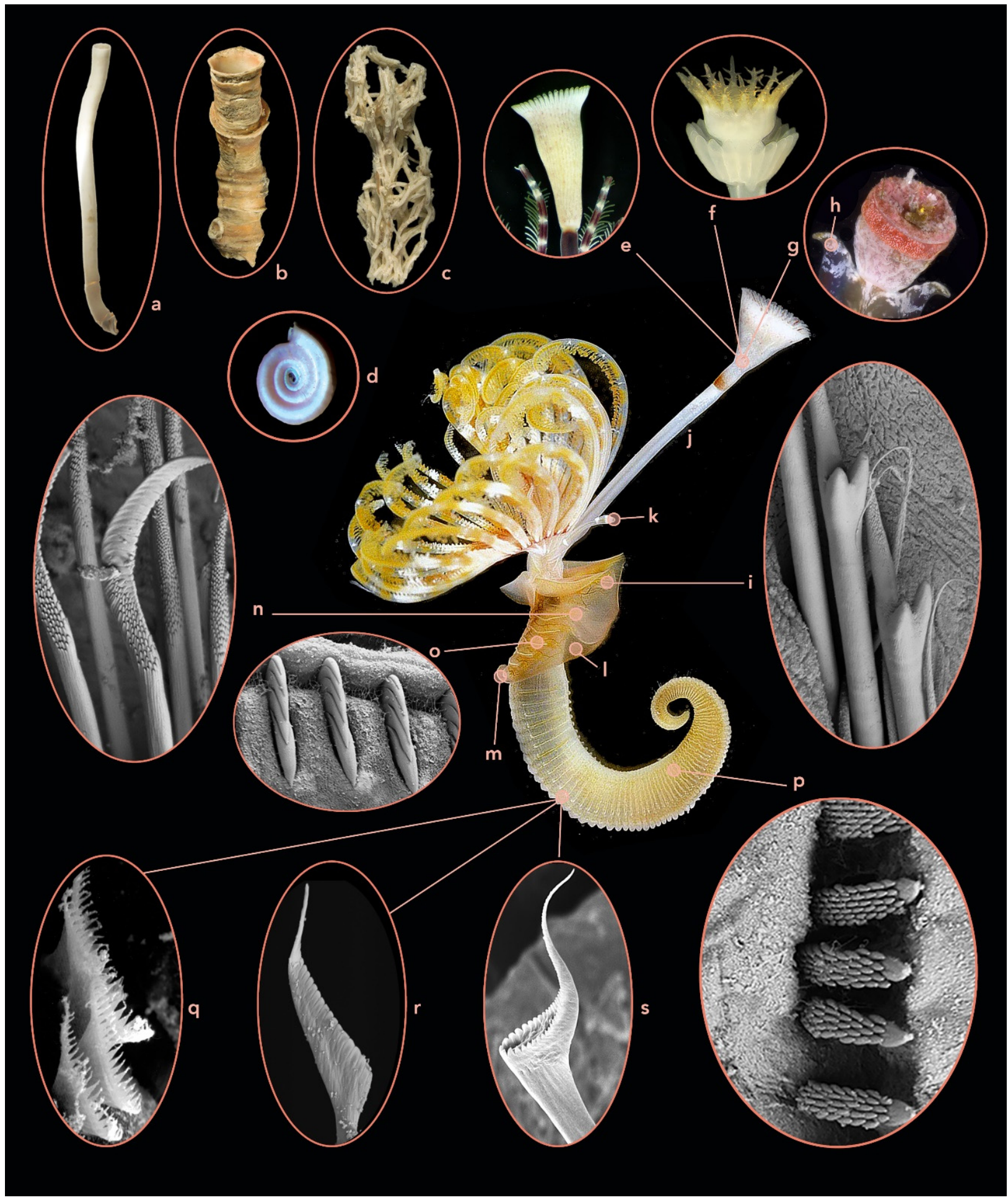

Figure 10. Main diagnostic characters for members of Serpulidae. Centre: lateral view of a Serpula specimen removed from the tube; (a-d) Tubes: Hyalopomatus biformis (a), Serpula vermicularis (b), Filograna implexa (c), Circeis armoricana (d); (e-h) Opercula: Serpula (e), Hydroides (f), Spirobranchus (g) showing distal wings (h); (i) Special (bayonet) collar chaetae of Hydroides; (j) Peduncle; (k) Pseudoperculum; (1) Thoracic membranes; (m) Apron; (n) Thoracic Apomatus (sickle-shaped) chaetae of Vermiliopsis; (o) Thoracic saw-shaped uncini of Hydroides; (p) Posterior abdominal rasp-shaped uncini of Hydroides; (q-s) Abdominal chaetae: flat trumpet-shaped of Serpula; (q), flat geniculate of Vermiliopsis; (r) true trumpet-shaped of Spirobranchus (s). (a-c,f) by E. Wong, (d) by A. Rzhavsky, (e) by G. Rouse, (g,h) by A. Semenov, (j-m) (central photo of Serpula) by F. Verbiest, (n-s) (SEM images) by S. Lindsay). 
In the posterior thoracic segments chaetae are supplemented by diagnostically important Apomatus or sickle-shaped chaetae (Figure 10n). The number of vertical teeth rows in the thoracic and anterior abdominal uncini (saw-shaped, with one row of teeth, e.g., Hydroides, Serpula (Figure 10o); rasp-shaped, with several rows of teeth, e.g., Hyalopomatus, Placostegus, Marifugia; or saw-to rasp-shaped, from with one tooth distally to a row of up to five teeth near the peg, e.g., Filogranula Langerhans, 1884) is diagnostic. Posterior abdominal uncini are always rasp-shaped (Figure 10p). Even more important is the shape of the anterior tooth of uncini. The anterior teeth are either pointed fangs (e.g., Filograna, Hydroides, and Serpula (Figure 10o,p), and pileolariin spirorbins), or a wide variety of blunt 'wedge' shaped pegs (e.g., Pseudovermilia Bush, 1907, Spirobranchus, Galeolaria, Ficopomatus, Hyalopomatus, Chitinopoma, Pyrgolopon, Vermiliopsis, Protula).

The shape of abdominal chaetae is very important for generic diagnostics (Figure 10q-s). The simplest forms are capillary (Bathyditrupa) and acicular (Paumotella Chamberlin, 1919). The flat trumpet-shaped chaetae with a single row of teeth are found in Crucigera, Hydroides, Serpula (Figure 10q). Abdominal chaetae previously referred to as 'geniculate' are two distinct types of chaetae, true trumpet-shaped, typical for, e.g., Ficopomatus, Galeolaria, Placostegus, Spirobranchus (Figure 10s) that lack thoracic 'Apomatus' chaetae, and flat geniculate are found in taxa with Apomatus chaetae, e.g., spirorbins, Apomatus, Chitinopoma, Vermiliopsis (Figure 10r).

3.3.4. Data and Techniques Used for Species Identification and Systematics Initial Collection, Observation and Fixation in the Field

To identify individuals to the species level, specimens are first examined under a stereomicroscope. If conditions in the field permit, they should be examined and photographed alive to document colouration. Removing individuals from their tubes, specially serpulids, without any tube or specimen damage is rarely possible unless $0.05 \%$ phenol-seawater solution is used for several hours [229-231]. This method does not work in spirorbins (Bick pers. obs.) and it is unknown whether DNA is affected by phenol. It is important to examine and photograph intact tubes if they are broken to extract animals.

Fixation and preservation of specimens vary depending on further purposes of samples. Specimens aimed for a morphological study only are commonly fixed in a $4 \%$ solution of formaldehyde in sea water for 24-48 h, if possible after relaxation of individuals (in magnesium chloride). Animals are then rinsed in distilled water and preserved in 70-80\% ethanol. For scanning electron microscopy (SEM) osmium tetraoxide is preferable as a fixative.

Specimens aimed for genetic sequencing should avoid all contact with formaldehyde as it degrades DNA, impeding amplification of the usual size fragments to be sequenced. Best procedures for DNA sequencing include fixation of fresh specimens in high concentration ethanol (the higher the better) and storing samples at $4-6^{\circ} \mathrm{C}$, or at least not in direct sunlight at room temperature. The ethanol should be changed at least once, preferably more often. RNA sequencing may need other protocols such as fixing with RNAlater. For integrative (morphological and molecular) studies, a tissue sample taken from a specimen should be fixed in ethanol and stored in a fridge or a freezer, while the rest of the specimen should be fixed in formalin and preserved in ethanol. Further reading on fixation and preservation of samples is found at Rouse and Pleijel [232].

\section{Morphological Studies of Preserved Specimens}

When examining freshly preserved or museum material lacking natural pigmentation, staining with methyl (or methylene) green (blue) helps to increase contrast and to reveal glandular patterns, including thoracic ventral shields and glandular girdles [24]. Examination of chaetae requires higher magnification $(>100 x)$, therefore, chaetae and notoand neuropodia are dissected from the specimen, placed on a slide in a drop of ethanol, glycerin or permanent media, and covered with a cover glass. Applying gentle pressure on the cover glass ensures that uncini and chaetae lay in a lateral position. Using SEM is essential to reveal details of external features, such as ciliation, chaetal morphology and 
body wall microstructure, as well as anatomical features not easily distinguished in small specimens (appendages of the radiolar crown, for example). SEM is also an indispensable tool to examine tube ultrastructure, important for taxonomy of serpulids (reviewed by Ippolitov et al. [227]).

Structures of the radiolar crown, e.g., the rows of vacuolated cells supporting the radioles, dorsal and ventral lips, dorsal radiolar and pinnular as well as ventral radiolar appendages, and a parallel lamella in Sabellidae, dorsal lips and ventral filamentous appendages in Fabriciidae, are examined after fine sections with a sharp blade or, better, histological semi-thin sections are made and mounted on temporary or permanent slides, and stained with solutions, such as Mallory or Cason (e.g., [226]).

Morphometric characters such as counts (e.g., numbers of radioles or pinnules), measurements and proportions of soft body parts (e.g., thorax to abdomen ratio, length of dorsal lips) have traditionally been considered diagnostic for some taxa, but individuals may show sexual dimorphism [216], size and age-related variability $([70,233]$ or their size may be affected by anaesthetization and fixation techniques [234], which needs to be considered when comparing material.

For drawings to be made to scale, a camera Lucida attached to both the stereo- and the compound scopes is used. Traditional ink drawing (pencil sketching followed by India ink tracing) is currently supplemented or replaced by digital tracing of scanned pencil sketches, using a drawing pad (e.g., [235]). Advances in digital photography and universal availability of microscope-mounted digital cameras and Z-stacking software also resulted in photographs of live or preserved specimens, rather than line drawings being used in species descriptions. Use of SEM micrographs helps to illustrate both chaetal and soft body diagnostic features characters with precision and objectivity. Micro-computed tomography techniques have been proved useful in studies of internal anatomy in sabellids and serpulids $([49,236,237]$, and may offer taxonomically useful information.

\section{Genetic Data}

Genetic methods have been used in studies of Sabellida for nearly 20 years. The earliest publication by Patty et al. [238] used the C1 regions of $28 \mathrm{~S}$ (123 bp) of 16 species to assess evolutionary relationships among Sabellidae. Kupriyanova et al. [45] published the first phylogeny of Serpulidae based on analyses of $18 \mathrm{~S}$ rDNA, $28 \mathrm{~S}$ rDNA, and morphological characters of 29 taxa. Combination of molecular (18S rDNA, the D1 region of $28 \mathrm{~S}$ rDNA, and histone H3) and morphological datasets have been used to assess for the first time the relationships within Fabriciidae [27]. Other studies of Sabellida have used a limited number of molecular markers commonly used in polychaete systematics [239]. Currently, the number of sequences in GenBank is 246 for Fabriciidae, 814 for Sabellidae, and 2880 for Serpulidae, figures that indicate the relative larger effort put into molecular studies in serpulids compared to the other two families (Figure 11). In addition, "BOLD Systems [36] includes 443 barcodes (fragments of COI gene) of Serpulidae, 349 of these records are mined from GenBank and 19 diferent BOLD records are also shared with GenBank. Similarly, BOLD holds 692 COI sabellid barcodes, 399 of which are mined from GenBank and 148 BOLD records that were also uploaded in GenBank. Among the unidentified 105 sabellids there is an unknown number of sequences that belong to fabriciids as this database still follows the old clasitication. Sumarising, there are 75 serpulid and 145 sabellid/fabriciid COI sequences available in BOLD, in addition to those found in GenBank. 


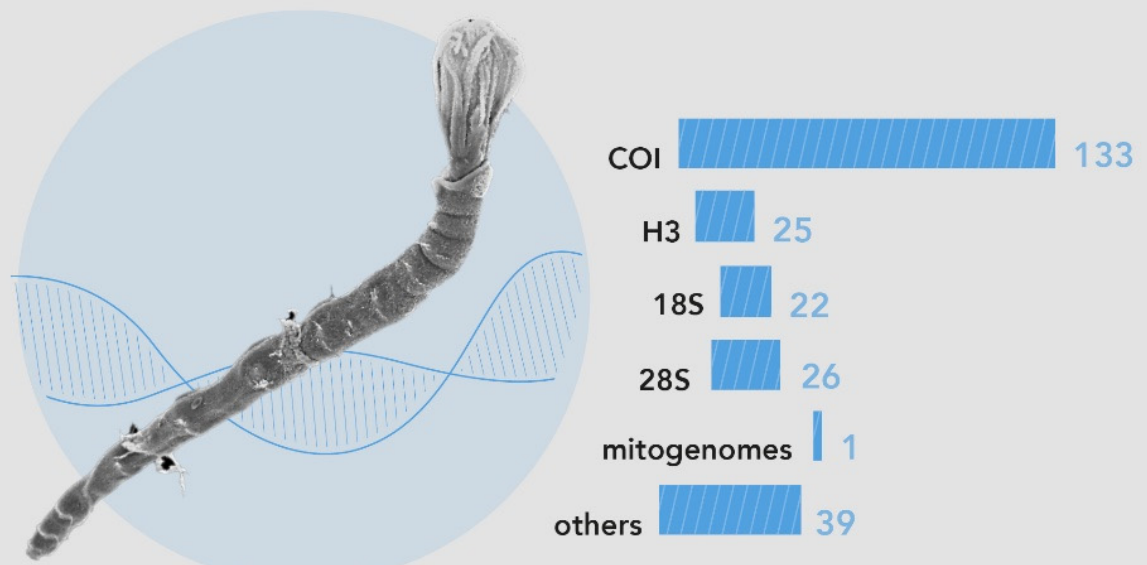

387
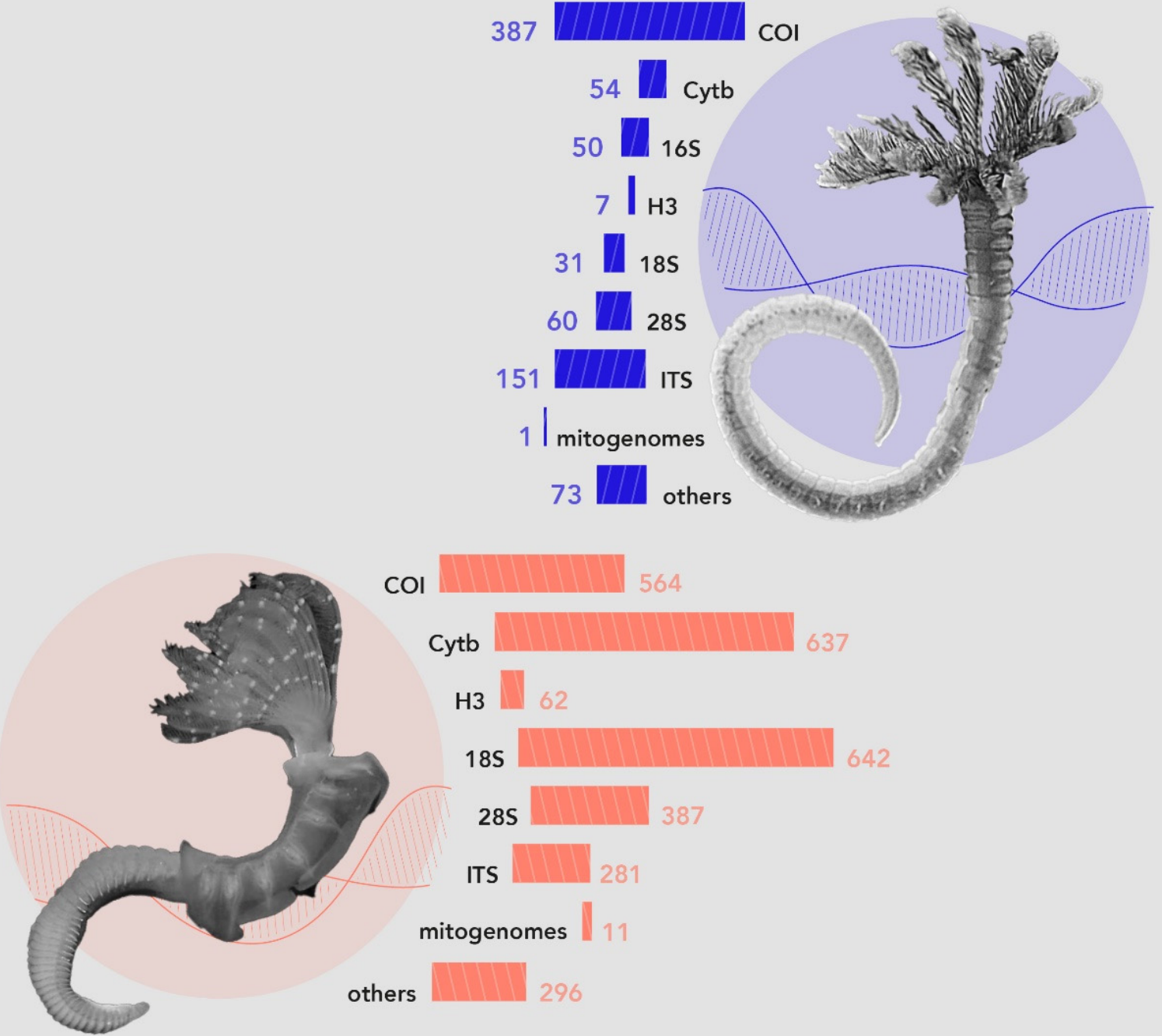

Fabriciidae Sabellidae Serpulidae

Figure 11. Number of sequences available in Genbank for Fabriciidae, Sabellidae; and Serpulidae.

The universal DNA barcoding fragment of COI gene is by far the most popular marker for the Fabriciidae, accounting for $54 \%$ (133 sequences) of the sequences available for this group (Figure 11), and Sabellidae, 38\% (387 sequences) (Figure 11). For Serpulidae, despite all efforts (reviewed in Sun et al. [78]), no COI sequences had been available until 
Carr et al. [240] reported six. However, Sun et al. [76], who developed genus-specific primers to generate COI sequences for 11 species of Hydroides, showed that "serpulid" sequences in Carr et al. [240] are likely from bacteria. Progress in COI barcoding in serpulids is mainly a result of new primer development [77]. Currently, the number of COI sequences for members of Serpulidae in Genbank is 564 (not including those mentioned problematic sequences [240], Figure 11).

Other markers widely used in systematics studies of Sabellida are nuclear 18S (642 sequences for Serpulidae, 31 for Sabellidae, 22 for Fabriciidae), 28S RNA (387 for Serpulidae, 60 for Sabellidae, 26 for Fabriciidae), mitochondrial cytochrome b (cytb) (637 for Serpulidae and 54 for Sabellidae), nuclear internal transcribed spacer (ITS2), ATP synthase, and Histone H3 (Figure 11). Mitochondrial 16S, widely used in sabellids (50 sequences in Genbank), has not been successfully amplified for serpulids.

Manayunkia is the fabriciid genus with most sequences in GenBank (179). The Sabellidae genera with most available sequences are Branchiomma (259), followed by Sabella (86) and Sabellastarte (61). Among the serpulids, Hydroides is the genus with the highest number of sequences in GenBank (1366), followed by Spirobranchus (601); all the rest have at least one order of magnitude less sequences available (Figure 12).

Although Sabellida are still behind other annelids in terms of genomic approach, several studies recently reported mitochondrial genomes and used transcriptomes for resolving systematics and evolutionary questions within this group. The first Sabellida mitochondrial genome was published for the serpulid Spirobranchus giganteus (Pallas, 1776) [241]. Mitochondrial genome sequences of ten Hydroides species have been reported in Sun et al. [242]. The mitochondrial genomes of Sabella spallanzanii (Gmelin, 1791) and freshwater fabriciid Manayunkia occidentalis were recently published [243,244]. The phylogeny by Tilic et al. [3] includes transcriptome sequences of 20 species of Sabellida (three fabriciids, 15 sabellids, and two serpulids), containing up to 3015 orthologous genes. Several other studies have also dealt with expressed sequence tag (EST) libraries and transcriptomes to address molecular mechanisms of larval settlement, or gene order and loss [245] in serpulids, adding up to 4205 sequences of mRNAs of larval cDNA library. With current fast adoption of the genomic approach, the number of sequences is expected to raise dramatically in the near future.

Species Delimitation and Identification

Application of molecular methods in combination with traditional morphological techniques or alone have expanded in the last two decades with regard to species delimitation in annelids in general, and in Sabellida, in particular. These methods are sustained by the definition of species as independently evolving entities (metapopulations), that are genetically (and often phenotypically) distinct [246,247]. Thus, species are expected to be reciprocally monophyletic clusters, morphologically distinct and/or genetically divergent, as a result of evolutionary forces applied to closely related lineages. Molecular-based approaches have not only improved species delimitation by providing additional evidence to morphological taxonomy, but also helped to reveal cryptic (only genetically distinct) species [248].

In Fabriciidae, even though species appear morphologically similar due to the animal's small size and the diagnostic features being difficult to recognize by non-specialists, molecular approach to species identification and delimitation is still uncommon. Only one species, Manayunkia occidentalis, has been described based mainly on genetic data [216].

In Sabellidae, boundaries between species within the genera Amphiglena, Branchiomma, Parasabella, Pseudobranchiomma Jones, 1962, Sabellastarte and Sabellomma Nogueira, Fitzhugh and Rossi, 2010 were assessed with molecular and morphological data [70,72-74]. Results revealed cryptic diversity hidden in species complexes and helped to assess the diagnostic features traditionally used for morphological species identification $[2,27,72-74,103,140]$. 


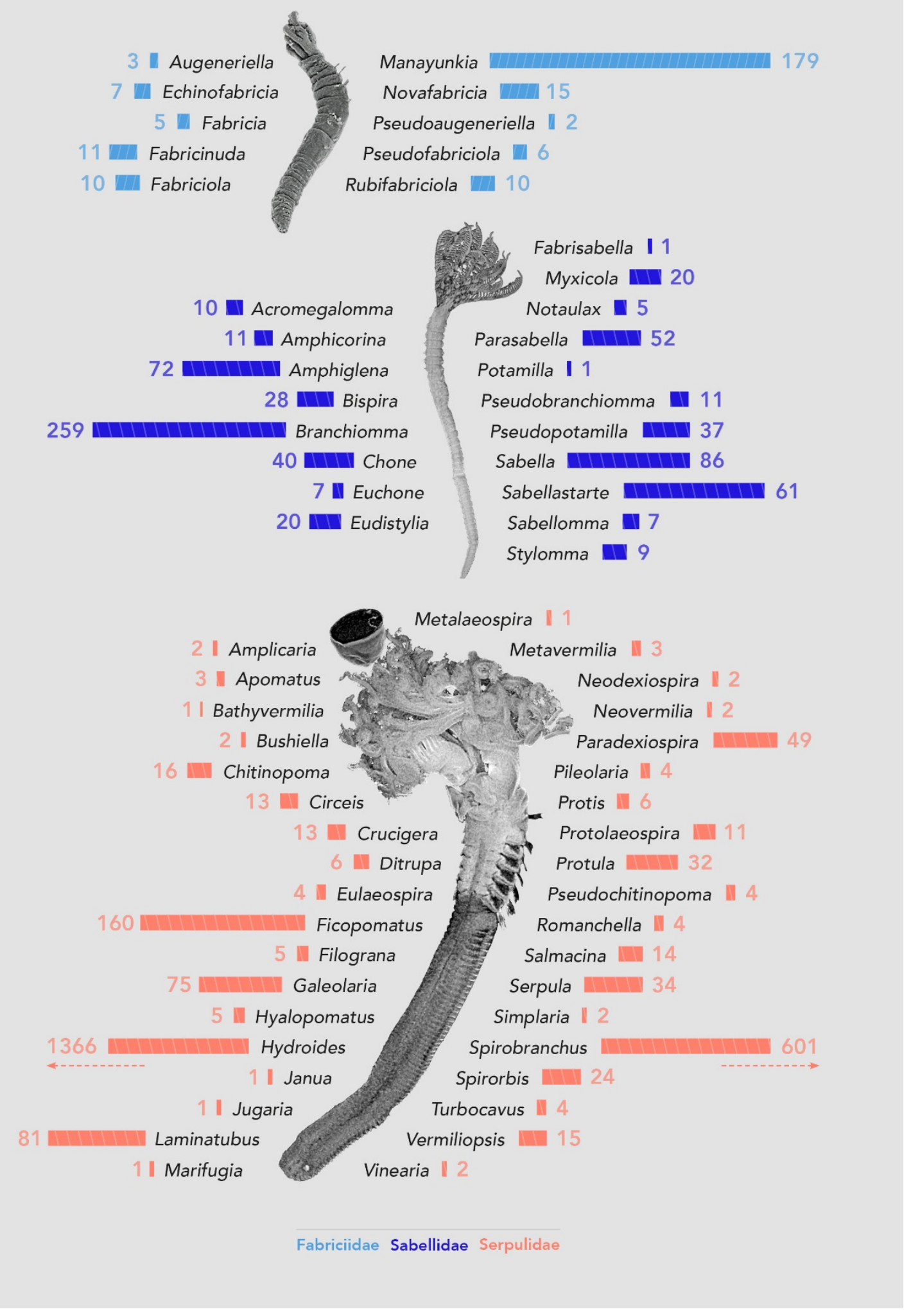

Figure 12. Number of DNA sequences available in GenBank for genera in Fabriciidae, Sabellidae, and Serpulidae.

In Serpulidae, the study of Halt et al. [249] was the first to name a new species in Sabellida without morphological indicators, after analyses of DNA revealed two cryptic species with non-overlapping distributions within Galeolaria caespitosa Lamarck, 1818. Another 
study revealed three genetic species with overlapping distributions within Ficopomatus enigmaticus (Fauvel, 1923), two cryptic and one morphologically distinct [204]. A combination of molecular and morphological data helped to partially resolve species complexes within the genera Hydroides [203,250,251] and Spirobranchus [84,193,252].

The idea of 'DNA barcoding' is that a species can be uniquely characterised by a short DNA fragment and then identified by comparing such a fragment from an unknown specimen to a reference DNA sequence [253]. Initially, a 650 base pair fragment of the mitochondrial COI was proposed as a standard barcoding gene for animals [253] because of its variability among closely related taxa and supposed ease of amplification. Later, however, a number of other mitochondrial markers (cytb, e.g., [81-84,193,204,249,252] and nuclear (ITS, [82,249]) have been used, especially in serpulids where amplification of COI proved to be challenging. The first attempts to use DNA data alone while ignoring any morphological and biogeographic evidence to identify potentially invasive serpulids [254], were rather a failure. The authors mistakenly claimed discovery of an Australian species Spirobranchus taeniatus (Lamarck, 1818) (mostly likely Spirobranchus triqueter) and North American Serpula columbiana Johnson, 1901 (almost certainly Serpula vermicularis) attached to drifting marine litter in the Mediterranean, after comparing (minimum 97\% nucleotide identity was accepted) partial sequences of the conservative (thus unsuitable for specieslevel barcoding) $18 \mathrm{~S}$ gene with the limited set of sequences available in GenBank. Similarly, Langeneck et al. [255] criticised another paper by the same authors (Rech et al. [256]) who identified specimens associated with floating debris in the Lagoon of Venice as Hydroides sanctaecrucis, suggesting its presence in the Mediterranean might have been overlooked due to misidentification as common $H$. dianthus. Rech et al. [256] again did not examine the morphology of the specimens and used $18 \mathrm{~S}$ sequences for identification, accepting an identity $\geq 97 \%$ with sequences of $H$. sanctaecrucis in GenBank. However, $18 \mathrm{~S}$ rDNA sequences are ill-suited for molecular identification because they have identity close to $100 \%$ in closely related species. The low sequence identity shows that the specimens in Rech et al. [256] study did not belong to H. sanctaecrucis, and the species name should be removed from checklists of species non-indigenous for the Mediterranean [255].

\subsection{Ecology, Distribution and Biogeography \\ 3.4.1. Ecology \\ Fabriciidae}

A review of the ecology and biology of Fabriciidae was published recently [4]. Most fabriciids occur in intertidal and subtidal zones, mainly in sheltered areas on sandy, muddy or rocky sediments, in mangroves, on red and green algal mats, and in seagrass beds, with low benthic species richness.

Fabriciids are mainly distributed in marine and brackish ecosystems worldwide, but species of the genus Manayunkia are also common in freshwater, and even hypersaline lakes, where they survive salinities of 82 psu for several months [257]. The abundance of some species tends to be very high in habitats with low biodiversity. The highest abundances of Fabricia stellaris and Manayunkia aestuarina (over $10^{6}$ ind. $\mathrm{m}^{-2}$ ) have been reported in physiologically stressful conditions, such as sediments with a high organic matter content and waters of highly variable salinities [258-261]. A reduction in organic matter content from $1.8 \%$ to $1.0 \%$ in the Baltic Sea was followed by a reduction in fabriciid abundance from 16000 to 6000 ind. $\mathrm{m}^{-2}$ [262]. Giangrande et al. [263] found five fabriciid species in a coastal Mediterranean system naturally acidified by carbon dioxide vent emissions. Among these, Parafabricia mazzellae Giangrande, Gambi, Micheli and Kroeker, 2014 and Brifacia aragonensis Giangrande, Gambi, Micheli and Kroeker, 2014 were most abundant even in the extremely low $\mathrm{pH}$ zone (pH 6.6-7.2).

Fabriciidae species produce flexible tubes consisting of the finest sediment particles stabilized by mucus. Detritus might also be deposited on the outside of the tubes. Fabriciids are not obligatory tube dwellers and they can voluntarily leave their tubes and build new 
ones. When outside, they crawl with the posterior end in front, while the radiolar crown is folded up and dragged behind [264,265].

Fabriciids are suspension-feeders like other Sabellida, but Manayunkia spp. are deposit feeders. In addition to detritus, they ingest bacteria, heterotrophic protozoa, cyanophyceans and diatoms. The sizes of the ingested particles range from 1-2 $\mu \mathrm{m}$ to $2-7 \mu \mathrm{m}$ and occasionally reach up to $20 \mu \mathrm{m}$ [265].

Some fabriciids are commensals of molluscs, e.g., the freshwater Brandtika asiatica Jones, 1974 and Monroika africana $[215,266]$, or the marine Rubifabriciola tonerella (Banse, 1959) and Novafabricia infratorquata (Fitzhugh, 1983) [231], but these species have been also found in other substrates. Another example of commensalism is the occurrence of peritrichous ciliates on anterior chaetigers in Manayunkia aestuarina [4]. Manayunkia speciosa Leidy, 1859 is an obligate invertebrate host of the myxozoan parasites Ceratonova shasta (Noble, 1950) and Parvicapsula minibicornis Kent, Whitaker and Dawe, 1997, which cause ceratomyxosis in salmon and trout in North America [267,268].

\section{Sabellidae}

A review of ecology and biology of sabellids was recently published [24]. Sabellids are able to inhabit either hard or soft sediments. Species of Amphiglena, Bispira, Perkinsiana, Pseudobranchiomma, Sabellomma, Sabellastarte and Stylomma Knight-Jones, 1997 mainly inhabit littoral hard substrates, as epibionts of algae, or associated with biogenic structures, including live coral or rubble $[2,68,73,74,269,270]$. Some species of Perkinsiana and Pseudopotamilla associated with dead coral and limestone sediments are capable of actively boring into the calcium carbonate [271,272].

Several species of Acromegalomma, Amphiglena, Branchiomma, Eudistylia, Notaulax, Parasabella, Pseudobranchiomma and Sabella are abundant in biofouling communities [72, $74,101,147,273-276]$. Some of the soft bottom species need large and stable enough surface (shell, rock, holdfast or root) to attach to build their tubes. This is characteristic of species of Branchiomma, Parasabella, Bispira manicata (Grube, 1878), Acromegalomma, or the Mediterranean Sabella spallanzanii, a species associated, in natural conditions, to Posidonia K. Koenig seagrass roots $[73,129,133,277,278]$. However, other soft-bottom species can build tubes within the sediment grains, like Euchonoides meone Magalhães, Bailey-Brock and Tovar-Hernández, 2020. This species is found near a sewage outfall in Hawaii, reaching 141,046 ind $/ \mathrm{m}^{2}$, the highest densities ever reported for Sabellidae [279].

Sabellids have been only recently found in chemosynthesis-based environments, such as hydrothermal vents, methane seeps and organic falls, and their diversity in such habitats is poorly understood. Bispira wireni (Johansson, 1922) was reported from a hydrothermal vent from Okinawa, Japan [280]. Jasmineira sp. and an undetermined sabellid colonized bone and sunken wood in the southwestern Indian Ridge [281]. Unidentified sabellids have been reported from methane seeps in the Gulf of Mexico [282] and Chile [283]. Recently, an undescribed species of Bispira was found at a deep-sea cold seep off the Pacific coast of Costa Rica [284].

Although the group is typically marine, a few exceptional species have adapted to brackish and even fresh water environments. The most remarkable example is the exclusively freshwater genus Caobangia. Euryhaline sabellids are, for example, the Australian Desdemona aniara Hutchings and Murray, 1984 and Laonome triangularis Hutchings and Murray, 1984, Indian Potamilla leptochaeta Southern, 1921, American Aracia sinaloae TovarHernández, 2014, and the cryptogenic Desdemona ornata Banse, 1957, Euchone limnicola Reish, 1959, and Laonome xeprovala Bick and Bastrop, 2018 [68,102,285-290]. Some species typically found in fully marine conditions are tolerant to brackish water conditions, e.g., members of Euchone, Branchiomma and Parasabella [147,291], while Laonome calida Capa, 2007 and L. albicingillum Hsieh, 1995 have been reported in environments ranging from fully marine to freshwater [68,292-294].

With the exception of Glomerula piloseta, that inhabits calcareous tubes, all sabellids build tubes by secreting the mucous base and enforcing it with different size particles they 
attach, including mud, sand, feces or biogenic fragments [24]. Smaller species are more liable to leave the tubes if disturbed and can build new ones [295], but larger species, even if capable to build new tubes, tend to inhabit the same one for longer periods or their whole lives [270,296,297].

Until very recently, sabellids have been found mostly in areas of high productivity and assumed to be obligatory suspension feeders [298]. However, a sabellid-bacterial symbiosis, fueled by methane, between a still undescribed species of Bispira and methane-oxidizing Methylococcales bacteria, has recently been reported from a methane seep [284]. This makes Bispira a new addition to the list of annelids (including Siboglinidae and two new serpulids of the genus Laminatubus, see below) relaying on chemosynthetic symbionts for nutrition.

Associations of sabellids with other organisms relate to their ability to bore into calcium carbonate. The seven species of Caobangia are commensals or parasites of freshwater gastropods and bivalves in rivers of southeastern Asia [289,299]. Terebrasabella heterouncinata Fitzhugh and Rouse, 1999 bores into the shells of marine gastropods, including abalones and limpets, in South Africa and California [66,300,301]. Notaulax montiporicola Tovar-Hernández and ten Hove, 2020 associated with the living coral Montipora nodosa (Dana, 1846) does not bore into coral, but uses crevices to settle and allows coral tissue to grow around its tube [101].

Serpulidae

A review of ecology and biology of serpulids was recently published [214]. Serpulids are typical on hard substrates in all marine environments. Inhabitants of areas with predominantly soft-sediments always attach to rocky outcrops, stones and shells, and can deal with high sedimentation rate by building their tubes upwards to avoid being buried in the sediment [302]. Many serpulids are notorious opportunistic foulers, capable of colonising any available hard substrates. The ability to settle and build large aggregations on human-made surfaces makes serpulids important and troublesome members of fouling communities. However, some show high habitat selectivity, resulting from non-random larval settlement and juvenile survival (reviewed by Kupriyanova et al. [303]). A few unusual serpulids are pre-adapted to living unattached on soft substrates in subtidalshelf (Ditrupa) [110] or bathyal-abyssal (Bathyditrupa and Spirodiscus) environments [107]. However, larvae of free-living Ditrupa need to attach initially to small particles during settlement and metamorphosis to start building the tube [304].

Serpulids are some of recognizable animals to inhabit the periphery of seeps and hydrothermal vents. Laminatubus alvini ten Hove and Zibrowius, 1986 and Protis hydrothermica ten Hove and Zibrowius, 1986 were the first serpulids to be formally described from vent communities of East Pacific Rise and Laminatubus is known from other seeps (e.g., Pescadero Transform Fault, Gulf of California) and vents, e.g., Alarcon Rise, Gulf of California [305]. Hyalopomatus mironovi Kupriyanova, 1993 and Protis sp. were reported from hydrothermal vents of North Fiji [306]. Less is known about seep-associated serpulids, as more species have been reported from fossil than modern hydrocarbon seeps [307]. Serpulids (tentatively identified as members of Neovermilia Day, 1961) have been reported from cold seep communities in Nankai Trough [308], the Peruvian active margin [309], the Terevaka ridge [310], the Peru Trench, Middle American Trench off Mexico [311], and the Barbados prism [312].

Although serpulids are predominately marine, some species of Hydroides tolerate mixohaline conditions (e.g., [313], for H. elegans (Haswell, 1883)), while representatives of Ficopomatus can cope with a wide range of salinities and are common in brackish-water environments world-wide [110]. Marifugia cavatica Absolon and Hrabĕ, 1930, closely related to Ficopomatus, is the only known truly fresh-water serpulid, inhabitant of subterranean caves of the Dinaric Alps [46].

Serpulids produce their calcareous tubes using a pair of calcium carbonate secreting glands located on the collar. As obligate tube dwellers, they never leave their tubes and 
cannot build new ones if removed. Adult serpulids lie in the tube with their dorsum facing the substrate and locomotion is limited to partial emergence from and withdrawal into the tube [314]. Hiding behaviour is a common antipredator tactic, and animals may adjust the durations of such behaviour to current benefits and costs [315].

As suspension-feeders, serpulids show varying abilities in particle sorting and clearance rates. High planktonic biomass removal ( $>50 \%$ of initial standing stock) and significant differences in clearance for different components of the community by reef-building Ficopomatus enigmaticus indicate that the serpulid can regulate planktonic biomass and promote changes in plankton community structure [316]. Ditrupa arietina (Müller, 1776) lives unattached in soft sediments and ingests diatoms, haptophytes, bacteria and cyanobacteria ranging from 1 to $50 \mu \mathrm{m}$ in size, and the origin of the food is both planktonic and benthic [317]. Recently metanotrophy (similar to that found for members of Bispira sp.) has been reported, as a result of symbiosis between two species of the genus Laminatubus (L. joicebrooskae Rouse and Kupriyanova, 2021 and L. paulbrooksi Rouse and Kupriyanova, 2021) and methane-oxidizing Methylococcales bacteria, from a seep off Costa Rica [284].

While a large number of serpulids is found in coral reefs on coral rubble (e.g., [318]: Fiji, [319]: Okinawa, Japan, [179]: Queensland, Australia), only some taxa, such as Floriprotis Uchida, 1978, Pseudovermilia, Spirobranchus and Vermiliopsis spp., are found in association with live corals. Some Spirobranchus species are reported as obligate associates of corals to the extent that their successful settlement occurs only on live corals (e.g., [320-322]), although recent observations indicate that while Spirobranchus larvae have a preference for live corals, they will survive on other substrates [83]. Many serpulids form epizootic associations with other invertebrates, mostly molluscs, crustaceans, bryozoans, and sponges. For example, Hydroides spongicola Benedict, 1887 occurs symbiotically in the chemically aggressive do-not-touch-me sponge Neofibularia nolitangere (Duchassin and Michelotti, 1864), while Circeis paguri Knight-Jones and Knight-Jones, 1977 is associated with hermit crabs (reviewed in [303]). Spirorbins are commonly found in specific epiphytic associations with macrophytes and their settlement can be stimulated by algal extracts $[323,324]$.

\subsubsection{Biogeography, Distribution and Bathymetry}

Members of the Sabellida are found world-wide and, like most polychaetes, for much of the 20th century were assumed to have naturally wide, even cosmopolitan, distributions (e.g., [166,194,325]). Darling and Carlton [326] use the term eucosmopolitan to refer to the species with naturally broad distribution (found in two or more oceans). However, recent studies overwhelmingly show that 'cosmopolitan' taxa represent complexes of either morphospecies or cryptic species (reviewed in [327]). All evidence to date suggests that polychaetes have restricted natural geographic and bathymetric distributions, thus taxa reported with wide ranges should be treated as potential species complexes. Two general exceptions to the rule of restricted distributions are deep-sea and invasive species. Ranges of deep-sea polychaetes are expected to be wider than those found in shallow seas as a result of stable environmental conditions over wide distances, a traditional view (e.g., [328]) also supported by recent studies (e.g., [329,330]). Annelids that are easily translocated by anthropogenic means can establish and become invasive in remote localities, consequently expanding their ranges [327]).

Biodiversity patterns may be influenced not only by intrinsic ecological and historical factors, but also by 'extrinsic factors' sensu Giangrande and Licciano [331]. When a group is studied by a few specialists working in a particular area, species distribution may correlate with that of the specialists ('author effect'). The concentration of taxonomic expertise in some regions may increase the number of species in those areas compared to less studied areas ('concentration effect').

\section{Fabriciidae}

Fabriciids have been described from all marine realms except for the Tropical Eastern Pacific (Table S1). Temperate Northern Atlantic is the province with the highest number 
of fabriciids (16 species), followed by Tropical Atlantic (13 species), Temperate Northern Pacific and Western Indo-Pacific (11 species each), Central Indo-Pacific (10 species) and Temperate Australasia (six species), Temperate Southern Africa (four species), Eastern IndoPacific (two species), and Actic, Southern Ocean, and Temperate Southern America, each with a single species (Table S1). Most of the 4739 georeferenced occurrences in GBIF are also from the Temperate North Atlantic Realm and the Tropical Atlantic (Figure 13) and refer to members of Fabricia, Fabricinuda and Manayunkia [34]. There are records from neither Tropical Eastern Pacific nor from Western Indo-Pacific, the west coast of South America, and the west coast of Africa. The historical records until 1999, compiled by Giangrande and Licciano [331], showed $55.8 \%$ of the total fabriciid species are found in the tropics. Interestingly, the currently available information, based on species type localities show sthat most species were described from the Atlantic Ocean, at all latitudes. Explanation to latest results could be 'concentration effect', with taxonomic expertise accumulated at both sides of the Atlantic, and poor state of knowledge elsewhere.

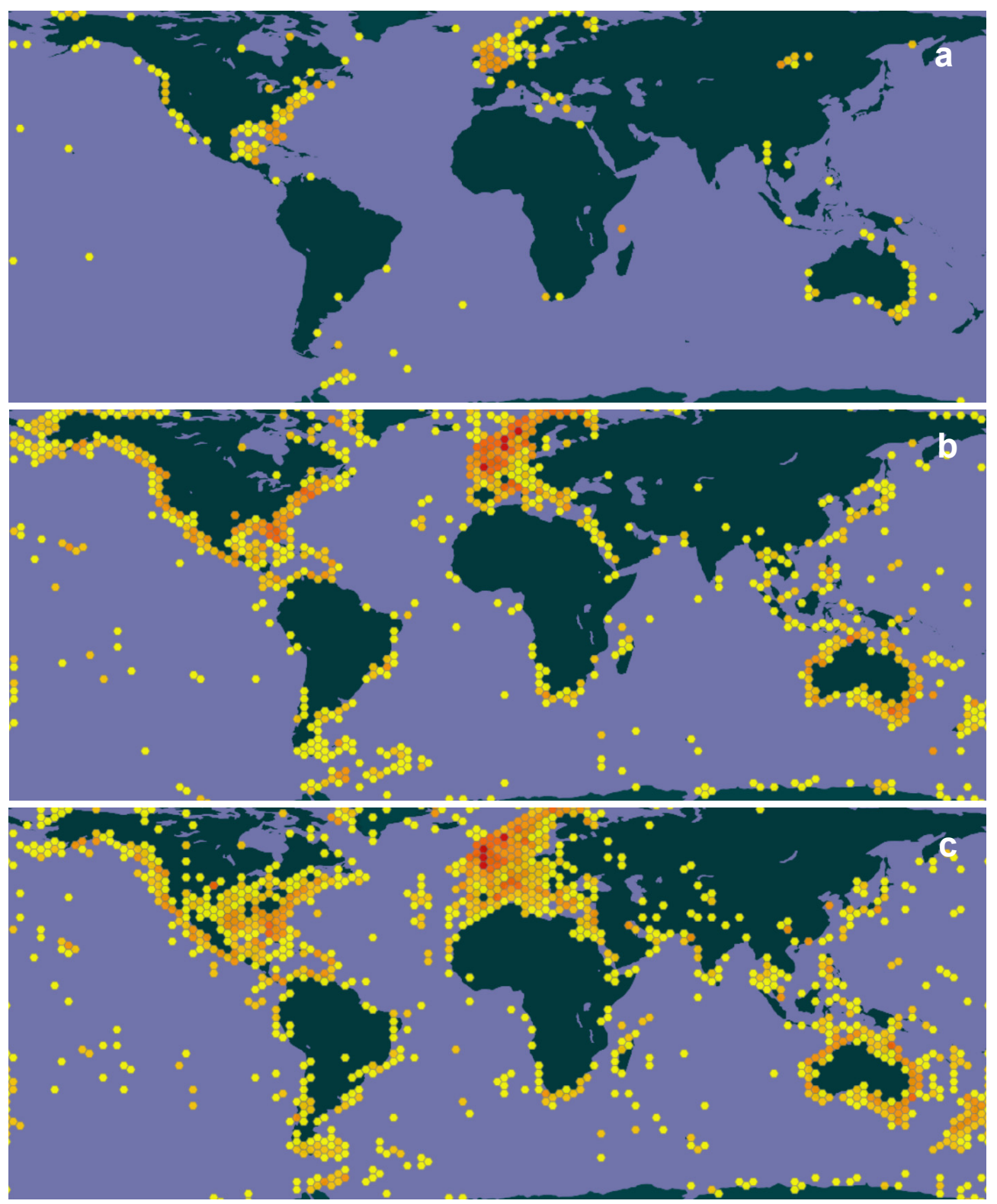

Figure 13. Georeferenced occurrences from GBIF. (a) Fabriciidae; (b) Sabellidae; (c) Serpulidae. 
The species of most genera are distributed almost worldwide. The adaptability of Fabriciidae to different environments and the wide distribution of some taxa can be shown by the example of the genus Manayunkia. The ten extant Manayunkia species occur worldwide in marine, brackish and freshwater habitats, as well as hypersaline lakes. Their common ancestor was most likely already present in marine habitats [4]. There are ten species adapted to freshwater conditions: M. speciosa and M. occidentalis (Nearctic); $M$. zenkewitschii, M. baicalensis (Nusbaum, 1901) and M. godlewskii (Palearctic) [216,217]. One species, M. athalassia Hutchings, Dekker and Geddes, 1981, was found in hypersaline lakes in Australia [257], another species, M. mizu Rouse, 1996, in marine habitats [219,332] and three species, M. aestuarina, M. caspica Annenkova, 1928), M. brasiliensis Banse, 1956, in brackish environments $[333,334]$ (Nogueira pers. obs.).

Most Fabriciidae occur in intertidal and subtidal waters. Only certain Pseudofabriciola species (e.g., P. californica Fitzhugh, 1991, P. filamentosa (Day, 1963), P. filaris Fitzhugh, 2002, and P. longipyga Fitzhugh, Giangrande and Simboura, 1994), Fabricinuda longilabrum Fitzhugh, 2002 and Raficiba barryi occur between depths of $50 \mathrm{~m}$ and $335 \mathrm{~m}[53,58,63,335]$. The record of Fabricia sabella (Ehrenberg, 1937) reported by Hartman (1965) from $1000 \mathrm{~m}$ off New England needs a revision because the nominal F. stellaris is a brackish-water species from the Baltic Sea. In the southwest Atlantic, exceptionally, two yet undescribed species provisionally assigned to the genera Fabriciola and Novafabricia have been found at $4500 \mathrm{~m}$ [220] and one other of Fabriciola from the Okhotsk Sea below $2000 \mathrm{~m}$ (Table 5).

Table 5. Deepest records for members of Sabellida below $1000 \mathrm{~m}$.

\begin{tabular}{|c|c|c|}
\hline Taxon & Depth (m) & References \\
\hline $\begin{array}{c}\text { FABRICIIDAE } \\
\text { Fabriciola sp. (Okhotsk Sea) } \\
\text { Fabriciola sp. } \\
\text { Novafabricia sp. }\end{array}$ & $\begin{array}{c}>2000 \\
4600 \\
4600\end{array}$ & $\begin{array}{c}\text { Alalykina } 2020 \\
\text { Baumhaker } 2012 \\
\text { Baumhaker } 2012\end{array}$ \\
\hline SABELLIDAE & & \\
\hline Jasmineira bermudensis Hartman, 1965 & 1000 & Original description \\
\hline Potaspina australiensis Capa, 2007 & 1000 & Original description \\
\hline Euchone magna (Fauchald, 1972) & 1071 & Original description \\
\hline Perkinsiana assimilis (McIntosh, 1885) & 1100 & Original description \\
\hline Chone gracilis Moore, 1906 & 1244 & Méndez 2006 \\
\hline Bispira wireni (Johansson, 1922) & 1335 & Capa et al. 2013 \\
\hline Potamethus filiformis Hartmann-Schröder, 1977 & 1430 & Original description \\
\hline Pseudopotamilla intermedia Moore, 1905 & 1682 & Original description \\
\hline Bispira sp. (Costa Rica) & 1887 & Goffredi et al. 2020 \\
\hline Chone sp. (Okhotsk Sea and N. Pacific abyss) & $>2000$ & Alalykina 2020 \\
\hline Euchone sp. (Okhotsk Sea and N. Pacific abyss) & $>2000$ & Alalykina 2020 \\
\hline Jasmineira sp. (Okhotsk Sea and N. Pacific abyss) & $>2000$ & Alalykina 2020 \\
\hline Potamethus sp. 1 (Okhotsk Sea and N. Pacific abyss) & $>2000$ & Alalykina 2020 \\
\hline Potamethus sp. 2 (Okhotsk Sea) & $>2000$ & Alalykina 2020 \\
\hline Potamethus singularis Hartman, 1965 & 2000 & Original description \\
\hline Potamilla neglecta (Sars, 1851) & 2030 & Hansen 1882 \\
\hline Potamethus malmgreni (Hansen, 1878) & 2222 & Original description \\
\hline Euchone cf. incolor Hartman, 1965 & 2500 & Alalykina 2020 \\
\hline Fabrisabella similis Fauchald, 1972 & 2520 & Original description \\
\hline Potamethus scotiae (Pixell, 1913) & 2578 & Original description \\
\hline Euchone papillosa (Sars, 1851) & 2900 & Uschakov 1955; Levenstein 1969 \\
\hline Jasmineria pacifica Annenkova, 1937 & 2900 & Original description \\
\hline Jasmineira schaudinni Augener, 1912 & 3500 & $\begin{array}{l}\text { Augener } 1912 \text { (abyssal, no depth given); Jirkov } \\
\text { 1982, } 2001\end{array}$ \\
\hline Chone infundibuliformis Krøyer, 1856 & 3521 & Wesenberg-Lund 1950 \\
\hline cf Sabellidae species 1 (Clarion-Clipperton Zone) & 4029 & Amon et al. 2017 \\
\hline Potamethus mucronatus (Moore, 1923) & 4131 & Original description, as Notaulax \\
\hline
\end{tabular}


Table 5. Cont

\begin{tabular}{|c|c|c|}
\hline Taxon & Depth (m) & References \\
\hline Potamilla abyssicola Uschakov, 1952 & 4200 & $\begin{array}{c}\text { Original description; Levenstein } 1961 \text { 1969; } \\
\text { Alalykina } 2020\end{array}$ \\
\hline Potamethus spathiferus (Ehlers, 1887) & 4360 & Fauvel 1914 \\
\hline Euchone incolor Hartman, 1965 & 4862 & Original description; Hartman 1971 \\
\hline ?Potamethus sp. Mozambique Basin & 5068 & Hartman 1971 \\
\hline Potamehus dubius (Eliason, 1951) & 5860 & Original description \\
\hline Jasmineira sp. Japan & 6207 & Levenstein 1961b \\
\hline Potamethus singularis Hartman, 1965 & 6023 & Original description; Hartman 1971 \\
\hline Sabellidae sp. Pacific Ocean & 8042 & Levenstein 1969; Lemche et al. 1976 \\
\hline Potamilla sp. Kurile-Kamchatka Trench & 8100 & Uschakov 1952; Belyaev 1989 \\
\hline Jasmineira sp. Kermadec Trench Trench & 8300 & $\begin{array}{c}\text { Kirkegaard 1956; Hartman and Fauchald 1971; } \\
\text { Belayev } 1972\end{array}$ \\
\hline Potamethus sp. Izu-Bonin Trench & 8735 & Belayev 1989 \\
\hline Jasmineira filitovae Levenstein, 1961 (as Potamethus) & 9735 & Levenstein 1969, 1973; Belyaev 1989 \\
\hline \multicolumn{3}{|l|}{ SERPULIDAE } \\
\hline Laminatubus joicebrooksae Rouse and Kupriyanova 2021 & 1011 & Original description \\
\hline Hyalopomatus madreporae Sanfilippo, 2009 & 1146 & Original description \\
\hline Neovermilia falcigera (Roule, 1898) & 1580 & Zibrowius and ten Hove 1987 \\
\hline $\begin{array}{c}\text { Metavermilia ogasawaraensis Nishi, Kupriyanova and } \\
\text { Tachikawa, } 2007\end{array}$ & 1603 & Original description \\
\hline Zibrovermilia zibrowii Kupriyanova and Ippolitov, 2015 & 1710 & Original description \\
\hline Hyalopomatus dieteri Kupriyanova and Ippolitov, 2015 & 1980 & Original description \\
\hline Hyalopomatus biformis (Hartman, 1960) & 1982 & Kupriyanova and Nishi 2010 \\
\hline Metavermilia zibrowii Bailey-Brock and Magalhães, 2012 & 2013 & Original description \\
\hline Vermiliopsis notialis Monro, 1930 & 2016 & Averintsev 1974 \\
\hline Bushiella (Jugaria) atlantica (Knight-Jones, 1978) & 2100 & Original description \\
\hline Bathyvermilia islandica Sanfilippo, 2001 & 2399 & Original description \\
\hline Filogranula stellata (Southward, 1963) & 2464 & Ben-Eliahu and Fiege 1996 \\
\hline Hyalopomatus variorugosus Ben-Eliahu and Fiege, 1996 & 2474 & Original description \\
\hline Laminatubus paulbrooksi Rouse and Kupriyanova, 2021 & 2478 & Original description \\
\hline Protis browni (Pixell, 1913) & 2585 & Original description \\
\hline Protis hydrothermica ten Hove and Zibrowius 1986 & 2620 & ten Hove and Zibrowius 1986 \\
\hline Hyalopomatus marenzelleri Langerhans, 1884 & 2800 & Zibrowius 1968, 1969, 1977 \\
\hline Laminatubus alvini ten Hove and Zibrowius, 1986 & 2842 & Original description \\
\hline Neovermilia cf. sphaeropomata (Benham, 1927) & 3261 & Rouse and Kupriyanova 2021 \\
\hline Apomatus globifer Théel, 1878 & 3384 & Uschakov 1957 \\
\hline Hyalopomatus claparedii Marenzeller, 1878 & 3550 & Kupriyanova and Jirkov 1997 \\
\hline Hyalopomatus jirkovi Kupriyanova, 1993 & 3949 & Kupriyanova et al. 2011 \\
\hline Spirodiscus grimaldii Fauvel, 1909 & 4124 & ten Hove and Kupriyanova 2009 \\
\hline Bathyvermilia kupriyanovae Bastida-Zavala, 2008 & 4190 & Original description \\
\hline Apomatus similis Marion and Bobretzky, 1875 & 4400 & Fauvel (1909), Fauvel (1914) \\
\hline Spirodiscus groenlandicus (McIntosh, 1877) & 4440 & Kupriyanova and Ippolitov 2015 \\
\hline Bathyvermilia zibrowiusi Kupriyanova, 1993 & 4550 & Kupriyanova et al. 2011 \\
\hline Hyalopomatus sikorskii Kupriyanova, 1993 & 4550 & Kupriyanova et al. 2011 \\
\hline Protis simplex Ehlers, 1887 & 4810 & Knight-Jones et al. (1997) \\
\hline Protis polyoperculata Kupriyanova, 1993 & 5110 & Original description \\
\hline Hyalopomatus mironovi Kupriyanova, 1993 & 5216 & Rouse and Kupriyanova 2021 \\
\hline Protis arctica (Hansen, 1879) & 5300 & Zibrowius 1969 \\
\hline Bathyvermilia challengeri Zibrowius, 1973 & 5719 & Original description \\
\hline Bathyvermilia langerhansi Fauvel, 1909 & 5987 & Eliason 1951 \\
\hline Bathyvermilia gregrousei Kupriyanova and Ippolitov, 2015 & 6050 & Original description \\
\hline Nidificaria levensteinae (Bailey-Brock and Knight-Jones, & 6096 & Original description \\
\hline Bathyditrupa hovei Kupriyanova, 1993 & 6330 & Kupriyanova et al. 2011 \\
\hline Protis sp. 2 & 8345 & Kupriyanova et al. 2014 \\
\hline Protis sp. 1 & 9735 & Kupriyanova et al. 2014 \\
\hline
\end{tabular}




\section{Sabellidae}

Sabellids have been described from all marine realms and all seven members of Caobangia are known so far are from the Indo-Malay limnic realm. In the current analysis, the Temperate Northern Atlantic is the realm with the highest number of sabellids described (125 species), which represents $24 \%$ of the sabellids described worldwide, followed by the Temperate Northern Pacific (79 species, 15\%), Central Indo-Pacific (58 species, 11\%), Tropical Atlantic (56 species, 11\%), Temperate Australasia (37), Western Indo-Pacific (20 species), Temperate South America (28 species), Southern Ocean (24 species), Temperate Southern Africa (18), Arctic (16 species), Tropical Eastern Pacific (15 species), Eastern IndoPacific (8), 23 species non-marine and eight species with unknown type locality (Table S2). Most of the 117073 georeferenced occurrences in GBIF are from the Temperate Northern Atlantic and the Tropical Atlantic realms, and records belong to members of genera Euchone, Jasmineira, Chone and Sabella [34] (Figure 13). Other realms with large representation of sabellids records are Tropical Atlantic, the Arctic and Temperate Australasia. The number of described species and number of records is higher in the Atlantic than in any other ocean, the result that contradicts the patterns showing an increase in sabellid species richness towards the tropics, and mainly in the Indo-Pacific [331].

Some genera with few species, such as Anamobaea or Stylomma, and the freshwater Caobangia, are exclusive of tropical environments [69,158,229], and others, such as Branchiomma, Bispira, Acromegalomma, Notaulax, Sabellastarte, and Sabellonga, have either tropical or temperate distribution [149,157,336-338]. A few genera show a significant preference for colder waters and are either well represented at greater depths or in higher latitudes (e.g., members of Chone, Euchone, and Jasmineira). The Antarctic region is richer in number of genera and species than the Arctic [24] (Figure 7), and genera, such as Perkinsiana, are mainly distributed in the Southern Ocean [212].

Sabellids found below $6000 \mathrm{~m}$ have all been reported from the Western Pacific Ocean (Table 5) and include species of the genera Jasmineira, Potamethus and Potamilla Malmgren, 1866 [339-344]. Species reported in the abyssal zone (2000-6000 m deep) include members of the genera Chone, Euchone, Fabrisabella, Jasmineira, Potamilla, and Potamethus (Table 5). The genus Potamethus is the most speciose deep-sea taxon (Table 5). Jasmineira filitovae Levenstein, 1961 is the deepest record $(9735 \mathrm{~m})$. Sabellids reported from between 1000 and $2000 \mathrm{~m}$ depths include species of Bispira, Chone, Euchone, Jasmineira, Perkinsiana, Potamethus, Potaspina and Pseudopotamilla [280,284,345-348]. Among all sabellids recorded below $1000 \mathrm{~m}, 13$ have been identified to the genus level only, most probably constituting new species.

Serpulidae

Serpulids have been described from all marine realms. The realm with highest number of species is the Temperate Northern Atlantic (108 species), followed by the Temperate Northern Pacific (92), Central Indo-Pacific (74), Tropical Atlantic (71), Western Indo-Pacific (52), Temperate Australasia (41), Tropical Eastern Pacific (28), Southern Ocean (23), Temperate South America (21), Arctic (16), Temperate Southern Africa (15), Eastern Indo-Pacific (8), and nine species with unknown type locality (Table S3). Of the 107859 georeferenced records in GBIF (2020), more than half are within the Temperate Northern Atlantic (mainly identified as Spirobranchus, Hydroides, Ditrupa and Spirorbis) and following realms with highest occurrences are the Temperate Australasia (mainly Spirobranchus, Hydroides, Galeolaria and Serpula) and the Tropical Atlantic (Hydroides, Spirobranchus, Vermiliopsis and Pseudovermilia) (Figure 13). There were no previous analyses of global serpulid distribution patterns to compare with these data.

Serpulids are common inhabitants of intertidal, subtidal and shelf locations, but they can occur at all latitudes from intertidal to hadal depths. Spirorbin bathymetric distribution ranges from littoral to abyssal depths, but they are most commonly found in the sublittoral zone. The best known representatives of the genera Ficopomatus, Galeolaria, Hydroides, Salmacina Claparède, 1870, Serpula, Spirobranchus and Vermiliopsis are inhabitants of shal- 
lower waters (below $500 \mathrm{~m}$ ), and so are representatives of less known and more cryptic genera, such as, for example, Chitinopoma, Floriprotis, Josephella Caullery and Mesnil, 1896, Metavermilia, Pomatostegus, Pseudochitinopoma Zibrowius, 1969, Pseudovermilia, Rhodopsis Bush, 1905, Semivermilia ten Hove, 1975 and Spiraserpula. Some genera, e.g., Apomatus, Filogranula, Neovermilia and Protula may include both subtidal and bathyal species.

Serpulids found below $2000 \mathrm{~m}$ were reviewed by Zibrowius [349], who corrected Hartman's [339] compendium of abyssal polychaetes by removing taxa typical of subtidal and shelf depths (Hydroides, Ditrupa, Placostegus, Serpula, Spirobranchus). As a result, he listed 25 species, including one unidentifiable specimen from Kermadec Trench (6620-6730 m, [350]). Belyaev [344] added two unidentified hadal specimens from 6410-6757 m (Aleutian Trench) to $9715-9735 \mathrm{~m}$ (Izu-Bonin Trench), the latter being the deepest record for a serpulid. In their review, Paterson et al. [351] list only 26 serpulids from over $2000 \mathrm{~m}$ world-wide, including five species from depths beyond $3500 \mathrm{~m}$, all described by Kupriyanova [352,353] from Kuril-Kamchatka Trench alone. Sanfilippo [354], Kupriyanova et al. [355,356] Kupriyanova and Nishi [357], Bailey-Brock and Magalhães [184], Kupriyanova and Ippolitov [107], and Rouse and Kupriyanova [358] recently provided additional records and descriptions of new deep-sea serpulid taxa. Kupriyanova et al. [356] reviewed and revised hadal records below $5000 \mathrm{~m}$, demonstrating that the deepest serpulid records ( 8345 and $9735 \mathrm{~m}$ ) reported in Belyaev's book [344]) belong to the genus Protis.

Currently, 36 named species have published records below $1000 \mathrm{~m}, 28$ of them are reported from below $2000 \mathrm{~m}$ (Table 5), although Kupriyanova et al. [356] lists eight records in open nomenclature (Bathyvermilia sp., Hyalopomatus sp., Protis sp., Serpulidae gen. sp. A and B). In summary, serpulids from bathyal and abyssal depths $(>1000 \mathrm{~m})$ are found in the genera Apomatus, Bathyditrupa, Bathyvermilia Zibrowius, 1973, Bushiella (Jugaria) KnightJones, 1978, Filogranula, Hyalopomatus, Laminatubus, Metavermilia, Neovermilia, Nidificaria Knight-Jones, 1984, Spirodiscus, Protis, and Zibrovermilia Kupriyanova and Ippolitov, 2015, but only species of Bathyditrupa, Bathyvermilia, Hyalopomatus, and Protis are found in the abyss, also penetrating into the hadal zone. Non-operculate Protula and operculate Apomatus are often confused with non-operculate and operculate Protis sp., so that abyssal records of supposed Protula and Apomatus might belong to Protis [356].

\subsection{Non-Indigenous and Invasive Species}

Shallow-water Sabellida, due to their sedentary tubicolous lifestyle, are common members of biofouling communities and are easily translocated by anthropogenic means, i. e., on ship hulls and floating marine debris [147]. Distribution as larvae in ballast water has been suggested [359-362] and is the most plausible hypothesis for Sabella spallanzanii [363,364], but larvae of sabellids and serpulids have never been reported from ballast water samples. If become established in remote localities, such translocated taxa significantly expand their ranges. However, some reported broad distributions are a reflection of uncertain taxonomic status. Such species remain as widely distributed or even 'cosmopolitan' only as long taxonomic uncertainty persists, and a molecular investigation usually split hem into a number of geographically restricted species.

According to the literature survey of polychaetes reported outside their natural ranges, Serpulidae and Sabellidae account for $22 \%$ of the total number of non-native polychaetes world-wide [365]. However, a critical assessment of non-indigenous species records is needed. The number of such species is a function of the research effort put into distinguishing non-native and native taxa, which in turn depends on the knowledge of native diversity and the state of taxonomy of a group. Integrative taxonomic revisions of species with reportedly global distributions are important because such taxa may include cryptic invaders that are particularly difficult to track because they are often assumed to be native species or wrongly assigned to other invasive species [366].

Several criteria for distinguishing non-indigenous from native species have been proposed as lines of indirect evidence, such as a new record for an area, a new localised occurrence showing a population explosion, species with disjoint distribution, with insufficient 
natural dispersal capabilities to account for observed distribution range, or species associated with means of human-made transport, e.g., found on ship hulls (e.g., $[172,367,368]$ ). In the last two decades, molecular genetics tools have proved indispensable direct lines of evidence for assessing the status of a reportedly invasive taxon. The population genetics studies allow testing if distant populations belong to same species, and also if genetic variability of suspected new arrivals is lower than that observed in the native range, which indicates a recent translocation (e.g., [72,74,204,294,368-370]). Molecular data can also help to determine the origin of non-native populations. For example, haplotype variability analysis suggests that although serpulid Hydroides dianthus (Verrill, 1873) was originally described from New England, its native range may be the Mediterranean [250].

A good example of a sabellid with an uncertain invasive status is Laonome calida described from the Calliope River, Australia, and later reported as introduced in the Netherlands [294], Odra River and the Sea of Azov [371,372]. Simultaneously, the morphologically similar Laonome xeprovala was described from the Baltic Sea, and DNA sequences from specimens from the Netherlands and Sea of Azov showed that they belong to the same species [102]. Neither L. calida nor L. xeprovala had been reported from Europe before 2014, and increased occurrences suggest a recent invasion [373]. Molecular analyses, however, are needed to determine whether the European populations belong to the same species found in Australia (implying that L. xeprovala could be a junior synonym of L. calida) or a distinct non-indigenous species of unknown origin is found in Europe (in which case $L$. xeprovala would be valid). Similarly, Branchiomma species are easily translocated outside of their native ranges [72,129,147,374-379], but members of this genus are so morphologically homogenous that species identification using morphological characters only is problematic. Therefore, assessing the identity of Branchiomma spp. with invasive potential requires a comprehensive generic revision, including DNA-based species delimitation analyses [72,379]. Other records still to be confirmed by molecular studies are the sabellids Euchone variabilis Hutchings and Murray, 1984, Laonome triangularis, Desdemona aniara and the three species of Pseudobranchiomma reported from Australia [74,126,380,381]. 


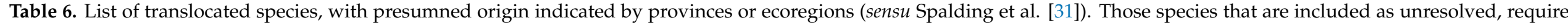
confirmation and two are not cosmopolitan (Branchiomma curtum and Parasabella pallida). NA: not applicable.

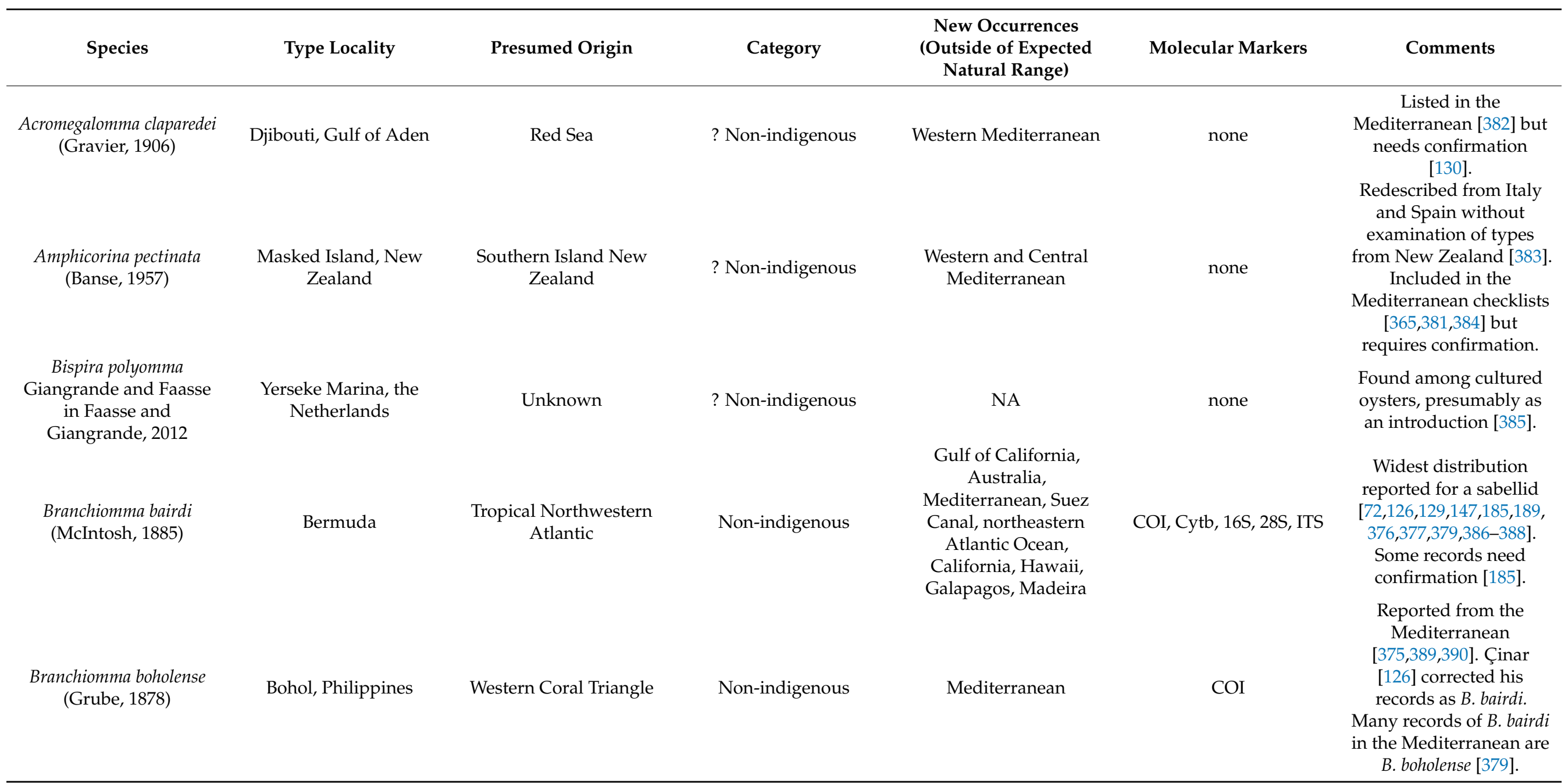


Table 6. Cont

\begin{tabular}{|c|c|c|c|c|c|c|}
\hline Species & Type Locality & Presumed Origin & Category & $\begin{array}{c}\text { New Occurrences } \\
\text { (Outside of Expected } \\
\text { Natural Range) }\end{array}$ & Molecular Markers & Comments \\
\hline $\begin{array}{l}\text { Branchiomma coheni } \\
\text { Tovar-Hernández and } \\
\text { Knight-Jones, } 2006\end{array}$ & Panama, Pacific & Tropical Eastern Pacific & Non-indigenous & $\begin{array}{l}\text { Florida, Gulf of } \\
\text { California }\end{array}$ & none & $\begin{array}{c}\text { Records from Tampa Bay } \\
\text { and Gulf of California } \\
\text { [391] first since } \\
\text { description. In Florida it } \\
\text { was an early detected } \\
\text { non-indigenous species } \\
\text { [391]. }\end{array}$ \\
\hline $\begin{array}{c}\text { Branchiomma conspersum } \\
\text { (Ehlers, 1887) }\end{array}$ & Key West, Florida, USA & Floridian & Non-indigenous & Hawaii & ITS & $\begin{array}{c}\text { Reported from Hawaii } \\
{[185]}\end{array}$ \\
\hline $\begin{array}{l}\text { Branchiomma curtum } \\
\text { (Ehlers, 1901) }\end{array}$ & $\begin{array}{l}\text { Juan Fernández Island, } \\
\text { Chile }\end{array}$ & Juan Fernández & Not translocated & ? Mexican Caribbean & none & $\begin{array}{l}\text { Caribbean records may } \\
\text { be erroneous [391]. Both } \\
\text { syntypes of } B \text {. curtum } \\
\text { and Caribbean } \\
\text { specimens were } \\
\text { juveniles produced by } \\
\text { fission [392]. See } \\
\text { comments in [391]. } \\
\text { Common in the }\end{array}$ \\
\hline $\begin{array}{c}\text { Branchiomma luctuosum } \\
\text { (Grube, 1870) }\end{array}$ & Red Sea & Red Sea & Non-indigenous & Mediterranean, Brazil & none & $\begin{array}{c}\text { Common in the } \\
\text { Mediterranean as } \\
\text { Lessepsian migrant } \\
{[129,389,390,393-401]} \\
\text { and Brazil }[234,402]\end{array}$ \\
\hline $\begin{array}{c}\text { Desdemona ornata Banse, } \\
1957\end{array}$ & South Africa & Agulhas & ? Non-indigenous & $\begin{array}{l}\text { Iberian Peninsula, UK, } \\
\text { Marmara Sea, Portugal }\end{array}$ & none & $\begin{array}{c}\text { Reported as introduced } \\
\text { in Australia [403], Spain } \\
\text { [404], UK [405], } \\
\text { Marmara Sea [406], } \\
\text { Portugal [407] and the } \\
\text { Netherlands [408], but } \\
\text { types of D. ornata were } \\
\text { not examined. }\end{array}$ \\
\hline
\end{tabular}


Table 6. Cont

\begin{tabular}{|c|c|c|c|c|c|c|}
\hline Species & Type Locality & Presumed Origin & Category & $\begin{array}{c}\text { New Occurrences } \\
\text { (Outside of Expected } \\
\text { Natural Range) }\end{array}$ & Molecular Markers & Comments \\
\hline $\begin{array}{l}\text { Euchone limnicola Reish, } \\
1959\end{array}$ & $\begin{array}{c}\text { Los Angeles, California, } \\
\text { USA }\end{array}$ & $\begin{array}{l}\text { Warm Temperate } \\
\text { Northeast Pacific }\end{array}$ & ? Non-indigenous & Dunkerke, Australia & none & $\begin{array}{l}\text { Reported from Australia } \\
\text { by McArthur [409] and } \\
\text { included in Hewitt et al. } \\
\text { [380] based on McArthur } \\
\text { dissertation. Reported } \\
\text { by Guyonnet and Borg } \\
\text { [410] from the French } \\
\text { coast of North Sea. } \\
\text { Reported in Australian }\end{array}$ \\
\hline $\begin{array}{l}\text { Laonome calida Capa, } \\
2007\end{array}$ & Queensland, Australia & Unknown & ? Non-indigenous & $\begin{array}{c}\text { Australia (Queensland, } \\
\text { Northern Territory, } \\
\text { Western Australia), } \\
\text { ? Europe (the } \\
\text { Netherlands, Sea of } \\
\text { Azov, Baltic Sea, Mosel } \\
\text { River) }\end{array}$ & none & $\begin{array}{l}\text { in fully marine but also } \\
\text { estuarine conditions, in } \\
\text { both pristine and port } \\
\text { environments [68]. Bick } \\
\text { et al. [102] suggest that } \\
\text { European records belong } \\
\text { to Laonome xeprovala, not } \\
\text { L. calida. }\end{array}$ \\
\hline $\begin{array}{l}\text { Laonome elegans Gravier, } \\
1906\end{array}$ & Red Sea & Red Sea & ? Non-indigenous & East Mediterranean & none & $\begin{array}{l}\text { Listed in Zenetos et al. } \\
\text { [383]. Presence in the } \\
\text { Mediterranean area as } \\
\text { Lessepsian migrant } \\
\text { needs to be confirmed. }\end{array}$ \\
\hline $\begin{array}{c}\text { Laonome triangularis } \\
\text { Hutchings and Murray, } \\
1984\end{array}$ & $\begin{array}{c}\text { New South Wales, } \\
\text { Australia }\end{array}$ & $\begin{array}{l}\text { East Central Australian } \\
\text { Shelf }\end{array}$ & ? Non-indigenous & Turkey & none & $\begin{array}{l}\text { Reported as introduced } \\
\text { in Turkey [126]. }\end{array}$ \\
\hline $\begin{array}{l}\text { Laonome xeprovala Bick } \\
\text { and Bastrop in Bick et al. } \\
2018\end{array}$ & Estonia, Baltic Sea & Unknown & Non-indigenous & $\begin{array}{c}\text { the Netherlands, Sea of } \\
\text { Azov, Baltic Sea, Mosel } \\
\text { River }\end{array}$ & COI, 16S, $18 \mathrm{~S}$ & $\begin{array}{l}\text { Specimens from the } \\
\text { Baltic Sea, the } \\
\text { Netherlands and the Sea } \\
\text { of Azov possessed } \\
\text { identical genotypes, but } \\
\text { unknown origin [102]. } \\
\text { Confirmation that it is } \\
\text { not the same as L. calida } \\
\text { is needed. }\end{array}$ \\
\hline
\end{tabular}


Table 6. Cont

\begin{tabular}{|c|c|c|c|c|c|c|}
\hline Species & Type Locality & Presumed Origin & Category & $\begin{array}{c}\text { New Occurrences } \\
\text { (Outside of Expected } \\
\text { Natural Range) }\end{array}$ & Molecular Markers & Comments \\
\hline $\begin{array}{c}\text { Myxicola infundibulum } \\
\text { (Renier in Meneghini, } \\
\text { 1847) }\end{array}$ & Devon, UK & Northern European Seas & Non-indigenous & $\begin{array}{c}\text { Australia, ?North } \\
\text { America }\end{array}$ & COI, $16 \mathrm{~S}$ & $\begin{array}{l}\text { Analysed sequences of } \\
\text { specimens from } \\
\text { European and Australian } \\
\text { waters belong to same } \\
\text { species; sequences from } \\
\text { Maine showed some } \\
\text { differences [411]. }\end{array}$ \\
\hline $\begin{array}{c}\text { Parasabella fullo Grube, } \\
\text { 1878) }\end{array}$ & Northern Japan & $\begin{array}{c}\text { Temperate Northwest } \\
\text { Pacific }\end{array}$ & Non-indigenous & $\begin{array}{l}\text { Santa Barbara and San } \\
\text { Diego, California, USA }\end{array}$ & none & $\begin{array}{l}\text { Collected on ship hulls } \\
\text { in California, and a } \\
\text { resident population } \\
\text { appears to exist in the } \\
\text { region [412]. }\end{array}$ \\
\hline $\begin{array}{c}\text { Parasabella pallida Moore, } \\
1923\end{array}$ & California, USA & $\begin{array}{l}\text { Warm Temperate } \\
\text { Northeast Pacific }\end{array}$ & Not translocated & NA & none & $\begin{array}{l}\text { Included in the list of } \\
\text { translocated species by } \\
\text { mistake [294], as it was } \\
\text { described from } \\
\text { California [143] not the } \\
\text { Caribbean, as later fixed } \\
\text { in [73]. }\end{array}$ \\
\hline $\begin{array}{c}\text { Parasabella rugosa (Moore, } \\
\text { 1904) }\end{array}$ & $\begin{array}{c}\text { San Diego, California, } \\
\text { USA }\end{array}$ & $\begin{array}{l}\text { Warm Temperate } \\
\text { Northeast Pacific }\end{array}$ & Non-indigenous & Australia & none & $\begin{array}{l}\text { It was reported in } \\
\text { Australia near an } \\
\text { international port as sp. } \\
\text { cf. P. rugosa Capa and } \\
\text { Murray [73]. }\end{array}$ \\
\hline $\begin{array}{l}\text { Pseudobranchiomma } \\
\text { emersoni Jones, } 1962\end{array}$ & Port Jackson, Jamaica & $\begin{array}{c}\text { Tropical Northwestern } \\
\text { Atlantic }\end{array}$ & Non-indigenous & Australia & none & $\begin{array}{l}\text { As cf. P. emersoni in Capa } \\
\text { and Murray [74]. } \\
\text { As cf. P. orientalis in }\end{array}$ \\
\hline $\begin{array}{c}\text { Peudobranchiomma } \\
\text { orientalis (McIntosh, } \\
\text { 1885) }\end{array}$ & Hong Kong & Unknown & Non-indigenous & Australia & none & $\begin{array}{c}\text { Capa and Murray [74]. } \\
\text { Ethanol fixed specimens } \\
\text { are need for molecular } \\
\text { analysis. }\end{array}$ \\
\hline
\end{tabular}


Table 6. Cont

\begin{tabular}{|c|c|c|c|c|c|c|}
\hline Species & Type Locality & Presumed Origin & Category & $\begin{array}{c}\text { New Occurrences } \\
\text { (Outside of Expected } \\
\text { Natural Range) }\end{array}$ & Molecular Markers & Comments \\
\hline $\begin{array}{c}\text { Pseudobranchiomma } \\
\text { schizogenica } \\
\text { Tovar-Hernández and } \\
\text { Dean, } 2014\end{array}$ & La Paz, Mexico & $\begin{array}{c}\text { Tropical Northwestern } \\
\text { Atlantic }\end{array}$ & Non-indigenous & Australia, Galapagos & ITS, Cytb & $\begin{array}{c}\text { As cf. P. schizogenica in } \\
\text { Capa and Murray [74] } \\
\text { from Australia, also } \\
\text { reported in Galapagos } \\
\text { [183]. }\end{array}$ \\
\hline $\begin{array}{l}\text { Sabella spallanzanii } \\
\text { (Gmelin, 1791) }\end{array}$ & Malta & Mediterranean & Non-indigenous & Australia, New Zealand & $\begin{array}{c}\text { COI, H3, 18S, 28S, 16S, } \\
\text { ITS }\end{array}$ & $\begin{array}{c}\text { Considered an invasive } \\
\text { pest in Australia and } \\
\text { New Zealand } \\
{[202,364,370,413] .}\end{array}$ \\
\hline $\begin{array}{l}\text { Sabellastarte spectabilis } \\
\text { (Grube, 1878) }\end{array}$ & $\begin{array}{l}\text { Bohol, Masalac, } \\
\text { Philippines and } \\
\text { Singapore }\end{array}$ & Western Coral Triangle & ? Non-indigenous & $\begin{array}{c}\text { Sri Lanka, Solomon } \\
\text { Islands, Mauritius, } \\
\text { Japan, Taiwan, Hawaii, } \\
\text { Malaysia, Saipan, } \\
\text { Pakistan }\end{array}$ & COI, 16S & $\begin{array}{l}\text { Reports of accidental } \\
\text { introductions to Hawaii } \\
\text { [414-416] rely on invalid } \\
\text { morphological features } \\
\text { [70]. Evidence for wide } \\
\text { distribution exists [70]. }\end{array}$ \\
\hline $\begin{array}{c}\text { Terebrasabella } \\
\text { heterouncinata Fitzhugh } \\
\text { and Rouse, } 1999\end{array}$ & South Africa & Unknown & Non-indigenous & California, Chile & none & $\begin{array}{l}\text { Parasite of red abalone. } \\
\text { Reported from abalone } \\
\text { farms from California } \\
\text { and Chile [66,300-419]. }\end{array}$ \\
\hline $\begin{array}{l}\text { Ficopomatus enigmaticus } \\
\text { (Fauvel, 1923) }\end{array}$ & $\begin{array}{c}\text { France, native range is } \\
\text { unknown, likely } \\
\text { southerm Australia }\end{array}$ & Unknown & Non-indigenous & $\begin{array}{l}\text { Europe, New Zealand, } \\
\text { Japan, USA (both coasts), } \\
\text { Argentina, Tunisia, } \\
\text { Egypt, Côte d'Ivoire, } \\
\text { South Africa }\end{array}$ & Cytb, COI & $\begin{array}{c}\text { Reviewed by Dittmann } \\
\text { [420]. Styan et al. [204] } \\
\text { revealed three species } \\
\text { (not formally described) } \\
\text { with overlapping ranges } \\
\text { in Australia, one of } \\
\text { which is } \\
\text { morphologically distinct } \\
\text { from the other two. } \\
\text { Grosse et al. [421] found } \\
\text { two other species within } \\
\text { the complex Spain. }\end{array}$ \\
\hline
\end{tabular}


Table 6. Cont.

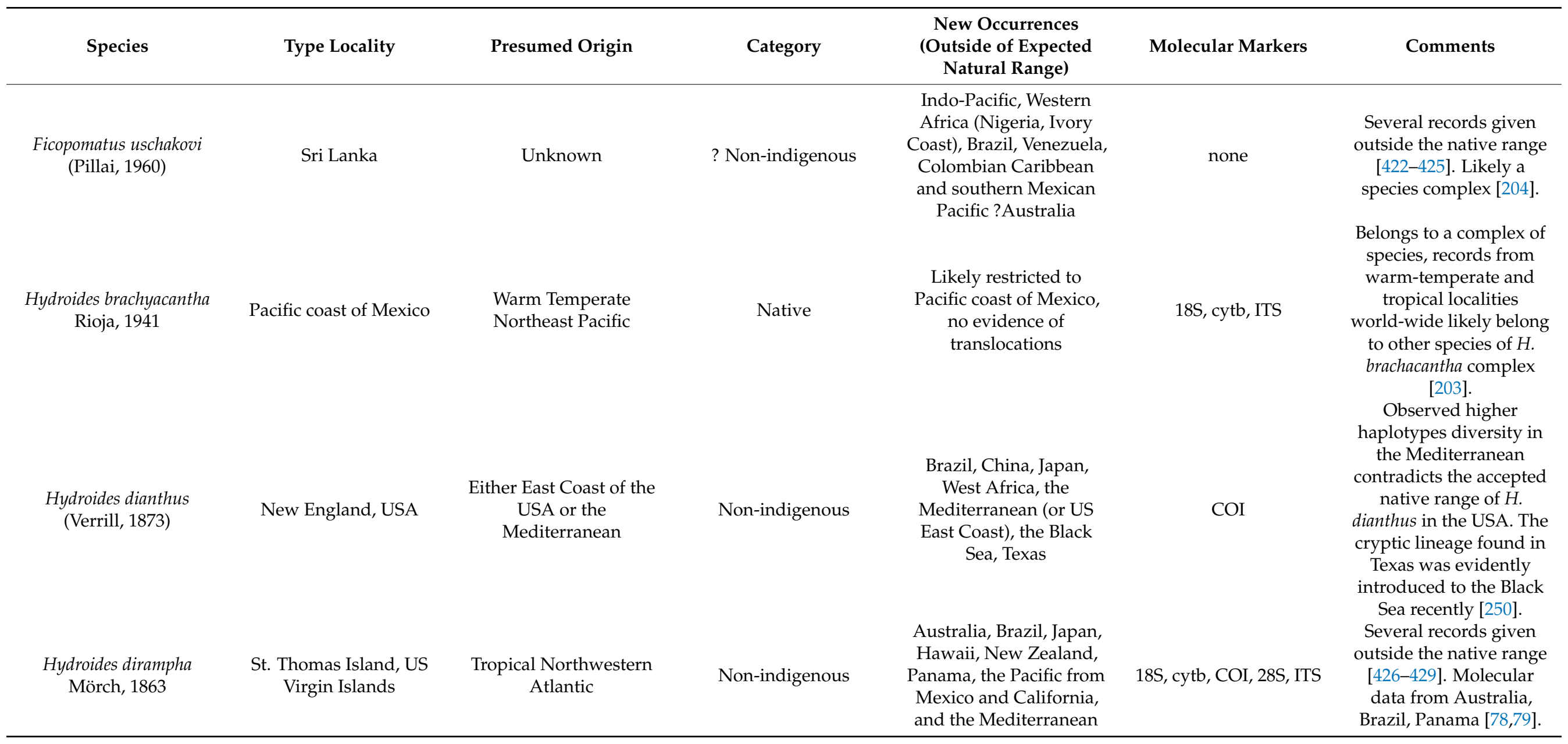


Table 6. Cont

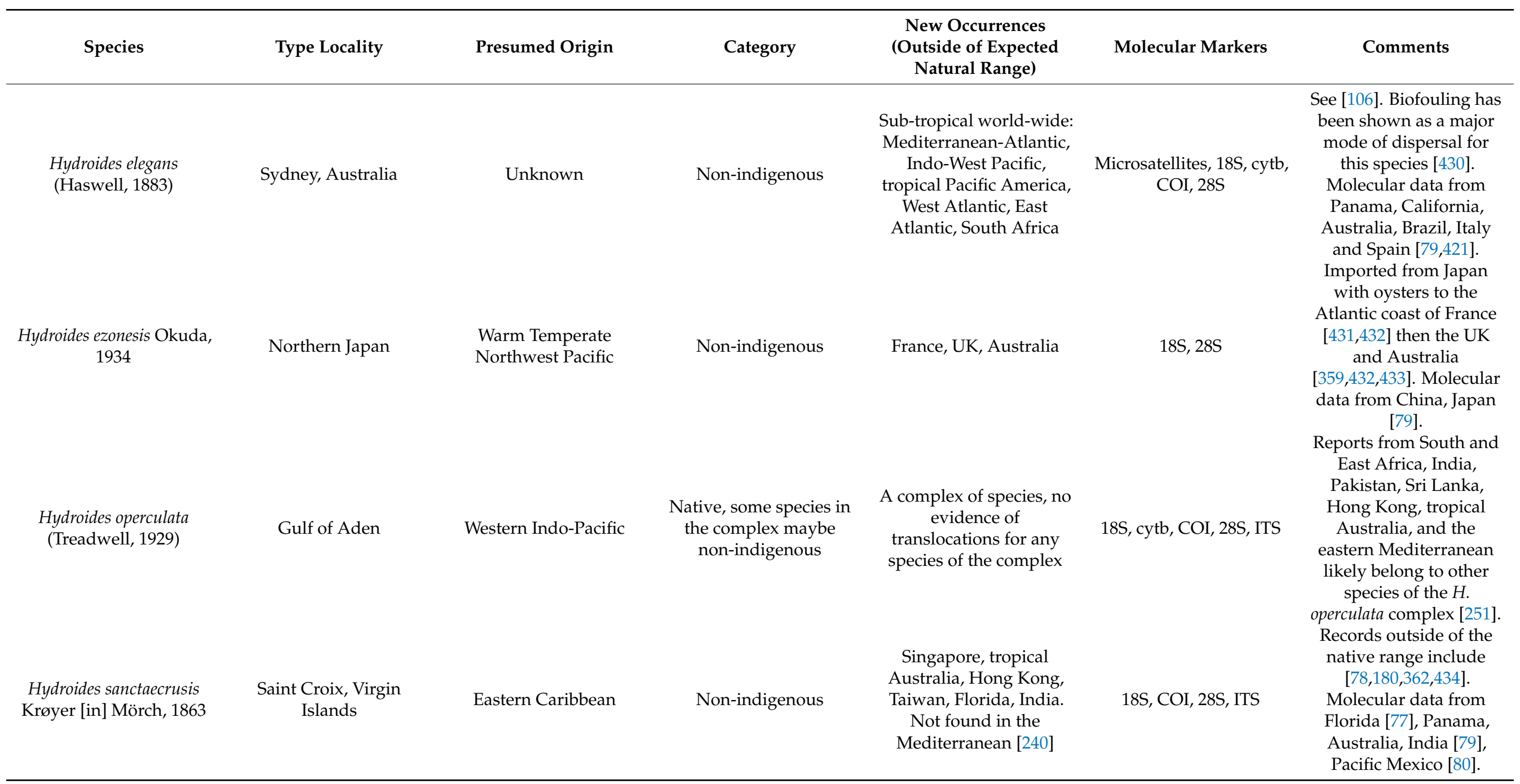


Table 6. Cont

\begin{tabular}{|c|c|c|c|c|c|c|}
\hline Species & Type Locality & Presumed Origin & Category & $\begin{array}{c}\text { New Occurrences } \\
\text { (Outside of Expected } \\
\text { Natural Range) }\end{array}$ & Molecular Markers & Comments \\
\hline $\begin{array}{l}\text { Spirobranchus kraussii } \\
\text { (Baird, 1865) }\end{array}$ & $\begin{array}{l}\text { Cape of Good Hope, } \\
\text { South Africa }\end{array}$ & Agulhas & $\begin{array}{l}\text { Native, some species in } \\
\text { the complex } \\
\text { non-indigenous, but not } \\
\text { S. kraussi }\end{array}$ & $\begin{array}{l}\text { Restricted to South } \\
\text { Africa, no evidence of } \\
\text { translocations }\end{array}$ & $18 \mathrm{~S}, \mathrm{cytb}$ & $\begin{array}{c}\text { Reports from } \\
\text { warm-temperate and } \\
\text { tropical localities in the } \\
\text { Indo-Pacific and } \\
\text { Mediterranean Sea } \\
\text { belong to other species } \\
\text { of } S . \text { kraussii complex } \\
{[84,193] .}\end{array}$ \\
\hline $\begin{array}{l}\text { Spirobranchus tetraceros } \\
\quad(\text { Schmarda, 1861) }\end{array}$ & NSW, Australia & $\begin{array}{l}\text { East Central Australian } \\
\text { Shelf }\end{array}$ & $\begin{array}{l}\text { Native, some species in } \\
\text { the complex likely } \\
\text { non-indigenous, but not } \\
\text { S. tetraceros }\end{array}$ & $\begin{array}{l}\text { Likely restricted to } \\
\text { south-eastern Australia, } \\
\text { no evidence of } \\
\text { translocations. }\end{array}$ & cytb & $\begin{array}{l}\text { Reports from } \\
\text { warm-temperate and } \\
\text { tropical localities } \\
\text { world-wide belong to } \\
\text { other species of the } S \text {. } \\
\text { tetraceros complex. At } \\
\text { least one of these species } \\
\text { was introduced and } \\
\text { established in the } \\
\text { Mediterranean [252]. }\end{array}$ \\
\hline
\end{tabular}


One of the best examples of a sabellid with the invasive status confirmed through a combination of morphological and genetic data is Sabella spallanzanii. This large conspicuous Mediterranean native was introduced to Australia in 1965 and to New Zealand in $2008[364,435,436]$. Analyses of COI sequences from the native and non-indigenous populations proved that the New Zealand incursion originated from Australia rather than from the Mediterranean [370]. Other examples of sabellids with invasive status (but ofunknown origin) confirmed with DNA analyses are Parasabella crassichaeta Capa and Murray, 2015 and Pseudobranchiomma cf. schizogenica Tovar-Hernández and Dean, 2014, reported from both Hawaii and Australia [73,74]. Out of seven nominal species of the serpulid genus $\mathrm{Hy}$ droides reported as translocated outside of their natural range, five are confirmed invaders (Table 6). One of them, H. elegans, is the best-known cryptogenic polychaete, reported from most sub-tropical locations world-wide [110], and biofouling as the major mode of its dispersal was supported by DNA data [430]. Ficopomatus enigmaticus is another cryptogenic serpulid, because, although it was described from France, its native range is enigmatic (hence the name), likely to be southern Australia [420]. This typical species has invaded warm-temperate estuaries world-wide, as confirmed by DNA studies [204,437,438].

Ficopomatus uschakovi (Pillai, 1960), described from Sri Lanka, a tropical species with supposedly wide distribution in Indo-Pacific, was recently reported as introduced to South America [422-425]. The invasive status of the species has not been examined with DNA, but preliminary molecular data (Kupriyanova unpubl.) suggest that this taxon is a complex of species. Two nominal Hydroides species, H. brachyacantha Rioja, 1941 and H. operculata (Treadwell, 1929), are examples of complexes of morphologically similar species $[180,251]$. Similarly, the invasive status attributed to serpulids Spirobranchus kraussii (Baird, 1865) and S. tetraceros (Schmarda, 1861) [365,439] is unjustified, as both are members of species complexes [84,193,252].

The Mediterranean Sea leads the rank when it comes to reported introductions, with 13 serpulid and 10 sabellid non-indigenous species reported, mainly as a result of Lessepsian migration from the Red Sea $[125,365,440,441]$. In this region, 11 species of sabellids and serpulids, mainly of the genera Branchiomma, Ficopomatus, and Hydroides, have been listed among the top 100 worst invasive species, based on their economic and ecological impacts [442]. However, taxonomic and invasive status of many of these taxa needs to be revised.

\subsection{Fanworms Are Important: Some Applications}

\subsubsection{Nuisance Fouling Species}

Several serpulid species, predominantly of the genera Hydroides, Ficopomatus, and Spirobranchus, are capable of colonizing a wide range of natural and artificial substrates and settling gregariously, which makes them economically and ecologically important fouling nuisance species.

Serpulid foulers constitute a significant financial burden to due to costs associated with the removal of tubes from artificial structures. Millions of dollars are spent annually to prevent the fouling of marine organisms, especially of Hydroides, on human-made structures [443]. Dense tube aggregates attach to underwater seawater intake pipes of power plants reducing water flow and causing blockages. Fouled docks require cleaning maintenance in harbours around the world. Fouling interferes with navigation and shipping industries by decreasing ship speed, while increasing the weight and drag of buoys $[444,445]$.

In marine aquaculture the key impact is the direct fouling of stock causing physical damage, biological competition and environmental modification, while infrastructure, such as aquaculture nets and cages, is also damaged. The conservative estimates of economic loss to the aquaculture industry are $5-10 \%$ of production costs attributed to biofouling [446].

Manayunkia speciosa and/or M. occidentalis (see [216]) are obligate hosts of the myxozoan parasites Ceratonova shasta and Parvicapsula minibicornis, which cause ceratomyxosis in salmon and trout in North America [267,268,447]. Management actions, such as flow 
manipulations to increase the mortality of $M$. speciosa and disturbance of its habitat, have been implemented [268].

\subsubsection{Non-Indigenous and Invasive Species}

Non-native to a region species translocated to another region can expand and have significant impact on human health, economic interests or environmental values. Such translocations of fouling species of Sabellida are well documented (e.g., [448-452]). Countries around the world have established biosecurity systems, aimed to prevent the introduction and/or spread of non-indigenous organisms. Some Sabellida have been listed in individual countries' Laws and Regulations, indicating its status as unwanted non-indigenous species (invasive, pests, parasites, pathogens). For example, in New Zealand, Sabella spallanzanii has been registered as a notifiable organism, subject to targeted surveillance work, including study of population dynamics and reproduction, under the New Zealand Biosecurity Act 1993 [364]. In Australia, non-indigenous marine species already found and those not yet found but have demonstrated significant impacts elsewhere are ranked according to their invasive impact and potential. For example, S. spallanzanii is regarded as a high impact, notifiable invasive species, while Hydroides dirampha Mörch, 1863, H. dianthus, $H$. sanctaecrucis Krøyer in Mörch, 1863, H. ezoensis Okuda, 1934 are listed as medium or low priority species [433]. In Mexico, sabellids Branchiomma bairdi (McIntosh, 1885) and Terebrasabella heterouncinata and six serpulids (Ficopomatus enigmaticus, F. miamiensis (Treadwell, 1934), F. uschakovi, Hydroides elegans, H. bispinosa Bush, 1910 and H. dirampha) are regulated under the Diario Oficial de la Federación [453]. Ficopomatus enigmaticus is the only annelid registered in the Spanish Catalogue of Exotic Invasive Species [421]. In Brazil, the only species of Sabellida reported as invasive is Branchiomma luctuosum (Grube, 1870) [401].

\subsubsection{Indicators of Pollution}

Manayunkia speciosa is an indicator of moderate organic pollution, but is intolerant of severe pollution or anoxic sediments $[447,454,455]$. Decrease of the organic content of the sediment from $1.8 \%$ to $1.0 \%$ leads to reduction in abundance of its congener, M. aestuarina, from 16000 to 6000 ind. ${ }^{2}$ in the Baltic Sea [262]. Euchonoides moeone was proposed as an indicator of sediment organic enrichment in a sewage outfall in Hawaii [279].

Sabella spallanzanii can trap anthropogenic micro-particles and glue these to their tubes, and it has been proposed as an indicator of microlitter pollution in sheltered and polluted environments such as ports [456]. Larvae of Hydroides elegans have been used as indicators for biomonitoring and ecotoxicology tests (e.g., [457-459]).

Some sabellids and serpulids have been suggested as bioindicators of heavy metal pollution. For example, the tube of Sabella spallanzanii is an important compartment in metal retention and suitable for evaluation of the pollution by traced elements [460], while Branchiomma bairdi and B. luctuosum, invasive sabellids in the Mediterranean, can accumulate high concentrations of arsenic (As), cadmium (Cd), chromium ( $\mathrm{Cr}$ ) and lead $(\mathrm{Pb})$, considered to be priority toxic or ubiquitous persistent, bioaccumulative and toxic (PBT) substances under the EU Water Framework Directive [461]. Some studies have focused on the effects of heavy metals on larval development and metamorphosis using serpulid larvae (Hydroides elegans: [462,463]); Galeolaria caespitosa: [464]).

\subsubsection{Bioremeditators}

As suspension feeders, Sabella spallanzanii, Branchiomma luctuosum and B. bairdi have been tested as bioremediators for aquaculture waste-water treatment in polluted coastal areas $[273,274,465-470]$. However, these three taxa are invasive in some areas, and may pose a threat to native ecosystems. Nevertheless, the use of non-indigenous species as bioremediator may allow to transform a potential risk into a benefit, with high potential commercial gain and economic feasibility [470]. Due to their important role in organic sediment bioremediation, the Food and Agriculture Organization of the United Nations 
(FAO, Roma, Italy) recommended Sabella as one of organisms with most potential for the development of integrated multi-trophic aquaculture systems [471].

Ficopomatus enigmaticus is a dominant species in estuaries and lagoons, where it can affect the community structure and contribute to the invertebrate biomass [472,473]. Due to its ability to build extensive reefs, F. enigmaticus is considered an ecosystem engineer that can modify estuarine ecosystem, changing water flow, sedimentation rates, and creating a structured hard substrate habitat in a soft-sediment environment. Large aggregations of $F$. enigmaticus remove suspended particulate matter, reduce excess nutrient loads and improve oxygen levels in enclosed waters, thereby improving the water quality and environmental conditions for other benthic species (reviewed in [420]). Davies et al. [474] stressed that because of the fundamental role F. enigmaticus played in the maintenance of water quality of an enclosed system near Cape Town, South Africa, eradication of this non-indigenous species should not be a management option.

\subsubsection{Models Organisms in Research}

Sabellids are used as models in regeneration biology, most notably in studies examining the developmental basis and functional ecology of regeneration [222,475-477]. Members of the genus Myxicola are known for the giant axon [478] that directly innervates the worm's muscles, presumably aiding in super-fast retraction into the tubes [479]. The outsized nerves make this species a model organism for studies of neuroanatomy, neuroactivity and electrophysiology [480-482]. Myxicola's giant axons were also used for testing the effects of the anticonvulsant Carbamazepine on the ionic conductance [483]. Moreover, the mucus of Myxicola infundibulum (Renier in Meneghini, 1847), with natural antibacterial and antioxidant compounds, showed potential for drug prospection [470].

Hydroides elegans is easily adapted for laboratory research because of its rapid generation time (three weeks) and ease of propagation. The adults spawn and eggs easily fertilise, their larvae become metamorphically competent in several days and readily settle in the laboratory. Thus, H. elegans has been declared an important model organism [484] and has been used routinely during last two decades in hundreds of experimental embryological, larval ecology and biofouling studies, including tests of newly formulated marine coatings (e.g., [485-490]). Other Hydroides species, such as H. ezoensis and H. dianthus, have also acted as model organisms for larval ecology research (e.g., studies of mechanisms of gregarious settlement by [491-493]. Spirobranchus lamarcki (Quatrefages, 1866) has provided an important model system for molecular and embryological work, including studies on the organization and expression of its developmental genes (e.g., [494-497]). Recently $H$. elegans and $S$. triqueter have served as models in ocean acidification and biomineralization research (e.g., [498-500]).

\subsubsection{Objects of Ornamental Trade}

Sabellida includes some of the most beautiful marine invertebrates due to their colourful radiolar crowns. They are listed among the ten most imported ornamental invertebrates [501]) and are amongst the most photographed polychaetes found in marine guides and featured on postcards, stamps, calendars, T-shirts and even tattoos. Largest sabellids (Anamobaea, Bispira, Notaulax, Sabella and Sabellastarte) and serpulids such as Christmas tree worms (Spirobranchus) and coco worms (Protula) are popular in the aquarium trade. The vast majority of ornamental sabellids and serpulids are tropical species, although a market for cold-water species has been growing [502,503]. Efforts to culture sabellids (e.g., Sabellastarte spectabilis (Grube, 1878) [504-506], Sabella pavonina Savigny, 1822 [270,507] and Bispira brunnea (Treadwell, 1917) [508] are well under way. Aquaculture can provide environmental benefits by reducing collecting pressure on highly traded species.

\subsection{Future Perspectives in Fanworm Research}

As it is clear from this review, knowledge of Sabellida biodiversity is incomplete and the reported species numbers appear to be an underestimation of the true diversity. 
This review highlights that some of the lesser known coastal and continental shelf areas including Hudson complex, the Atlantic coast of South America (especially the tropical Atlantic region, excluding the Caribbean Sea), the coastlines along the Arabic Sea and Gulf of Bengal, and the Far East of Russia. However, Africa, with the exception of South Africa and Morocco, is by far the most neglected continent when it comes to taxonomic studies.

More surveys into deep-sea (abyssal and hadal), chemosynthesis-based (hydrothermal vents, methane seeps and organic falls) and freshwater habitats are needed for a better understanding of the Sabellida diversity and adaptations to these habitats. The fact that undescribed species have been collected in recent deep-sea cruises along several worldwide regions (e.g., $[284,509,510])$ provides evidences for deep sea fanworms still awaiting to be discovered. Studies of symbiotic/commensal relationships with other organisms, e.g., molluscs, corals, sponges, or examinations of bacterial microbiomes may reveal not only new taxa, but also new ecological relationships and trophic networks (e.g., [284,490]).

Importantly, the diversity of some remote areas, including deep sea environments, is poorly known not only because of the obvious logistical difficulties with collecting, but also due the insufficient number of experts and their unbalanced distribution across the globe known as 'taxonomic impediment' (e.g., [94,511]). We need to train and sustain more systematists able to discover, describe, identify and classify species and also to increase efforts directed to manage and curate existing research collections [355].

As many more species are yet to be discovered, either in the field or in museum collections, particular attention should be paid to setting a high standard for the new species descriptions, which would include use of modern microscopic techniques (e.g., SEM, Phase Contrast), assessment of intra- and interspecific variability, and preparation of quality informative illustrations (digital drawings and high-quality digital photographs of stained fixed or live specimens, when possible). Exploration of both new characters, e.g., ultrastructure of calcareous serpulid tubes that proved useful for species delimitation $[107,227,512]$, and new techniques to examine existing morphological characters, e.g., tomography and 3D reconstructions (e.g., [237]) should significantly improve species descriptions in the future and aid species delimitations.

Although multivariate morphometrics have been used to analyse differences among annelid species and populations (e.g., [513,514]), this technique is not very common for species delimitation because body shapes of these soft-bodied organisms vary depending on the fixation or anaesthetization methods [234]. We suggest that application of morphometrics to chaetal or opercular traits should be explored. However, regardless of availability DNA data, morphological studies must include statistical assessment of intraspecific variability and its sources (such as size-dependent, ontogenetic, environmental) (e.g., $[72,278,515])$.

Understanding of true species diversity of Sabellida requires world-wide revisionary studies of existing species and their distribution ranges. As early species descriptions are often very short and sometimes poorly illustrated, further re-descriptions of older species (especially described before mid-20th century) are needed, ideally based on topotypical material (as, e.g., done for serpulid Spirobranchus kraussii by Simon et al. [193]). For the species with lost or lacking types, neotypes should designated (e.g., as for Pseudopotamilla reniformis (Bruguière, 1789) by Knight-Jones et al. [111]), preferably accompanied by DNA sequence data (e.g., as done for Hydroides brachyacantha by Sun et al. [197]. It is imperative that the type material (holotype, type series, additional specimens showing intraspecific variability, and DNA extractions) is always deposited in properly curated permanent museum collection(s) where it is maintained in optimal conditions [516].

Contrary to previous conceptions that the ocean has no boundaries and that polychaetes more often than other organisms have cosmopolitan distributions [327], it now became clear that the genetic and species diversity of marine invertebrates is highly structured geographically and significant species diversity is hidden in former 'cosmopolitan polychaete species'. Therefore, resolution of 'cosmopolitan species' should be one of the main goals of revisionary studies of Sabellida. This goal is only achieved with application 
of fast-developing molecular tools such as DNA sequencing and genomics/transcriptomics. Molecular tools and analytical methods are indispensable to further improve our understanding of the species diversity, but also to trace the pathways and origins of invasive species, to determine biogeographic boundaries between species, and to provide reliable phylogenic hypotheses. Robust well-resolved phylogenies with significant taxon coverage using transcriptome and mitochondrial genome data are important to address important character evolution questions (e.g., photoreceptor evolution and evolution of the reproductive and larval strategies in Sabellidae and Serpulidae). Finally, in the future molecular identification of species by non-specialists might replace morphology-based identifications only if reliable databases of reference sequences supported by voucher specimen depositories are built.

Supplementary Materials: The following are available online at https:/ /www.mdpi.com/1424-281 8/13/3/130/s1, Table S1: Fabriciidae, species and type localities; Table S2: Sabellidae, species and type localities; Table S3: Serpulidae, species and type localities.

Author Contributions: Conceptualization, M.C. and M.A.T.-H.; validation, M.C., E.K., A.B., J.M.d.M.N. and M.A.T.-H.; writing—original draft preparation M.C., E.K., A.B., J.M.d.M.N. and M.A.T.-H.; writingreview and editing, M.C., E.K., A.B., J.M.d.M.N. and M.A.T.-H.; visualization, M.C., E.K., A.B., J.M.d.M.N. and M.A.T.-H.; coordination, M.C., E.K., A.B., J.M.d.M.N. and M.A.T.-H.; funding acquisition, M.C. and E.K. All authors have read and agreed to the published version of the manuscript.

Funding: M.C. was funded by the Ramón y Cajal program (RYC-2016-20799) funded by Spanish MINECO, Agencia Estatal de Investigación, Comunidad Autónoma de las Islas Baleares and the European Social Fund. EK was funded by the Australian Biological Research Study (ABRS) grant RG18-21. J.M.M.N. was funded by a productivity grant from “CNPq-Conselho Nacional de Desenvolvimento Científico e Tecnológico, Brazil, level 2".

Data Availability Statement: Not applicable.

Acknowledgments: We would like to thank Mike Bok (Lund University, Sweden), Alexander Semenov (Moscow University, Russia), Greg Rouse (Scripps Institution of Oceanography, UCSD, USA), Graeme Christie (Australia), Anna Dietrich (Institute for Applied Ecosystem Research, Germany), Vitaly Syomin (P.P. Shirshov Institute of Oceanology), Humberto Bahena (Ecosur, Mexico), Eunice Wong (University of Texas at Austin, USA), Alexander Rzhavsky (Russian Academy of Sciences, Russia), Orlemir Carrete (Universidade de São Paolo, Brazil)and Floor Verbiest (Rijksmuseum van Natuurlijke Historie, Leiden) for letting us use some their fantastic pictures of live animals. Laura C. Armendáriz (Instituto de Limnología “Dr Raúl A. Ringuelet”, CONICET UNLP, Argentina) and Sue Lindsay (Macquarie University) provided with SEM micrographs. Alisson Ricardo da Silva (Museu da Casa Brasileira, Brazil), helped with the elaboration of the figures. We appreciate Geoff Read (NIWA New Zealand) for updating WoRMS and also Vollrath Wiese (Haus der Natur, Cismar) for helping us to clarify identity of Sabella species described by Gmelin. Further thanks are due to the publisher De Gruyter for permission to use the following images from chapter 7.4.8 Fabriciidae Rioja, 1823, from Handbook for Zoology, vol. 3 (Eds. G. Purschke, M. Böggemann and W. Westheide), De Gruyter GmbH, Berlin/Boston, 2021: 7.4.8.1A; 7.4.8.2 A, C; 7.4.8.6 D. We appreciate helpful comments from three anonymous reviewers.

Conflicts of Interest: The authors declare no conflict of interest.

\section{Appendix A}

Fabriciidae and Sabellidae species with doubtful identity requiring further investigation (inquirenda), indeterminable or incorrect assignation.

Fabriciidae

1. Manayunkia siaukhu Annenkova, 1938 inquirenda. Based on the description, M. siaukhu has pygidial eyes [517] and thus does not fulfill diagnostic features for the genus.

Sabellidae

2. Clymeneis Rathke, 1843 inquirenda 
Clymeneis and its type species Clymeneis stigmosa Rathke, 1843 are of doubtful identity requiring further investigation. Description was based in specimens inquirenda (?) apparently without crown and types have not been found. It has not been reported over more than a century, but recently mentioned in the paper about original specimens and type localities of early described polychaete species from Norway [518].

3. Sabella aculeata Gmelin in Linnaeus, 1788. Insecta: Trichoptera.

4. Sabella ammonita Gmelin in Linnaeus, 1788. Insecta: Trichoptera.

5. Sabella arenaria Montagu, 1803 indeterminable

Described based on the tube only, the worm is unknown [42] (pp. 552).

6. Sabella arundinacea Gmelin in Linnaeus, 1788. Insecta: Trichoptera.

7. Sabella clavata Gmelin in Linnaeus, 1788. Insecta: Trichoptera.

8. Sabella compressa Montagu, 1803 indeterminable

Original description was based only in the tube. Hartman [325] (pp.559) suggested that the tube is perhaps from a pectinariid.

9. Sabella conica Gmelin in Linnaeus, 1788. Insecta: Trichoptera.

10. Sabella corticalis Gmelin in Linnaeus, 1788. Insecta: Trichoptera.

11. Sabella dimidiata Gmelin in Linnaeus, 1788. Insecta: Trichoptera.

12. Sabella flabellata Savigny, 1820 inquirenda

Declared as inquirenda by Knight-Jones and Perkins [337] (pp. 398).

13. Sabella fixa Gmelin in Linnaeus, 1788. Insecta: Trichoptera.

14. Sabella grossa Baird, 1865 inquirenda

Declared as inquirenda by Knight-Jones and Mackie [338] (pp. 2296).

15. Sabella helicina Gmelin in Linnaeus, 1788. Insecta: Trichoptera.

16. Sabella nigra Gmelin in Linnaeus, 1788. Insecta: Trichoptera.

17. Sabella sabulosa Gmelin in Linnaeus, 1788. Insecta: Trichoptera.

18. Sabella setiformis Montagu, 1803 indeterminable

The tube was the only structure described, the worm is unknown [519] (pp.553).

19. Sabella stagnalis Gmelin in Linnaeus, 1788. Insecta: Trichoptera.

20. Sabella subcylindrica Montagu, 1803 indeterminable

Only the tube was described, animal unknown [519] (pp. 552-553).

21. Sabella teredula Chiereghini in Siebold, 1850 indeterminable

Only the tube was described [520] (pp. 369).

22. Sabella trigona Chiereghini in Siebold, 1850 indeterminable

Only the tube was described [520] (pp. 369).

23. Sabella uncinata Gmelin in Linnaeus, 1788. Insecta: Trichoptera.

24. Sabella vegetabilis Gmelin in Linnaeus, 1888. Insecta: Trichoptera.

25. Sabella zonalis Stimpson, 1854 inquirenda

Declared inquirenda by Knight-Jones and Perkins [337] (pp. 405).

\section{References}

1. Kupriyanova, E.K.; Rouse, G.W. Yet another example of paraphyly in Annelida: Molecular evidence that Sabellidae contains Serpulidae. Mol. Phylogenet. Evol. 2008, 46, 1174-1181. [CrossRef]

2. Capa, M.; Hutchings, P.; Aguado, M.T.; Bott, N.J. Phylogeny of Sabellidae (Annelida) and relationships with other taxa inferred from morphology and multiple genes. Cladistics 2011, 27, 449-469. [CrossRef]

3. Tilic, E.; Sayyari, E.; Stiller, J.; Mirarab, S.; Rouse, G.W. More is needed-thousands of loci are required to elucidate the relationships of the 'Flowers of the Sea' (Sabellida, Annelida). Mol. Phylogenet. Evol. 2020, 151, 106892. [CrossRef]

4. Bick, A. Fabriciidae Rioja, 1923. In Handbook of Zoology Annelida, Volume 3: Pleistoannelida, Sedentaria III and Errantia I; Purschke, G., Westheide, W., Böggemann, M., Eds.; De Gruyter: Berlin, Germany; Boston, MA, USA, 2021; pp. 1-33. 
5. Savigny, J.-C. Systèmes des Annélides, Principalement de Celles des Côtes de l'Égypte et de la Syrie, Offrant les Caractères tant Distinctifs que Naturels des Ordres, Familles et Genres, Avec la Description des Espèces Système des Annelides (I); Commission des sciences et arts d'Egypte: Paris, France, 1822; Volume 1, pp. 1-128.

6. Burmeister, H. Handbuch Der Naturgeschichte. Zum Gebrauch bei Voresungen; Zweite Abt. Zoologie.: Berlin, Germany, 1837; pp. 1-858.

7. Grube, A.E. Die Familien der Anneliden. Archiv Für Naturgeschichte 1850, 16, 249-364.

8. Grube, A.E. Beschreibungen Einiger von Georg Ritter von Frauenfeld Gesammelter Anneliden und Gephyreen des Rothen Meeres. Verhandlungen der Kaiserlich Königlichen Zoologisch-Botanischen Gesellschaft in Wien 1868, 18, 629-650.

9. Malmgren, A.J. Nordiska Hafs-Annulater. Öfversigt af Königlich Vetenskapsakademiens Förhandlingar 1866, 22, 355-410.

10. Hatschek, B. System Der Anneliden, ein vorläufiger Bericht. Sitzungsberichte des Deutschen NaturwissenschaftlichMedicinischen Vereines für Böhmen"Lotos“ in Prag. Neue Folge 1893, 13, 123-126.

11. Dales, R.P. The nature of the pigments in the crown of sabellid and serpulid polychaetes. J. Mar. Biol. Assoc. UK 1962, 42, 259-274. [CrossRef]

12. Fauchald, K. The polychaete worms. Definitions and keys to the orders, families and genera. Nat. Hist. Mus. LA County Sci. Ser. 1977, 28, 1-188.

13. Fauchald, K.; Rouse, G.W. Polychaete systematics: Past and present. Zool. Scr. 1997, 26, 71-138. [CrossRef]

14. Andrade, S.C.S.; Novo, M.; Kawauchi, G.Y.; Worsaae, K.; Pleijel, F.; Giribet, G.; Rouse, G.W. Articulating "Archiannelids": Phylogenomics and annelid relationships, with emphasis on meiofaunal taxa. Mol. Biol. Evol. 2015, 32, 2860-2875. [CrossRef] [PubMed]

15. Weigert, A.; Bleidorn, C. Current status of annelid phylogeny. Org. Divers. Evol. 2016, 16, 345-362. [CrossRef]

16. Helm, C.; Bok, M.J.; Hutchings, P.; Kupriyanova, E.; Capa, M. Developmental studies provide new insights into the evolution of sense organs in Sabellariidae (Annelida). BMC Evol. Biol. 2018, 18, 149-162. [CrossRef] [PubMed]

17. Wilson, D.P. The development of the sabellid Branchiomma vesiculosum. J. Cell Sci. 1936, 78, 534-603.

18. Berrill, N. Functional morphology and development of segmental inversion in sabellid polychaetes. Biol. Bull. 1977, 153, 453-467. [CrossRef]

19. Smith, R.S. Relationships within the Order Sabellida (Polychaeta). Ophelia Suppl. 1991, 5, 249-260.

20. Bartolomaeus, T. Structure and formation of thoracic and abdominal uncini in Fabricia stellaris (Müller, 1774)-implication for the evolution of Sabellida (Annelida). Zool. Anz. J. Comp. Zool. 2002, 241, 1-17. [CrossRef]

21. Kieselbach, D.; Hausen, H. Chaetal arrangement provides no support for a close relationship of Sabellidae and Sabellariidae (Annelida). J. Morphol. 2008, 269, 104-117. [CrossRef] [PubMed]

22. Capa, M.; Hutchings, P.; Peart, R. Systematic revision of Sabellariidae (Polychaeta) and their relationships with other polychaetes using morphological and DNA sequence data: Systematics of Sabellariidae. Zool. J. Linn. Soc. 2012, 164, 245-284. [CrossRef]

23. Capa, M.; Parapar, J.; Hutchings, P. Phylogeny of Oweniidae (Polychaeta) based on morphological data and taxonomic revision of Australian fauna: Oweniid phylogeny and Australian fauna. Zool. J. Linn. Soc. 2012, 166, 236-278. [CrossRef]

24. Capa, M.; Giangrande, A.; Nogueira, J.M.M.; Tovar-Hernández, M.A. Sabellidae Latreille, 1825. In Handbook of Zoology, Annelida, Volume 2: Pleistoannelida, Sedentaria II; Purschke, G., Böggemann, M., Westheide, W., Eds.; De Gruyter: Berlin, Germany, 2019; pp. 164-212.

25. Capa, M.; Hutchings, P. Sabellariidae Johnston, 1865. In Handbook of Zoology, Annelida, Volume 2: Pleistoannelida, Sedentaria II; Purschke, G., Böggemann, M., Westheide, W., Eds.; De Gruyter: Berlin, Germany, 2019; pp. 144-163.

26. Capa, M.; Parapar, J.; Hutchings, P.; Mortimer, K. 4. Palaeoannelida. Annelida; Purschke, G., Böggemann, M., Westheide, W., Eds.; De Gruyter: Berlin, Germany, 2019; pp. 91-132. ISBN 978-3-11-029158-2.

27. Huang, D.; Fitzhugh, K.; Rouse, G.W. Inference of phylogenetic relationships within Fabriciidae (Sabellida, Annelida) using molecular and morphological data. Cladistics 2011, 27, 356-379. [CrossRef]

28. Weigert, A.; Helm, C.; Meyer, M.; Nickel, B.; Arendt, D.; Hausdorf, B.; Santos, S.R.; Halanych, K.M.; Purschke, G.; Bleidorn, C.; et al. Illuminating the base of the annelid tree using transcriptomics. Mol. Biol. Evol. 2014, 31, 1391-1401. [CrossRef]

29. Struck, T.H.; Golombek, A.; Weigert, A.; Franke, F.A.; Westheide, W.; Purschke, G.; Bleidorn, C.; Halanych, K.M. The evolution of annelids reveals two adaptive routes to the interstitial realm. Curr. Biol. 2015, 25, 1993-1999. [CrossRef]

30. WoRMS 2020, Sabellida. Available online: http://www.marinespecies.org/aphia.php?p=taxdetails\&id=882 (accessed on 2 March 2021).

31. Spalding, M.D.; Fox, H.E.; Allen, G.R.; Davidson, N.; Ferdaña, Z.A.; Finlayson, M.; Halpern, B.S.; Jorge, M.A.; Lombana, A.; Lourie, S.A.; et al. Marine ecoregions of the World: A bioregionalization of coastal and shelf areas. BioScience 2007, 57, 573-583. [CrossRef]

32. Udvardy, M.D. A Classification of the Biogeographical Provinces of the World; IUCN Occasional Paper 18: Morges, Switzerland, 1975; pp. 1-49.

33. Olson, D.M.; Dinerstein, E.; Wikramanayake, E.D.; Burgess, N.D.; Powell, G.V.; Underwood, E.C.; D'amico, J.A.; Itoua, I.; Strand, H.E.; Morrison, J.C. Terrestrial ecoregions of the world: A new map of life on Earth a new global map of terrestrial ecoregions provides an innovative tool for conserving biodiversity. BioScience 2001, 51, 933-938. [CrossRef]

34. GBIF. 2020. Available online: https://www.gbif.org/es/ (accessed on 3 March 2021).

35. NCBI. 2020. Available online: https:/ / www.ncbi.nlm.nih.gov (accessed on 3 March 2021). 
36. Ratnasingham, S.; Hebert, P.D.N. BOLD: The Barcode of Life Data System (http://www.barcodinglife.org). Mol. Ecol. Notes 2007, 7, 355-364. [CrossRef]

37. Rafinesque, C.S. Analyse de la Nature ou Tableau de l'Universe et Des Corps Organize; De l'imprimerie de Jean Barravecchia: Palermo, Italy, 1815.

38. Chamberlin, R.V. The Annelida Polychaeta. Mem. Mus. Comp. Zool. 1919, 48, 1-518.

39. Rioja, E. Estudio sistemático de las especies Ibéricas del Suborden Sabelliformia. Trab. Mus. Nac. Cien. Nat. (Ser. Zool.) 1923, 48, $1-144$.

40. Pillai, G. Studies on a collection of spirorbids from Ceylon, together with a critical review and revision of spirorbid systematics and an account of their phylogeny and zoogeography. Ceylon J. Sci. (Biol. Sci.) 1970, 8, 100-172.

41. Ten Hove, H.A. Towards a phylogeny in serpulids (Annelida; Polychaeta). In Proceedings of the First International Polychaete Conference; Hutchings, P.A., Ed.; Linnean Society of New South West: Sydney, Australia, 1984; pp. 181-196.

42. Fitzhugh, K. A systematic revision of the Sabellidae-Caobangiidae-Sabellongidae complex (Annelida: Polychaeta). Bull. Am. Mus. Nat. Hist. 1989, 192, 1-104.

43. Kupriyanova, E.K. Life history evolution in serpulimorph polychaetes: A phylogenetic analysis. Hydrobiologia 2003, 496, 105-114. [CrossRef]

44. Macdonald, T.A. Phylogenetic relations among spirorbid subgenera and the evolution of opercular brooding. Hydrobiologia 2003, 496, 125-143. [CrossRef]

45. Kupriyanova, E.K.; Macdonald, T.A.; Rouse, G.W. Phylogenetic relationships within Serpulidae (Sabellida, Annelida) inferred from molecular and morphological data. Zool. Scr. 2006, 35, 421-439. [CrossRef]

46. Kupriyanova, E.K.; ten Hove, H.A.; Sket, B.; Zakšek, V.; Trontelj, P.; Rouse, G.W. Evolution of the unique freshwater cave-dwelling tube worm Marifugia cavatica (Annelida: Serpulidae). Syst. Biodivers 2009, 7, 389-401. [CrossRef]

47. Lehrke, J.; Harry, A.; Macdonald, T.A.; Bartolomaeus, T.; Bleidorn, C. Phylogenetic relationships of Serpulidae (Annelida: Polychaeta) based on $18 \mathrm{~S}$ rDNA sequence data, and implications for opercular evolution. Org. Divers Evol. 2007, 7, 195-206. [CrossRef]

48. Kupriyanova, E.K.; Nishi, E. Serpulidae (Annelida, Polychaeta) from Patton-Murray Seamounts, Gulf of Alaska, North Pacific Ocean. Zootaxa 2010, 2665, 51-68. [CrossRef]

49. Prentiss, N.K.; Vasileiadou, K.; Faulwetter, S.; Arvanitidis, C.; ten Hove, H.A. A new genus and species of Serpulidae (Annelida, Polychaeta, Sabellida) from the Caribbean Sea. Zootaxa 2014, 3900, 204-222. [CrossRef]

50. Rzhavsky, A.V.; Kupriyanova, E.K.; Sikorski, A.V. Two new species of serpulid polychaetes (Annelida) from the Barents Sea. Fauna Norv. 2013, 32, 27-38. [CrossRef]

51. Johansson, K.E. Beiträge Zur Kenntnis der Polychaeten-Familien Hermellidae Sabellidae und Serpulidae. Zool. Bidr. Uppsala 1927, $11,1-184$.

52. Fitzhugh, K. Further revisions of the Sabellidae subfamilies and cladistic relationships among the Fabriciinae (Annelida: Polychaeta). Zool. J. Linn. Soc. 1991, 102, 305-332. [CrossRef]

53. Fitzhugh, K. Systematics of several fabriciin fan worms (Polychaeta: Sabellidae: Fabriciinae) previously referred to Fabricia or Fabriciola. J. Nat. Hist. 1991, 25, 1101-1120. [CrossRef]

54. Fitzhugh, K. On the systematic position of Monroika africana (Monro) (Polychaeta: Sabellidae: Fabriciinae) and a description of a new fabriciin genus and species from Australia. Proc. Biol. Soc. Wash. 1992, 105, 116-131.

55. Fitzhugh, K. Additions to the description of the fanworm genus Pseudofabricia Cantone, 1972 (Polychaeta: Sabellidae: Fabriciinae). Contrib. Sci. 1995, 456, 1-6.

56. Fitzhugh, K. New fanworm species (Polychaeta: Sabellidae: Fabriciinae) in the genus Pseudofabriciola Fitzhugh. J. Nat. Hist. 1996, 30, 1267-1286. [CrossRef]

57. Fitzhugh, K. New fan worm genera and species (Polychaeta, Sabellidae, Fabriciinae) from the Western Pacific, and cladistic relationships among genera. Zool. Scr. 1998, 27, 209-245. [CrossRef]

58. Fitzhugh, K. New species of Fabricinuda Fitzhugh and Pseudofabriciola Fitzhugh (Polychaeta: Sabellidae: Fabriciinae), with an emendation of Pseudofabriciola australiensis (Hartmann-Schröder). J. Nat. Hist. 2002, 36, 893-925. [CrossRef]

59. Nogueira, J.M.D.M.; Fitzhugh, K.; Rossi, M.C.S. A new genus and new species of fan worms (Polychaeta: Sabellidae) from Atlantic and Pacific Oceans-the formal treatment of taxon names as explanatory hypotheses. Zootaxa 2010, 2603, 1-52. [CrossRef]

60. Fitzhugh, K.; Giangrande, A.; Simboura, N. New species of Pseudofabriciola Fitzhugh, 1990 (Polychaeta: Sabellidae: Fabriciinae), from the Mediterranean Sea. Zool. J. Linn. Soc. 1994, 110, 219-241. [CrossRef]

61. Fitzhugh, K. Fabricinuda, a new genus of Fabriciinae (Polychaeta: Sabellidae). Proc. Biol. Soc. Wash. 1990, 103, 161-178.

62. Fitzhugh, K. Two new genera of the Subfamily Fabriciinae (Polychaeta: Sabellidae). Am. Mus. Novit. 1990, $2967,1-19$.

63. Fitzhugh, K. A new deep-water genus and species of Fabriciinae fanworm (Polychaeta: Sabellidae) from Antarctica. Contrib. Sci. 2001, 491, 1-8.

64. Fitzhugh, K. A new species of Megalomma Johansson, 1927 (Polychaeta: Sabellidae: Sabellinae) from Taiwan, with comments on sabellid dorsal lip classification. Zool. Stud. 2003, 42, 106-134.

65. Rouse, G.; Fitzhugh, K. Broadcasting fables: Is external fertilization really primitive? sex, size, and larvae in sabellid polychaetes. Zool Scr. 1994, 23, 271-312. [CrossRef] 
66. Fitzhugh, K.; Rouse, G.W. A remarkable new genus and species of fan worm (Polychaeta: Sabellidae: Sabellinae) associated with marine gastropods. Invertebr. Biol. 1999, 118, 357-390. [CrossRef]

67. Cochrane, S. Snowflakes and feather-dusters-some challenges for soft-bottom fanworm systematics. Hydrobiologia 2003, 496, 49-62. [CrossRef]

68. Capa, M. Taxonomic revision and phylogenetic relationships of apomorphic sabellids (Polychaeta) from Australia. Invertebr. Syst. 2007, 21, 537. [CrossRef]

69. Capa, M. The genera Bispira Krøyer, 1856 and Stylomma Knight-Jones, 1997 (Polychaeta, Sabellidae): Systematic revision, relationships with close related taxa and new species from Australia. Hydrobiologia 2008, 596, 301-327. [CrossRef]

70. Capa, M.; Bybee, D.R.; Bybee, S.M. Establishing species and species boundaries in Sabellastarte Krøyer, 1856 (Annelida: Sabellidae): An integrative approach. Org. Divers. Evol. 2010, 10, 351-371. [CrossRef]

71. Tovar-Hernández, M.A. Phylogeny of Chone Krøyer, 1856 (Polychaeta: Sabellidae) and related genera. J. Nat. Hist. 2008, 42, 2193-2226. [CrossRef]

72. Capa, M.; Pons, J.; Hutchings, P. Cryptic diversity, intraspecific phenetic plasticity and recent geographical translocations in Branchiomma (Sabellidae, Annelida). Zool. Scr. 2013, 42, 637-655. [CrossRef]

73. Capa, M.; Murray, A. Integrative taxonomy of Parasabella and Sabellomma (Sabellidae: Annelida) from Australia: Description of new species, indication of cryptic diversity, and translocation of some species out of their natural distribution range: Australian Parasabella and Sabellomma. Zool. J. Linn. Soc. 2015, 175, 764-811. [CrossRef]

74. Capa, M.; Murray, A. Combined morphological and molecular data unveils relationships of Pseudobranchiomma (Sabellidae, Annelida) and reveals higher diversity of this intriguing group of fan worms in Australia, including potentially introduced species. ZooKeys 2016, 622, 1-36. [CrossRef]

75. Giangrande, A.; Licciano, M. The genus Euchone (Polychaeta, Sabellidae) in the Mediterranean Sea, addition of two new species and discussion on some closely related taxa. J. Nat. Hist. 2006, 40, 1301-1330. [CrossRef]

76. Licciano, M.; Giangrande, A.; Gambi, M.C. A new genus of Sabellidae (Annelida, Polychaeta) from Antarctica, with discussion of relationships among plesiomorphic genera within Sabellinae. Zootaxa 2009, 2226, 28-42. [CrossRef]

77. Kupriyanova, E.K.; Bastida-Zavala, R.; Halt, M.N.; Lee, M.S.Y.; Rouse, G.W. Phylogeny of the Serpula-Crucigera-Hydroides clade (Serpulidae: Annelida) using molecular and morphological data: Implications for operculum evolution. Invertebr. Syst. 2008, 22, 425-437. [CrossRef]

78. Sun, Y.; Kupriyanova, E.K.; Qiu, J.W. COI Barcoding of Hydroides: A road from impossible to difficult. Invertebr. Syst. 2012, 26, 539-547. [CrossRef]

79. Sun, Y.; Wong, E.; Ahyong, S.T.; Williamson, J.E.; Hutchings, P.A.; Kupriyanova, E.K. Barcoding and multi-locus phylogeography of the globally distributed calcareous tubeworm genus Hydroides Gunnerus, 1768 (Annelida, Polychaeta, Serpulidae). Mol. Phylogenet. Evol 2018, 127, 732-745. [CrossRef] [PubMed]

80. Tovar-Hernández, M.A.; Villalobos-Guerrero, T.F.; Kupriyanova, E.K.; Sun, Y. A new fouling Hydroides (Annelida, Sabellida, Serpulidae) from Southern Gulf of California. J. Mar. Biol. Assoc. UK 2016, 96, 693. [CrossRef]

81. Smith, A.M.; Henderson, Z.E.; Kennedy, M.; King, T.M.; Spencer, H.G. Reef formation versus solitariness in two New Zealand serpulids does not involve cryptic species. Aquat. Biol 2012, 16, 97-103. [CrossRef]

82. Willette, D.A.; Iniguez, A.R.; Kupriyanova, E.K.; Starger, C.J.; Varman, T.; Toha, A.H.; Maralit, B.A.; Barber, P.H. Christmas tree worms of Indo-Pacific coral reefs: Untangling the Spirobranchus corniculatus (Grube, 1862) complex. Coral Reefs 2015, 34, 899-904. [CrossRef]

83. Perry, O.; Bronstein, O.; Simon-Blecher, N.; Atkins, A.; Kupriyanova, E.; ten Hove, H.; Levy, O.; Fine, M. On the genus Spirobranchus (Annelida, Serpulidae) from the Northern Red Sea, and a description of a new species. Inverterb. Syst. 2018, 32, 605. [CrossRef]

84. Pazoki, S.; Rahimian, H.; Struck, T.H.; Katouzian, A.R.; Kupriyanova, E.K. A new species of the Spirobranchus kraussii-complex (Annelida, Serpulidae) from the Persian Gulf and Gulf of Oman. Zootaxa 2020, 4748, 401-430. [CrossRef] [PubMed]

85. Bailey, J.H. Methods of brood protection as a basis for reclassification of the Spirorbinae (Serpulidae). Zool. J. Linn. Soc. 1969, 48, 387-407. [CrossRef]

86. Thorp, C.H. The structure of the operculum in Pileolaria granulata (L.) (Polychaeta: Serpulidae) and related species. J. Exp. Mar. Biol. Ecol. 1975, 20, 215-235. [CrossRef]

87. Knight-Jones, P.; Thorp, C.H. The opercular brood chambers of Spirorbidae. J. Linn. Soc. (Zool.) 1984, 80, 121-133. [CrossRef]

88. Nishi, E. On the origin of brooding characteristics in spirorbids with the phylogeny of sabellids and serpulids (Annelida, Polychaeta, Sedentaria). Proc. Jap. Soc. Syst. Zool. 1993, 49, 6-12.

89. Thorp, C.; Segrove, F. The opercular moult in Spirorbis spirorbis (L.) and S. pusilloides Bush (Polychaeta: Serpulidae). J. Exp. Mar. Biol. Ecol. 1975, 19, 117-143. [CrossRef]

90. Rzhavsky, A.V.; Kupriyanova, E.K. Evolution of spirorbin brooding: A phylogenetic analysis and a test of an oxygen limitation hypothesis. Invertebr. Zool. 2019, 16, 409-430. [CrossRef]

91. Pamungkas, J.; Glasby, C.J.; Read, G.B.; Wilson, S.P.; Costello, M.J. Progress and perspectives in the discovery of polychaete worms (Annelida) of the world. Helgol. Mar. Res. 2019, 73, 4. [CrossRef]

92. Fitzhugh, K. A Revision of the genus Fabricia Blainville, 1828 (Polychaeta: Sabellidae: Fabriciinae). Sarsia 1990, 75, 1-16. [CrossRef] 
93. Cepeda, D.; Lattig, P. New reports and description of a new species of Sabellidae (Annelida) for the Iberian Peninsula and Balearic Archipelago. Mar. Biol. Res. 2017, 13, 832-853. [CrossRef]

94. Giangrande, A.; Wasson, B.; Lezzi, M.; Licciano, M. Description of Euchone anceps sp. nov. (Annelida: Sabellidae) from the Mediterranean Sea and Northeast Atlantic, with remarks on the difficulty of generic definition. Eur. Zool. J. 2017, 84, 193-207. [CrossRef]

95. Çinar, M.E.; Giangrande, A. A new species of Pseudobranchiomma (Sabellidae, Polychaeta) from the Sea of Marmara (Turkey). Mar. Biodivers 2018, 48, 1563-1569. [CrossRef]

96. López, E.; Olivier, F.; Grant, C.; Archambault, P.A. new species and four new records of sedentary polychaetes from the Canadian High Arctic. J. Mar. Biol. Assoc. UK 2017, 97, 1685-1694. [CrossRef]

97. Nishi, E.; Gil, J.; Tanaka, K.; Kupriyanova, E.K. Notaulax yamasui sp. n. (Annelida, Sabellidae) from Okinawa and Ogasawara, Japan, with notes on its ecology. ZooKeys 2017, 660,1-16. [CrossRef]

98. Nishi, E.; Tanaka, K.; Tovar-Hernández, M.A. A new species of Claviramus (Annelida, Sabellida, Sabellidae) from the Ariake Inland Sea, Kyushu, Japan. ZooKeys 2019, 880, 25-32. [CrossRef] [PubMed]

99. Tovar-Hernández, M.A.; de León-González, J.A.; Bybee, D.R. Sabellid worms from the Patagonian Shelf and Humboldt Current System (Annelida, Sabellidae): Phyllis Knight-Jones' and José María Orensanz's collections. Zootaxa 2017, 4283, 1-64. [CrossRef]

100. Tovar-Hernández, M.A.; Harry, A.; Vinn, O.; Zatoń, M.; de León-González, J.A.; García-Garza, M.E. Fan worms (Annelida: Sabellidae) from Indonesia collected by the Snellius II Expedition (1984) with descriptions of three new species and tube microstructure. PeerJ 2020, 8, e9692. [CrossRef]

101. Tovar-Hernández, M.A.; García-Garza, M.E.; de León-González, J.A. Sclerozoan and fouling sabellid worms (Annelida: Sabellidae) from Mexico with the establishment of two new species. Biodivers. Data J. 2020, 8, e57471. [CrossRef]

102. Bick, A.; Bastrop, R.; Kotta, J.; Meißner, K.; Meyer, M.; Syomin, V. Description of a new species of Sabellidae (Polychaeta, Annelida) from fresh and brackish waters in Europe, with some remarks on the branchial crown of Laonome. Zootaxa 2018, 4483, 349-364. [CrossRef]

103. Tilic, E.; Feerst, K.G.; Rouse, G.W. Two new species of Amphiglena (Sabellidae, Annelida), with an assessment of hidden diversity in the Mediterranean. Zootaxa 2019, 4648, 337-353. [CrossRef]

104. Renier, S.A. Osservazioni postume di Zoologia Adriatica, del Professore Stefano Andrea Renier, Membro Effettivo dell'Instituto Italiano, Pubblicate per Cura dell'IR Istituto Veneto Di Scienze, Lettere er Arti a Studio Del Membro Effettivo Prof. G. Meneghini. Giovanni Cecchini: Venice, Italia, 1847; pp. 1-122.

105. Linnaeus, C. Systema Naturae, 10th ed.; L. Salvius: Holmiae, Sweden, 1758.

106. Pillai, T.G. A revision of the genera Galeolaria and Pyrgopolon (Polychaeta: Serpulidae), with discussions on opercular insertion as a character in their taxonomy and relationships, and their zoogeography. Zootaxa 2009, 2060, 47-58. [CrossRef]

107. Kupriyanova, E.K.; Ippolitov, A.P. Deep-sea serpulids (Annelida: Polychaeta) in tetragonal tubes: On a tube convergence path from the Mesozoic to Recent. Zootaxa 2015, 4044, 151-200. [CrossRef]

108. Tovar-Hernández, M.A. Taxonomic update of the sabellids (Polychaeta: Sabellidae) from Chile and taxa established by prof. Ernst Ehlers, with a key to genera of Sabellinae. An. Inst. Patagon. 2010, 38, 7-29. [CrossRef]

109. Tovar-Hernández, M.A.; Fitzhugh, K. Sabellidae Latreille, 1825. In Poliquetos (Annelida: Polychaeta) de México y América Tropical, 2nd ed.; De León-González, J.A., Bastida-Zavala, J.R., Carrera-Parra, L.F., García-Garza, M.E., Salazar-Vallejo, S.I., Solís-Weiss, V., Tovar-Hernández, M.A., Eds.; Universidad Autónoma de Nuevo León: Monterrey, Mexico, 2021; Volume 3.

110. Ten Hove, H.A.; Kupriyanova, E.K. Taxonomy of Serpulidae (Annelida, Polychaeta): The state of affairs. Zootaxa 2009, 2036, 1-126. [CrossRef]

111. Knight-Jones, P.; Darbyshire, T.; Petersen, M.E.; Tovar-Hernández, M. What is Pseudopotamilla reniformis (Sabellidae)? Comparisons of populations from Britain, Iceland and Canada with comments on Eudistylia and Schizobranchia. Zootaxa 2017, 4254, 201-220. [CrossRef] [PubMed]

112. Jirkov, I. Polikhety Severnogo Ledovitogo Okeana [Polychaeta of the Arctic Ocean.]; Janus-K Press: Moscow, Russia, 2001 ; pp. 1-632. (In Russian)

113. Rzhavsky, A.V.; Kupriyanova, E.K.; Sikorski, A.V.; Dahle, S. Calcareous Tubeworms (Polychaeta, Serpulidae) of the Arctic Ocean; KMK Scientific Press: Moscow, Russia, 2014; pp. 1-187.

114. Rzhavsky, A.; Kupriyanova, E.; Sikorski, A. Field guide to Calcareous Tubeworms (Polychaeta, Serpulidae) of the Arctic Ocean; KMK Scientific Press: Moscow, Russia, 2018; pp. 1-184.

115. Fauvel, P. Polychètes sédentaires. Addenda aux errantes, Arachiannélides, Myzostomaires. In Faune de France; Paul Lechevalier: Paris, France, 1927; Volume 16, pp. 1-494.

116. Zibrowius, H. Étude morphologique, systématique et écologique des Serpulidae (Annelida Polychaeta) de La région de Marseille. Recl. Trav. Stn. Mar. Endoume Bull. 1968, 43, 81-252.

117. Bianchi, C.N. Les espèces de Serpuloidea (Annélides, Polychaètes) des lagunes côtières Italiennes. Rapp. Commis. Int. Mer. Médit. Monaco 1981, 27, 195-196.

118. Knight-Jones, P. Sabellidae and Serpulidae. In The Marine Fauna of the British Isles and North West Europe; Hayward, P.J., Ryland, J.S., Eds.; Clarendon Press: Oxford, UK, 1990; Volume 1, pp. 271-287.

119. López, E.; Cepeda, D. Familia Fabriciidae Rioja, 1923. In Fauna Ibérica; Museo Nacional de Ciencias Naturales, Consejo Superior de Investigaciones Científicas: Madrid, Spain, 2020. 
120. Cepeda, D.; López, E. Familia Sabellidae Latreille, 1825. In Fauna Ibérica; Museo Nacional de Ciencias Naturales, Consejo Superior de Investigaciones Científicas: Madrid, Spain, 2020.

121. Bick, A. Redescription of Fabriciola tonerella Banse, 1959, and a new record of Novafabricia infratorquata (Fitzhugh, 1983) from the Mediterranean Sea, with a key for the Fabriciinae (Annelida: Polychaeta) of the Mediterranean Sea and the North-East Atlantic. Zool. Anz. J. Comp. Zool. 2005, 244, 137-152. [CrossRef]

122. Bick, A.; Randel, N. Ontogenetic variations in characters of Euchone analis (Krøyer, 1856) (Polychaeta, Sabellidae, Sabellinae) from Spitsbergen, and new assignments of Oriopsis ingelorae Plate, 1995 and O. liefdefjordensis Plate, 1995. Acta Zool. 2005, 86, 145-157. [CrossRef]

123. Tovar-Hernández, M.A.; Licciano, M.; Giangrande, A. Revision of Chone Krøyer, 1856 (Polychaeta: Sabellidae) from the Eastern Central Atlantic and Mediterranean Sea with descriptions of two new species. Sci. Mar. 2007, 71, 315-338. [CrossRef]

124. Tovar-Hernández, M.A. Revision of Chone Krøyer, 1856 (Polychaeta: Sabellidae) from North America and descriptions of four new species. J. Nat. Hist. 2007, 41, 511-566. [CrossRef]

125. Çinar, M. Serpulid species (Polychaeta: Serpulidae) from the Levantine coast of Turkey (Eastern Mediterranean), with special emphasis on alien species. Aquat. Invasions 2006, 1, 223-240. [CrossRef]

126. Çinar, M.E. Alien polychaete species (Annelida: Polychaeta) on the Southern coast of Turkey (Levantine Sea, Eastern Mediterranean), with 13 new records for the Mediterranean Sea. J. Nat. Hist. 2009, 43, 2283-2328. [CrossRef]

127. Çinar, M.E.; Dağli, E.; Şahin, G.K. Checklist of Annelida from the coasts of Turkey. Turk. Zool. Derg. 2014, 38, 734-764. [CrossRef]

128. Selim, S.A.; Rzhavsky, A.V.; Britayev, T.A. Dialychone and Paradialychone (Polychaeta: Sabellidae) from the Mediterranean Coast of Egypt with description of Dialychone egyptica sp. n. Invertebr. Zool. 2012, 9, 105-114. [CrossRef]

129. Giangrande, A.; Cosentino, A.; Presti, C.L.; Licciano, M. Sabellidae (Annelida) from the Faro coastal lake (Messina, Ionian Sea), with the first record of the invasive species Branchiomma bairdi along the Italian Coast. Mediterr. Mar. Sci. 2012, 13, 283-293. [CrossRef]

130. Giangrande, A.; Caruso, L.; Mikac, B.; Licciano, M. The genus Megalomma (Annelida: Sabellidae) in the Mediterranean Sea, with description of two new species from Italian and Croatian Coasts. Ital. J. Zool. 2015, 82, 521-534. [CrossRef]

131. Mikac, B.A. Sea of worms: Polychaete checklist of the Adriatic Sea. Zootaxa 2015, 3943, 1-172. [CrossRef]

132. Mikac, B.; Licciano, M.; Jaklin, A.; Iveša, L.; Giangrande, A.; Musco, L. Diversity and distribution patterns of hard bottom polychaete assemblages in the North Adriatic Sea (Mediterranean). Diversity 2020, 12, 408. [CrossRef]

133. Mikac, B.; Giangrande, A.; Licciano, M. Sabellidae and Fabriciidae (Polychaeta) of the Adriatic Sea with particular retrospect to the Northern Adriatic and the description of two new species. J. Mar. Biol. Assoc. UK 2013, 93, 1511-1524. [CrossRef]

134. López, E.; Cepeda, D. Catálogo de las especies de Sabellidae Latreille, 1825 y Fabriciidae Rioja, 1923 (Annelida; Sabellida) citadas en la Península Ibérica e Islas Baleares y Chafarinas. Graellsia 2017, 73, e064. [CrossRef]

135. Kurt Şahin, G.; Çınar, M.E. A check-list of polychaete species (Annelida: Polychaeta) from the Black Sea. J. Black Sea/Medit. Environ. 2012, 18, 10-48.

136. Hartman, O. Atlas of the Sedentariate Polychaetous Annelids from California; Allan Hancock Foundation, University of Southern California: Los Angeles, CA, USA, 1969; pp. 1-812.

137. Knight-Jones, P.; Knight-Jones, E.W.; Dales, R.P. Spirorbidae (Polychaeta Sedentaria) from Alaska to Panama. J. Zool. 1979, 189, 419-458. [CrossRef]

138. Buzhinskaja, G. Polychaetes of the Far East. Seas of Russia and Adjacent Waters of the Pacific Ocean.: Annotated Checklist and Bibliography; KMK Scientific Press: Moscow, Russia, 2013; pp. 1-131.

139. Nishi, E.; Tanaka, K.; Tovar-Hernández, M.A.; Giangrande, A. Dialychone, Jasmineira and Paradialychone (Annelida: Polychaeta: Sabellidae) from Japan and adjacent waters, including four new species descriptions. Zootaxa 2009, 2167, 1-24. [CrossRef]

140. Yoshihara, T.; Hiruta, S.; Katoh, T.; Kajihara, H. Three species of Amphicorina (Annelida, Sabellida, Sabellidae) from Japan, with descriptions of two new species. Zookeys 2012, 187, 45-62. [CrossRef]

141. Imajima, M. Kankeidoubutsu Tamourui (Annelida Polychaeta); Biological Research Co.: Tokyo, Japan, 1996; pp. 1-530. (In Japanese)

142. Sun, R.; Yang, D. Polychaeta III. Sabellida. In Fauna Sinica: Invertebrata; Science Press: Beijing, China, 2014.

143. Glasby, C.J.; Lee, Y.-L.; Hsueh, P.-W. Marine Annelida (excluding clitellates and siboglinids) from the South China Sea. Raffles Bull. Zool. 2016, 34, 178-234.

144. Bastida-Zavala, J.R.; ten Hove, H.A. Revision of Hydroides Gunnerus, 1768 (Polychaeta: Serpulidae) from the Eastern Pacific Region and Hawaii. Beaufortia 2003, 53, 67-110.

145. Bastida-Zavala, J.R. Serpulids (Annelida: Polychaeta) from the Eastern Pacific, including a brief mention of Hawaiian serpulids. Zootaxa 2008, 1722, 1-61.

146. Bastida-Zavala, J.R.; McCann, L.D.; Keppel, E.; Ruiz, G.M. The fouling serpulids (Polychaeta: Serpulidae) from United States coastal waters: An overview. Eur. J. Taxon. 2017, 344, 1-76. [CrossRef]

147. Tovar-Hernández, M.A.; Méndez, N.; Villalobos-Guerrero, T.F. Fouling polychaete worms from the Southern Gulf of California: Sabellidae and Serpulidae. Syst. Biodivers 2009, 7, 319-336. [CrossRef]

148. Bastida-Zavala, J.R.; Buelna, A.S.R.; De León-González, J.A.; Camacho-Cruz, K.A.; Carmona, I. New records of sabellids and serpulids (Polychaeta: Sabellidae, Serpulidae) from the Tropical Eastern Pacific. Zootaxa 2016, 4184, 401-457. [CrossRef]

149. Tovar-Hernández, M.A.; Carrera-Parra, L.F. Megalomma Johansson, 1925 (Polychaeta: Sabellidae) from America and other world-wide localities, and phylogenetic relationships within the genus. Zootaxa 2011, 2861, 1-71. [CrossRef] 
150. Zibrowius, H. Contribution a l'etude des Serpulidae (Polychaeta Sedentaria) du Bresil. Bol. Inst. Oceanogr. 1970, 19, 1-32. [CrossRef]

151. Ten Hove, H.A. Serpulinae (Polychaeta) from the Caribbean: I-the genus Spirobranchus. Stud. Fauna Curaçao 1970, $32,1-57$.

152. Ten Hove, H.A. Serpulinae (Polychaeta) from the Caribbean: II-the genus Sclerostyla. Stud. Fauna Curaçao 1973, $43,1-21$.

153. ten Hove, H.A. Serpulinae (Polychaeta) from the Caribbean: III-the genus Pseudovermilia. Stud. Fauna Curaçao 1975, 47, 46-101.

154. Ten Hove, H.A. Serpulinae (Polychaeta) from the Caribbean: IV Pseudovermilia madracicola sp. n., a symbiont of corals. In Natuurwetenschappelijke Studiekring voor Suriname en de Nederlandse Antillen; Van Der Steen, L.J., Ed.; 1989; Volume 123, pp. 135-144.

155. Giangrande, A.; Licciano, M.; Gambi, M.C. A collection of Sabellidae (Polychaeta) from Carrie Bow Cay (Belize, Western Caribbean Sea) with the description of two new species. Zootaxa 2007, 1650, 41-53. [CrossRef]

156. Tovar-Hernández, M.A. Redescription of Chone americana Day, 1973 (Polychaeta: Sabellidae) and description of five new species from the Grand Caribbean Region. Zootaxa 2005, 1070, 1-30. [CrossRef]

157. Tovar-Hernández, M.A.; Knight-Jones, P. Species of Branchiomma (Polychaeta: Sabellidae) from the Caribbean Sea and Pacific Coast of Panama. Zootaxa 2006, 1189, 1-37. [CrossRef]

158. Tovar-Hernández, M.A.; Salazar-Vallejo, S.I. Sabellids (Polychaeta: Sabellidae) from the Grand Caribbean. Zool. Stud. 2006, 45, 24-66.

159. Bastida-Zavala, J.R.; ten Hove, H.A. Revision of Hydroides Gunnerus, 1768 (Polychaeta: Serpulidae) from the Western Atlantic Region. Beaufortia 2002, 52, 103-173.

160. Bastida-Zavala, R. Serpula and Spiraserpula (Polychaeta, Serpulidae) from the Tropical Western Atlantic and Gulf of Guinea. ZooKeys 2012, 198, 1-23. [CrossRef] [PubMed]

161. Nogueira, J.; Knight-Jones, P.A. New species of Pseudobranchiomma Jones (Polychaeta: Sabellidae) found amongst Brazilian coral, with a redescription of P. punctata (Treadwell, 1906) from Hawaii. J. Nat. Hist. 2002, 36, 1661-1670. [CrossRef]

162. Nogueira, J.M.D.M.; Abbud, A. Three new serpulids (Polychaeta: Serpulidae) from the Brazilian Exclusive Economic Zone. Zoosymposia 2009, 2, 201-227. [CrossRef]

163. Amaral, A.C.Z.; Nallin, S.A.H.; Steiner, T.M.; Forroni, T.D.O.; Gomes-Filho, D. Catálogo das Espécies de Annelida Polychaeta do Brasil; Unicamp: Campinas, Brazil, 2013; pp. 1-159.

164. Costa, D. de A.; Fernandes, H.F.; da Silva, F. de A.; Christoffersen, M.L. Checklist de espécies de Polychaeta (Annelida) da Praia do Seixas, João Pessoa, Estado Da Paraíba, Nordeste do Brasil. Rev. Bras. Gestão Amb. Sust. 2017, 4, 313-320. [CrossRef]

165. Bastida-Zavala, J.R.; Sánchez Ovando, J.P. Serpulidae Rafinesque 1815. In Poliquetos (Annelida: Polychaeta) de México y América Tropical, 2nd ed.; De León-González, J.A., Bastida-Zavala, J.R., Carrera-Parra, L.F., García-Garza, M.E., Salazar-Vallejo, S.I., Solís-Weiss, V., Tovar-Hernández, M.A., Eds.; Universidad Autónoma de Nuevo León: Monterrey, Mexico, 2021 ; Volume 3.

166. Fauvel, P. Annelida Polychaeta. In Fauna of India, Pakistan, Ceylon, Burma and Malaya; The Indian Press Ltd: Allahabad, India, 1953; pp. 1-507.

167. Sivadas, S.K.; Carvalho, R. Marine Annelida of India: Taxonomy and status evaluation and an updated checklist. J. Threat. Taxa 2020, 12, 16647-16714.

168. Pillai, G. Some marine and brackish-water serpulid polychaetes from Ceylon, including new genera and species. Ceylon J. Sci. (Biol. Sci.) 1960, 3, 1-40.

169. Pillai, T.G. Annelida Polychaeta of Tambalagam Lake, Ceylon. Ceylon J. Sci. (Biol. Sci.) 1961, 4, 1-40.

170. Wehe, T.; Fiege, D. Annotated checklist of the polychaete species of the seas surrounding the Arabian Peninsula: Red Sea, Gulf of Aden, Arabian Sea, Gulf of Oman, Arabian Gulf. Fauna Arabia 2002, 19, 7-238.

171. Al-Kandari, M.; Sattari, Z.; Hussain, S.; Radashevsky, V.I.; Zhadan, A. Checklist of intertidal Polychaetes (Annelida) of Kuwait, Northern Part of the Arabian Gulf. Reg. Stud. Mar. Sci. 2019, 32, 100872. [CrossRef]

172. Ben-Eliahu, M.N.; ten Hove, H.A. Serpulidae (Annelida: Polychaeta) from the Suez Canal-from a Lessepsian migration perspective (a monograph). Zootaxa 2011, 2848, 1-147. [CrossRef]

173. Knight-Jones, E.W.; Knight-Jones, P.; Oliver, P.G.; Mackie, A.S.Y. A.S.Y. A new species of Hyalopomatus (Serpulidae: Polychaeta) which lacks an operculum: Is this an adaptation to low oxygen. In Interactions and Adaptation Strategies of Marine Organisms; Naumov, A.D., Hummel, H., Sukhotin, A.A., Ryland, J.S., Eds.; Springer: Dordrecht, The Netherlands, $1997 ;$ pp. 145-151.

174. Veron, J.E.; Devantier, L.M.; Turak, E.; Green, A.L.; Kininmonth, S.; Stafford-Smith, M.; Peterson, N. Delineating the Coral Triangle. Galaxea 2009, 11, 91-100. [CrossRef]

175. Fitzhugh, K. Fan worm polychaetes (Sabellidae: Sabellinae) collected during the Thai-Danish BIOSHELF Project. Phuket Mar. Biol. Center Spec. Publ. 2002, 24, 353-424.

176. Al-Hakim, I.; Glasby, C.J. Polychaeta (Annelida) of the Natuna Islands, South China Sea. Raffles Bull. Zool. 2004, $21,25-45$.

177. Sun, Y.; ten Hove, H.A.; Qiu, J.W. Serpulidae (Annelida: Polychaeta) from Hong Kong. Zootaxa 2012, 3424, 1-42. [CrossRef]

178. Murray, A.; Rouse, G.W. Two new species of Terebrasabella (Annelida: Sabellidae: Sabellinae) from Australia. Zootaxa 2007, 1434, 51-68. [CrossRef]

179. Kupriyanova, E.K.; Sun, Y.; ten Hove, H.A.; Wong, E.; Rouse, G.W. Serpulidae (Annelida) of Lizard Island, Great Barrier Reef, Australia. Zootaxa 2015, 4019, 275-353. [CrossRef]

180. Sun, Y.; Wong, E.; ten Hove, H.A.; Hutchings, P.A.; Williamson, J.E.; Kupriyanova, E.K. Revision of the genus Hydroides (Annelida: Serpulidae) from Australia. Zootaxa 2015, 4009, 1-99. [CrossRef] [PubMed] 
181. Wilson, R.S.; Hutchings, P.A.; Glasby, C.J. Polychaetes: An. Interactive Identification Guide; CSIRO Publishing: Collingwood, VIC, Australia, 2003; pp. 1-24.

182. Kupriyanova, E.K.; Wong, E.; Hutchings, P.A. Invasive Polychaete Identifier-an Australian Perspective. Version 1.12013. Available online: http:/ / polychaetes.australianmuseum.net.au/ (accessed on 3 March 2021).

183. Kupriyanova, E.; Hutchings, P.; Wong, E. A fully illustrated web-based guide to distinguish native and introduced polychaetes of Australia. Manag. Biol. Invasions 2016, 7, 305-312. [CrossRef]

184. Bailey-Brock, J.H.; Magalhães, W.F. A new species and record of Serpulidae (Annelida: Polychaeta) from Cross Seamount in the Hawaiian Chain. Zootaxa 2012, 3192, 49-58. [CrossRef]

185. Keppel, E.; Tovar-Hernández, M.A.; Ruiz, G. New records of the non-indigenous species Branchiomma bairdi and B. conspersum (Polychaeta: Sabellidae) on the Pacific Coast of North America. Bioinvasions Rec. 2018, 7, 229-236. [CrossRef]

186. Bailey-Brock, J.H.; Magalhães, W.F.; Brock, R.E. Coral reef inhabiting tubeworms (Polychaeta: Serpulidae) from Enewetak, Kwajalein, Rongelap and Utirik Atolls, Marshall Islands. J. Mar. Biol. Assoc. UK 2012, 92, 967-988. [CrossRef]

187. Capa, M.; López, E. Sabellidae (Annelida: Polychaeta) living in blocks of dead coral in the Coiba National Park, Panama. J. Mar. Biol. Assoc. UK 2004, 84, 63-72. [CrossRef]

188. Yáñez-Rivera, B.; Tovar-Hernández, M.A.; Galván-Villa, C.M.; Ríos-Jara, E. Tubicolous polychaete worms (Annelida) from Bahía de Chamela Islands Sanctuary, Mexico, with the description of a new bamboo worm. Biodivers. Data J. 2020, 8, e57572. [CrossRef]

189. Keppel, E.; Keith, I.; Ruiz, G.M.; Carlton, J.T. New records of native and non-indigenous Polychaetes (Annelida: Polychaeta) in the Galapagos Islands. Aquat. Invasions 2019, 14, 59-84. [CrossRef]

190. Elías, R.; Jaubet, M.L.; Ferrando, A.; Saracho, M. Historia y perspectivas de los estudios sobre poliquetos en Argentina. In Poliquetos de Sudamérica; Díaz-Díaz, O., Bone, D., Rodríguez, C.T., Delgado-Blas, V.H., Eds.; Poliquetos de Sudamérica. Volumen especial del Boletín del Instituto Oceanográfico de Venezuela: Cumaná, Venezuela, 2017; pp. 3-23.

191. Rozbaczylo, O.; Moreno, R.A.; Díaz-Díaz, Ó. Poliquetos Bentónicos en Chile. In Poliquetos de Sudamérica; Díaz-Díaz, Ó., Bone, D., Rodríguez, C.T., Delgado-Blas, V.H., Eds.; Volumen especial del Boletín del Instituto Oceanográfico de Venezuela: Cumaná, Venezuela, 2017; pp. 51-70.

192. Kupriyanova, E.K.; ten Hove, H.A.; Nishi, E.A. Taxonomic revision of Pseudochitinopoma Zibrowius, 1969 (Annelida, Serpulidae) with description of two new species. Zootaxa 2012, 3507, 57-78. [CrossRef]

193. Simon, C.A.; van Niekerk, H.H.; Burghardt, I.; ten Hove, H.A.; Kupriyanova, E.K. Not out of Africa: Spirobranchus kraussii (Baird, 1865) is not a global fouling and invasive serpulid of Indo-Pacific Origin. Aquat. Invasions 2019, 14, 221-249. [CrossRef]

194. Day, J.H. A Monograph on the Polychaeta of Southern Africa. Part II. Brit. Mus. Nat. Hist. Publ. 1967, 656, 459-878.

195. Knight-Jones, P. New species and a new subgenus of Spirorbinae (Serpulidae: Polychaeta) from Kenya. J. Zool. 1972, 166, 1-18. [CrossRef]

196. Knight-Jones, P.; Knight-Jones, E.W. Spirorbinae (Polychaeta: Serpulidae) from South Africa, including three new species. Mar. Biol. 1974, 25, 253-261. [CrossRef]

197. Knight-Jones, E.W.; Knight-Jones, P.; Llewellyn, L.C. Spirorbinae (Polychaeta: Serpulidae) from Southeastern Australia. Notes on their taxonomy, ecology and distribution. Rec. Aust. Mus. 1974, 29, 107-151. [CrossRef]

198. Vine, P.J. The marine fauna of New Zealand. Spirorbinae (Polychaeta: Serpulidae). NZOI Mem. 1977, 68, 1-66.

199. Glasby, C.J.; Read, G.B. A chronological review of polychaete taxonomy in New Zealand. J. R. Soc. N. Z. 1998, $28,347-374$. [CrossRef]

200. Capa, M.; Rouse, G.W. Phylogenetic relationships within Amphiglena Claparède, 1864 (Polychaeta: Sabellidae), description of five new species from Australia, a new species from Japan, and comments on previously described species. J. Nat. Hist. 2007, 41, 327-356. [CrossRef]

201. Capa, M.; Murray, A. Review of the genus Megalomma (Polychaeta: Sabellidae) in Australia with description of three new species, new records and notes on certain features with phylogenetic implications. Rec. Aust. Mus. 2009, 61, 201-224. [CrossRef]

202. Murray, A.; Keable, S.J. First report of Sabella spallanzanii (Gmelin, 1791) (Annelida: Polychaeta) from Botany Bay, New South Wales, a northern range extension for the invasive species within Australia. Zootaxa 2013, 3670, 391-395. [CrossRef]

203. Sun, Y.; Wong, E.; Tovar-Hernández, M.A.; Williamson, J.E.; Kupriyanova, E.K. Is Hydroides brachyacantha (Serpulidae: Annelida) a widespread species? Invertebr. Syst. 2016, 30, 41-59. [CrossRef]

204. Styan, C.; McCluskey, C.; Sun, Y.; Kupriyanova, E. Cryptic sympatric species across the Australian range of the global estuarine invader Ficopomatus enigmaticus (Fauvel, 1923) (Serpulidae, Annelida). Aquat. Invasions 2017, 12, 53-65. [CrossRef]

205. Baird, W. Description of a new species of annelids belonging to the Family Amphinomidae. Trans. Linn. Soc. London 1864, 24, 449-450. [CrossRef]

206. Baird, W. Description of several new species and varieties of tubicolous annelids (= Tribe Limivora of Grube), in the collection of the British Museum. J. Linn. Soc. Zool. 1865, 8, 10-22. [CrossRef]

207. Ehlers, E. Polychaeten der Hamburger Magalhaenischen Sammelreise. Ergeb. Hambg. Magalhaenischen Sammelreise Liefersung 1897, 2, 1-147.

208. Gravier, C. Sur les Annélides Polychètes Recueillies par l’Expédition Antarctique Française (Terebelliens, Serpuliens). Bull. Mus. d'Hist. Nat. Paris 1907, 13, 46-52.

209. Pixell, H.L.M. Polychaeta of the Families Serpulidae and Sabellidae, collected by the Scottish National Antarctic Expedition. Trans. R. Soc. Edinburgh 1913, 49, 347-358. [CrossRef] 
210. Benham, W.B. Polychaeta. British Antarctic "Terra Nova" Expedition, 1910. Nat. Hist. Rep. Zool. 1927, 7, 47-182.

211. Rzhavsky, A.V. Two new species of Pileolaria (Polychaeta: Spirorbidae) from the Southern hemisphere with a brief review of related species. Inverterb. Zool. 2010, 7, 81-91. [CrossRef]

212. Tovar-Hernández, M.A.; Yáñez-Rivera, B.; Giangrande, A.; Gambi, M.C. Notes on the species of Perkinsiana (Polychaeta: Sabellidae) from Antarctica with the description of P. brigittae sp. nov. Zootaxa 2012, 3485, 56-68. [CrossRef]

213. Neal, L.; Paterson, G.L.; Blockley, D.; Scott, B.; Sherlock, E.; Huque, C.; Glover, A.G. Biodiversity data and new species descriptions of polychaetes from offshore waters of the Falkland Islands, an area undergoing hydrocarbon exploration. ZooKeys 2020, 938, 1-86. [CrossRef]

214. Kupriyanova, E.K.; Rzhavsky, A.; ten Hove, H.A. Serpulidae Rafinesque, 1815. In Handbook of Zoology, Annelida, Volume 2: Pleistoannelida, Sedentaria II; Purschke, G., Böggemann, M., Westheide, W., Eds.; De Gruyter: Berlin, Germany, 2019; pp. 213-275.

215. Jones, M.L. Brandtika asiatica new genus, new species, from Southeastern Asia and a redescription of Monroika africana (Monro) (Polychaeta: Sabellidae). Proc. Biol. Soc. Wash. 1974, 87, 217-230.

216. Atkinson, S.D.; Bartholomew, J.L.; Rouse, G.W. The invertebrate host of salmonid fish parasites Ceratonova shasta and Parvicapsula minibicornis (Cnidaria: Myxozoa), is a novel fabriciid annelid, Manayunkia occidentalis sp. nov. (Sabellida: Fabriciidae). Zootaxa 2020, 4751, 310-320. [CrossRef]

217. Sitnikova, T.Y.; Shcherbakov, D.Y.; Kharchenko, V.V. On taxonomic status of polychaetes of the genus Manayunkia (Sabellidae, Fabriciinae) from the open Lake Baikal. Zool. Zhurnal 1997, 76, 16-27.

218. Monro, C.C.A. On a collection of Polychaeta from near the Mouth of the River Congo. Rev. Zool. Bot. Afr. 1939, $32,213-225$.

219. Rouse, G. New Fabriciola and Manayunkia species (Fabriciinae: Sabellidae: Polychaeta) from Papua New Guinea. J. Nat. Hist. 1996, 30, 1761-1778. [CrossRef]

220. Baumhaker, H. Taxonomische Untersuchungen an Sabellidae und Fabriciidae (Annelida: Polychaeta) der Tiefsee des SüdwestAtlantiks. Master's Thesis, University of Rostock, Rostock, Germany, 2012.

221. Bok, M.J.; Capa, M.; Nilsson, D.-E. Here, there and everywhere: The radiolar eyes of fan worms (Annelida, Sabellidae). Integr. Comp. Biol. 2016, 56, 784-795. [CrossRef]

222. Brown, S.D.; Emlet, R.B. Natural radiole damage and regeneration in the feather duster worm Schizobranchia insignis. Invertebr. Biol. 2020, e12307. [CrossRef]

223. Orrhage, L. On the structure and homologues of the anterior end of the polychaete families Sabellidae and Serpulidae. Zoomorphology 1980, 96, 113-167. [CrossRef]

224. Giangrande, A. The genus Chone (Polychaeta, Sabellidae) in the Mediterranean Sea with description of C. longiseta n. sp. Boll. Zool. 1992, 59, 517-529. [CrossRef]

225. Tovar-Hernández, M.A.; Sosa-Rodríguez, T. Redescription of Chone infundibuliformis Krøyer, 1856 (Polychaeta: Sabellidae) and histology of the branchial crown appendages, collar and glandular ridge. Zootaxa 2006, 1115, 31-59. [CrossRef]

226. Capa, M.; Nogueira, J.M.D.M.; Rossi, M.C.S. Comparative internal structure of dorsal lips and radiolar appendages in Sabellidae (Polychaeta) and phylogenetic implications. J. Morphol. 2011, 272, 302-319. [CrossRef] [PubMed]

227. Ippolitov, A.P.; Vinn, O.; Kupriyanova, E.K.; Jäger, M. Written in stone: History of serpulid polychaetes through time. Mem. Mus. Vic. 2014, 71, 123-160. [CrossRef]

228. Wong, E.; Kupriyanova, E.K.; Hutchings, P.; Capa, M.; Radashevsky, V.I.; ten Hove, H.A. A graphically illustrated glossary of polychaete terminology: Invasive species of Sabellidae, Serpulidae and Spionidae. Mem. Mus. Vic. 2014, 71, 327-342. [CrossRef]

229. Handley, S.J. Spionid polychaetes in Pacific oysters, Crassostrea gigas (Thunberg) from Admiralty Bay, Marlborough Sounds, New Zealand. N. Z. J. Mar. Freshw. Res. 1995, 29, 305-309. [CrossRef]

230. Bick, A. Morphology and ecology of Dipolydora armata (Polychaeta, Spionidae) from the Western Mediterranean Sea. Acta Zool. 2001, 11, 177-187. [CrossRef]

231. Bick, A. Polychaete communities associated with gastropod shells inhabited by the hermit crabs Clibanarius erythropus and Calcinus tubularis from Ibiza, Mediterranean Sea. J. Mar. Biol. Assoc. UK 2006, 86, 83-92. [CrossRef]

232. Rouse, G.W.; Pleijel, F. Polychaetes; Oxford University Press: London, UK, 2001; pp. 1-354.

233. Bick, A. Bedeutung Postlarvaler Ontogenetischer Merkmalsvariationen für die Taxonomie der Spionidae und Sabellidae; Habilitationsschrift an der Mathematisch-Naturwissenschaftliche Fakultät Fakultät der Universität Rostock: Rostock, Germany, 2007.

234. Costa-Paiva, E.M.; Paiva, P.C. Anaesthetization and fixation effects on the morphology of sabellid polychaetes (Annelida: Polychaeta: Sabellidae). J. Mar. Biol. Assoc. UK 2007, 87, 1127-1132. [CrossRef]

235. Coleman, C.O. "Digital inking": How to make perfect line drawings on computers. Org. Div. Evol. Electr. Suppl. 2003, 14, 1-14. [CrossRef]

236. Paterson, G.L.; Sykes, D.; Faulwetter, S.; Merk, R.; Ahmed, F.; Hawkins, L.E.; Dinley, J.; Ball, A.D.; Arvanitidis, C. The pros and cons of using micro-computed tomography in gross and micro-anatomical assessments of polychaetous annelids. Mem. Mus. Vic. 2014, 71, 237-246. [CrossRef]

237. Parapar, J.; Candás, M.; Cunha-Veira, X.; Moreira, J. Exploring annelid anatomy using micro-computed tomography: A taxonomic approach. Zool. Anz. 2017, 270, 19-42. [CrossRef]

238. Patti, F.P.; Gambi, M.C.; Giangrande, A. Preliminary study on the systematic relationships of Sabellinae (Polychaeta, Sabellidae), based on the $\mathrm{C} 1$ domain of the $28 \mathrm{~S}$ rDNA, with discussion of reproductive features. Ital. J. Zool. 2003, 70, 269-278. [CrossRef]

239. Halanych, K.M. A review of molecular markers used for annelid phylogenetics. Integr. Comp. Biol. 2006, 46, 533-543. [CrossRef] 
240. Carr, C.M.; Hardy, S.M.; Brown, T.M.; Macdonald, T.A.; Hebert, P.D.N. A Tri-Oceanic perspective: DNA barcoding reveals geographic structure and cryptic diversity in Canadian polychaetes. PLoS ONE 2011, 6, e22232. [CrossRef] [PubMed]

241. Seixas, V.C.; de Moraes Russo, C.A.; Paiva, P.C. Mitochondrial genome of the Christmas Tree Worm Spirobranchus giganteus (Annelida: Serpulidae) reveals a high substitution rate among annelids. Gene 2017, 605, 43-53. [CrossRef]

242. Sun, Y.; Daffe, G.; Zhang, Y.; Qiu, J.-W.; Kupriyanova, E.K. Another blow to the conserved gene order in Annelida: Mitogenomics reveals extensive gene rearrangement in the tubeworm genus Hydroides (Serpulidae). Mol. Phylogenet. Evol. 2021, 107124. [CrossRef] [PubMed]

243. Tilic, E.; Atkinson, S.D.; Rouse, G.W. Mitochondrial genome of the freshwater annelid Manayunkia occidentalis (Sabellida: Fabriciidae). Mitochondrial DNA B 2020, 5, 3313-3315. [CrossRef] [PubMed]

244. Daffe, G.; Sun, Y.; Ahyong, S.T.; Kupriyanova, E.K. Mitochondrial genome of Sabella spallanzanii (Sabellida: Sabellidae). Mitochondrial DNA B 2020, 6, 499-501. [CrossRef] [PubMed]

245. Takahashi, T.; McDougall, C.; Troscianko, J.; Chen, W.-C.; Jayaraman-Nagarajan, A.; Shimeld, S.M.; Ferrier, D.E. An EST screen from the annelid Pomatoceros lamarckii reveals patterns of gene loss and gain in animals. BMC Evol. Biol. 2009, 9, 1-17. [CrossRef]

246. De Queiroz, K. Species concepts and species delimitation. Syst. Biol. 2007, 56, 879-886. [CrossRef]

247. Barraclough, T.G. Evolving entities: Towards a unified framework for understanding diversity at the species and higher levels. Phil. Trans. R. Soc. B Biol. Sci. 2010, 365, 1801-1813. [CrossRef] [PubMed]

248. Nygren, A. Cryptic polychaete diversity: A review. Zool. Scr. 2014, 43, 172-183. [CrossRef]

249. Halt, M.N.; Kupriyanova, E.K.; Cooper, S.J.B.; Rouse, G.W. Naming species with no morphological indicators: Species status of Galeolaria caespitosa (Annelida: Serpulidae) inferred from nuclear and mitochondrial gene sequences and morphology. Invertebr. Syst. 2009, 23, 205-222. [CrossRef]

250. Sun, Y.; Wong, E.; Keppel, E.; Williamson, J.E.; Kupriyanova, E.K. A global invader or a complex of regionally distributed species? clarifying the status of an invasive calcareous tubeworm Hydroides dianthus (Verrill, 1873) (Polychaeta: Serpulidae) Using DNA Barcoding. Mar. Biol. 2017, 164, 28-1-28-12. [CrossRef]

251. Sun, Y.; Al-Kandari, M.; Kubal, P.; Walmiki, N.; Kupriyanova, E.K. Cutting a Gordian knot of tubeworms with DNA data: The story of the Hydroides operculata-complex (Annelida, Serpulidae). Zootaxa 2017, 4323, 39-48. [CrossRef]

252. Palero, F.; Torrado, H.; Perry, O.; Kupriyanova, E.K.; Ulman, A.; Genis-Armero, R.; ten Hove, H.A.; Capaccioni-Azzati, R. Following the Phoenician example: Western Mediterranean colonization by Spirobranchus cf. tetraceros (Annelida: Serpulidae). Sci. Mar. 2020, 84, 83-92. [CrossRef]

253. Hebert, P.D.; Ratnasingham, S.; De Waard, J.R. Barcoding animal life: Cytochrome c oxidase subunit 1 divergences among closely related species. Proc. R. Soc. London Biol. Sci. 2003, 270, S96-S99. [CrossRef]

254. Rech, S.; Borrell Pichs, Y.J.; García-Vazquez, E. Anthropogenic marine litter composition in coastal areas may be a predictor of potentially invasive rafting fauna. PLOS ONE 2018, 13, e0191859. [CrossRef] [PubMed]

255. Langeneck, J.; Lezzi, M.; Del Pasqua, M.; Musco, L.; Gambi, M.C.; Castelli, A.; Giangrande, A. Non-indigenous polychaetes along the coasts of Italy: A critical review. Mediterr. Mar. Sci. 2020, 21, 238-275. [CrossRef]

256. Rech, S.; Salmina, S.; Pichs, Y.J.B.; García-Vazquez, E. Dispersal of alien invasive species on anthropogenic litter from European mariculture areas. Mar. Poll. Bull. 2018, 131, 10-16. [CrossRef]

257. Hutchings, P.; De Decker, P.; Geddes, M.C. A new species of Manayunkia (Polychaeta) from ephemeral lakes near the Coorong, South Australia. Trans. R. Soc. S. Aust. 1981, 105, 25-28.

258. Schütz, L. Über Verbreitung, Ökologie und Biologie des Brackwasserpolychaeten Manayunkia aestuarina (Bourne) Insbesondere an den Küsten Schleswig-Holsteins. Faun. Mitt. Norddeut. 1965, 9, 226-234.

259. Lewis, D.B. Some aspects of the ecology of Fabricia sabella (Ehr.) (Annelida, Polychaeta). J. Linn. Soc. (Zool.) 1968, 47, 515-526. [CrossRef]

260. Light, W.J. Extension of range for Manayunkia aestuarina (Polychaeta: Sabellidae) to British Columbia. J. Fish. Board Canada 1969, 26, 3088-3091. [CrossRef]

261. Bagheri, E.; McLusky, D. Population dynamics of oligochaetes and small polychaetes in the polluted forth estuary ecosystem. Neth. J. Sea Res. 1982, 16, 55-66. [CrossRef]

262. Bick, A. Reproduction and larval development of Manayunkia aestuarina (Bourne, 1883) (Polychaeta, Sabellidae) in a coastal region of the Southern Baltic. Helgoländer Meeresunters 1996, 50, 287-298. [CrossRef]

263. Giangrande, A.; Gambi, M.; Micheli, F.; Kroeker, K. Fabriciidae (Annelida, Sabellida) from a naturally acidified coastal system (Italy) with description of two new species. J. Mar. Biol. Assoc. UK 2014, 94, 1417. [CrossRef]

264. Muus, B.J. The Fauna of Danish estuaries and lagoons: Distribution and ecology of dominating species in the shallow reaches of the mesohaline zone. Medd. Danmarks Fisk. Havunders (n. ser.) 1967, 5, 1-316.

265. Lewis, D.B. Feeding and tube-building in the Fabriciinae (Annelida, Polychaeta). Proc. Linn. Soc. Lond. 1968, 179, 37-49. [CrossRef]

266. Hartman, O. Fabricinae (Featherduster Polychaetous Annelids) in the Pacific. Pac. Sci. 1951, 5, 379-391.

267. Bartholomew, J.L.; Atkinson, S.D.; Hallett, S.L. Involvement of Manayunkia speciosa (Annelida: Polychaeta: Sabellidae) in the life cycle of Parvicapsula minibicornis, a myxozoan parasite of Pacific salmon. J. Parasitol. 2006, 92, 742-748. [CrossRef]

268. Alexander, J.D.; Hallett, S.L.; Stocking, R.W.; Xue, L.; Bartholomew, J.L. Host and parasite populations after a ten-year flood: Manayunkia speciosa and Ceratonova (Syn Ceratomyxa) shasta in the Klamath River. Northwest. Sci. 2014, 88, 219-233. [CrossRef] 
269. Giangrande, A.; Gambi, M.C. The genus Perkinsiana (Polychaeta, Sabellidae) from Antarctica, with descriptions of the new species P. milae and P. borsibrunoi. Zool. Scr. 1997, 26, 267-278. [CrossRef]

270. Murray, J.; Watson, G.; Giangrande, A.; Licciano, M.; Bentley, M. Regeneration as a novel method to culture marine ornamental sabellids. Aquaculture 2013, 410, 129-137. [CrossRef]

271. Chughtai, I.; Knight-Jones, W.E. Burrowing into limestone by sabellid polychaetes. Zool. Scr. 1988, 17, 231-238. [CrossRef]

272. Fonseca, E.A.; Dean, H.K.; Cortés, J. Non-colonial coral macro-borers as indicators of coral reef status in the South Pacific of Costa Rica. Rev. Biol. Trop. 2006, 54, 101-115. [CrossRef] [PubMed]

273. Licciano, M.; Stabili, L.; Giangrande, A. Clearance rates of Sabella spallanzanii and Branchiomma luctuosum (Annelida: Polychaeta) on a pure culture of Vibrio alginolyticus. Water Res. 2005, 39, 4375-4384. [CrossRef]

274. Licciano, M.; Terlizzi, A.; Giangrande, A.; Cavallo, R.A.; Stabili, L. Filter-feeder macroinvertebrates as key players in culturable bacteria biodiversity control: A case of study with Sabella spallanzanii (Polychaeta: Sabellidae). Mar. Environ. Res. 2007, 64, 504-513. [CrossRef]

275. Stabili, L.; Schirosi, R.; Licciano, M.; Giangrande, A. The mucus of Sabella spallanzanii (Annelida, Polychaeta): Its involvement in chemical defense and fertilization success. J. Exp. Mar. Biol. Ecol. 2009, 374, 144-149. [CrossRef]

276. Giangrande, A.; Pierri, C.; Arduini, D.; Borghese, J.; Licciano, M.; Trani, R.; Corriero, G.; Basile, G.; Cecere, E.; Petrocelli, A. An innovative IMTA System: Polychaetes, sponges and macroalgae co-cultured in a southern Italian in-shore mariculture plant (Ionian Sea). J. Mar. Sci. Eng. 2020, 8, 733. [CrossRef]

277. Selim, S.A. New records of sabellid species (Polychaeta: Sabellinae) from the coastal Egyptian waters. Egypt J. Aquat. Res. 2008, $34,108-128$.

278. Giangrande, A.; Caruso, L.; Musco, L.; Licciano, M. Variability among Mediterranean populations of Sabella pavonina (Annelida: Sabellidae). Ital. J. Zool. 2014, 81, 100-111. [CrossRef]

279. Magalhães, W.F.; Bailey-Brock, J.H.; Tovar-Hernández, M.A. An abundant new genus and species of fan worms (Polychaeta: Sabellidae) from Hawaii. Zootaxa 2020, 4763, 85-98. [CrossRef]

280. Capa, M.; Nishi, E.; Tanaka, K.; Fujikura, K. First record of a Bispira species (Sabellidae: Polychaeta) from a hydrothermal vent. Mar. Biodivers. Rec. 2013, 6, e68. [CrossRef]

281. Amon, D.J.; Glover, A.G.; Wiklund, H.; Marsh, L.; Linse, K.; Rogers, A.D.; Copley, J.T. The discovery of a natural whale fall in the Antarctic deep sea. Deep Sea Res. Part. II Top. Stud. Ocean. 2013, 92, 87-96. [CrossRef]

282. Cordes, E.E.; Carney, S.L.; Hourdez, S.; Carney, R.S.; Brooks, J.M.; Fisher, C.R. Cold seeps of the deep Gulf of Mexico: Community structure and biogeographic comparisons to Atlantic Equatorial belt seep communities. Deep Sea Res. Part. I Ocean. Res. Pap. 2007, 54, 637-653. [CrossRef]

283. Sellanes, J.; Quiroga, E.; Neira, C. Megafauna community structure and trophic relationships at the recently discovered Concepción methane seep area, Chile, $\sim 36^{\circ}$ S. ICES. Mar. Sci. 2008, 65, 1102-1111. [CrossRef]

284. Goffredi, S.K.; Tilic, E.; Mullin, S.W.; Dawson, K.S.; Keller, A.; Lee, R.W.; Wu, F.; Levin, L.A.; Rouse, G.W.; Cordes, E.E. Methanotrophic bacterial symbionts fuel dense populations of deep-sea feather duster worms (Sabellida, Annelida) and extend the spatial influence of methane seepage. Sci. Adv. 2020, 6, eaay8562. [CrossRef]

285. Hutchings, P.; Murray, A. Taxonomy of the polychaetes from the Hawkesbury River and the Southern estuaries of New South Wales, Australia. Rec. Aust. Mus. 1984, 36, 1-119. [CrossRef]

286. Lardicci, C.; Castelli, A. Desdemona ornata Banse, 1957 (Polychaeta, Sabellidae, Fabricinae) New record in the Mediterranean Sea. Oebalia 1986, 13, 195-201.

287. Castelli, A.; Galletti, C.; Lardicci, C. Structure of benthic communities of brackish-water microhabitats: Spatial and temporal variations. MAP Tech. Rep. Ser. (UNEP) 1988, 22, 19-46.

288. Panagopoulos, D.; Nicolaidou, A. A population of Desdemona ornata Banse, 1957 (Polychaeta, Sabellidae) settled in a fully marine habitat of the Mediterranean. Oebalia 1989, 16, 35-39.

289. Glasby, C.J.; Timm, T.; Muir, A.I.; Gil, J. Catalogue of non-marine Polychaeta (Annelida) of the World. Zootaxa 2009, $2070,1-52$. [CrossRef]

290. Hossain, M.B.; Marshall, D.J. Benthic infaunal community structuring in an acidified tropical estuarine system. Aquat. Biosyst. 2014, 10, 1-12. [CrossRef] [PubMed]

291. Hernández-Alcántara, P.; Cortés-Solano, J.D.; Medina-Cantú, N.M.; Avilés-Díaz, A.L.; Solís-Weiss, V. Polychaete diversity in the estuarine habitats of Términos lagoon, Southern Gulf of Mexico. Mem. Mus. Vic. 2014, 71, 97-107. [CrossRef]

292. Hsieh, H.L. Laonome albicingillum, a new fan worm species (Polychaeta, Sabellidae, Sabellinae) from Taiwan. Proc. Biol. Soc. Wash. 1995, 108, 130-135.

293. Hsieh, H.L. Self-fertilization-a potential fertilization mode in an estuarine sabellid polychaete. Mar. Ecol. Prog. Ser. 1997, 147, 143-148. [CrossRef]

294. Capa, M.; van Moorsel, G.; Tempelman, D. The Australian feather-duster worm Laonome calida Capa, 2007 (Annelida: Sabellidae) introduced into European inland waters? Bioinvasions Rec. 2014, 3, 1-11. [CrossRef]

295. Bonar, D.B. Feeding and tube construction in Chone mollis Bush (Polychaeta, Sabellidae). J. Exp. Mar. Biol. Ecol. 1972, 9, 1-18. [CrossRef]

296. Fitzsimons, G. Feeding and tube building in Sabellastarte magnifica (Shaw) (Sabellidae: Polychaeta). Bull. Mar. Sci. 1965, 15, $642-671$. 
297. Licciano, M.; Murray, J.M.; Watson, G.J.; Giangrande, A. Morphological comparison of the regeneration process in Sabella spallanzanii and Branchiomma luctuosum (Annelida, Sabellida). Invertebr. Biol. 2012, 131, 40-51. [CrossRef]

298. Jumars, P.A.; Dorgan, K.M.; Lindsay, S.M. Diet of worms emended: An update of polychaete feeding guilds. Ann. Rev. Mar. Sci 2015, 7, 497-520. [CrossRef]

299. Jones, M.L. On the Caobangiidae, a new family of the Polychaeta, with a redescription of Caobangia billeti Giard. Smithson. Contr. Zool. 1974, 1-55. [CrossRef]

300. Kuris, A.M.; Culver, C.S. An introduced sabellid polychaete pest infesting cultured abalones and its potential spread to other California gastropods. Invertebr. Biol. 1999, 118, 391-403. [CrossRef]

301. Ruck, K.R.; Cook, P.A. Sabellid infestations in the shells of South African molluscs: Implications for abalone mariculture. J. Shellfish Res. 1998, 17, 693-699.

302. Kupriyanova, E.K.; Badyaev, A.V. Ecological correlates of Arctic Serpulidae (Annelida, Polychaeta) distributions. Ophelia 1998, 49, 181-193. [CrossRef]

303. Kupriyanova, E.K.; Nishi, E.; ten Hove, H.A.; Rzhavsky, A.V. A review of life history patterns in serpulimorph polychaetes: Ecological and evolutionary perspectives. Ocean. Mar. Biol. Ann. Rev. 2001, 39, 1-101.

304. Charles, F.; Jordana, E.; Amouroux, J.-M.; Gremare, A.; Desmalades, M.; Zudaire, L. Reproduction, recruitment and larval metamorphosis in the serpulid polychaete Ditrupa arietina (O.F. Muller). Estuar. Coast. Shelf Sci. 2003, 57, 435-443. [CrossRef]

305. Goffredi, S.K.; Johnson, S.; Tunnicliffe, V.; Caress, D.; Clague, D.; Escobar, E.; Paduan, J.B.; Rouse, G.; Salcedo, D.L.; Soto, L.A.; et al. Hydrothermal vent fields discovered in the Southern Gulf of California clarify role of habitat in augmenting regional diversity. Proc. R. Soc. B Biol. Sci. 2017, 284, 20170817. [CrossRef] [PubMed]

306. Kupriyanova, E.K.; Nishi, E.; Kawato, M.; Fujiwara, Y. New records of Serpulidae (Annelida, Polychaeta) from hydrothermal vents of North Fiji, Pacific Ocean. Zootaxa 2010, 2389, 57-68. [CrossRef]

307. Vinn, O.; Kupriyanova, E.K.; Kiel, S. Systematics of serpulid tubeworms (Annelida, Polychaeta) from Cretaceous and Cenozoic hydrocarbon-seep deposits in North America and Europe. Neues Jahrb. Geol. Paläontol. 2012, 265, 315-325. [CrossRef]

308. Juniper, S.K.; Sibuet, M. Cold seep benthic communities in Japan subduction zones: Spatial organisation, trophic strategies and evidence for temporal evolution. Mar. Ecol. Prog. Ser. 1987, 40, 115-126. [CrossRef]

309. Olu, K.; Duperret, A.; Sibuet, M.; Foucher, J.-P.; Fiala-Médioni, A. Structure and distribution of cold seep communities along the Peruvian Active Margin: Relationship to geological and fluid patterns. Mar. Ecol. Progr. Ser. 1996, 132, 109-125. [CrossRef]

310. Segonzac, M.; Hekinian, R.; Auzende, J.; Francheteau, J. Recently discovered animal communities on the South East Pacific Rise (17-19 S and the Eastern Microplaque Region). Cah. Biol. Mar. 1997, 38, 140-141.

311. López-González, P.; Rodríguez, E.; Gili, J.-M.; Segonzac, M. New records on sea anemones (Anthozoa: Actiniaria) from hydrothermal vents and cold seeps. Zool. Verh. 2003, 345, 215-243.

312. Sibuet, M.; Olu, K. Biogeography, biodiversity and fluid dependence of deep-sea cold-seep communities at active and passive margins. Deep Sea Res. Part. II Top. Stud. Ocean. 1998, 45, 517-567. [CrossRef]

313. Mak, P.; Huang, Z. The salinity tolerance of the serpulid polychaete, Hydroides elegans (Haswell, 1883), and its possible applications in bio-antifouling. The marine flora and fauna of Hong Kong and Southern China. Ecol. Morph. Behav. Phys. 1982, 1, 817-823.

314. Knight-Jones, P. Behaviour, setal inversion and phylogeny of Sabellida (Polychaeta). Zool. Scr. 1981, 10, 183-202. [CrossRef]

315. Dill, L.M.; Fraser, A.H.G. The worm re-turns: Hiding behavior of a tube-dwelling marine polychaete, Serpula vermicularis. Behav. Ecol. 1997, 8, 186-193. [CrossRef]

316. Pan, J.; Marcoval, M.A. Top-down effects of an exotic serpulid polychaete on natural plankton assemblage of estuarine and brackish systems in the SW Atlantic. J. Coast. Res. 2014, 30, 1226-1235. [CrossRef]

317. Jordana, E.; Charles, F.; Gremare, A.; Amouroux, J.-M.; Chretiennot-Dinet, M.-J. Food sources, ingestion and absorption in the suspension-feeding polychaete, Ditrupa arietina (O. F. Muller). J. Exp. Mar. Biol. Ecol. 2001, 266, 219-236. [CrossRef]

318. Bailey-Brock, J.H. Polychaetes from Fijian coral reefs. Pac. Sci. 1985, 39, 195-220.

319. Nishi, E. Serpulid polychaetes associated with living and dead corals at Okinawa Island, Southwest Japan. Publ. Seto Mar. Biol. Lab. 1996, 36, 305-318. [CrossRef]

320. Marsden, J.R. Coral preference behaviour by planktotrophic larvae of Spirobranchus giganteus corniculatus (Serpulidae: Polychaeta). Coral Reefs 1987, 6, 71-74. [CrossRef]

321. Hunte, W.; Conlin, B.E.; Marsden, J.R. Habitat selection in the tropical polychaete Spirobranchus giganteus. I. Distribution on corals. Mar. Biol. 1990, 104, 87-92. [CrossRef]

322. Marsden, J.R. Light responses of the planktotrophic larva of the serpulid polychaete Spirobranchus polycerus. Mar. Ecol. Prog. Ser. 1990, 58, 225-233.

323. Williams, G.B. The effect of extracts of Fucus serratus in promoting the settlement of larvae of Spirorbis borealis (Polychaeta). J. Mar. Biol. Assoc. UK 1964, 44, 397-414. [CrossRef]

324. Gee, J.M. Chemical stimulation of settlement in larvae of Spirorbis rupestris (Serpulidae). Anim. Behav. 1965, 13, 181-186. [CrossRef]

325. Hartman, O. Catalogue of the polychaetous annelids of the world. Part II. Occ. Pap. Allan Hancock Found. 1959, $23,355-628$.

326. Darling, J.A.; Carlton, J.T. A framework for understanding marine cosmopolitanism in the Anthropocene. Front. Mar. Sci. 2018, 5 , 1-293. [CrossRef]

327. Hutchings, P.; Kupriyanova, E. Cosmopolitan polychaetes-fact or fiction? Personal and historical perspectives. Invertebr. Syst. 2018, 32, 1-9. [CrossRef] 
328. Briggs, J.C. Marine Zoogeography; McGraw-Hill: New York, NY, USA, 1974; pp. 1-475.

329. McClain, C.R.; Schlacher, T.A. On some hypotheses of diversity of animal life at great depths on the sea floor. Mar. Ecol. 2015, 36, 849-872. [CrossRef]

330. Higgs, N.D.; Attrill, M. Biases in biodiversity: Wide-ranging species are discovered first in the deep sea. Front. Mar. Sci. 2015, 2, 61. [CrossRef]

331. Giangrande, A.; Licciano, M. Factors influencing latitudinal pattern of biodiversity: An example using Sabellidae (Annelida, Polychaeta). Biodiv. Conserv. 2004, 13, 1633-1646. [CrossRef]

332. Banse, K. Beiträge zur kenntnis der gattungen Fabricia, Manayunkia und Fabriciola (Sabellidae, Polychaeta). Zool. Jahrb. (Abt. Syst. Okol. Geogr. Tiere) 1956, 84, 415-438.

333. Bourne, A.G. On Haplobranchus, a new genus of Capitobranchiate annelids. J. Cell Sci. 1883, 23, $168-176$.

334. Annenkova, N.P. Über Die Pontokaspischen Polychaeten. II. Die Gattungen Hypaniola, Parhypania, Fabricia und Manajunkia. Ann. Mussée Zool. L'Academie des Sci. L'URSS, Leningrad 1928, 30, 13-20.

335. Day, J.H. The polychaete fauna of South Africa Part 8: New species and records from grab samplings and dreddings. Bull. Brit. Mus. (Nat. Hist.) Zool. 1963, 10, 381-445. [CrossRef]

336. Perkins, T.H. Revision of Demonax Kinberg, Hypsicomus Grube, and Notaulax Tauber, with a review of Megalomma Johansson from Florida (Polychaeta: Sabellidae). Proc. Biol. Soc. Wash. 1984, 97, 285-368.

337. Knight-Jones, P.; Perkins, T.H. A revision of Sabella and Bispira and Stylomma. (Sabellidae: Polychaeta). Zool. J. Linn. Soc. 1998, 123, 385-467. [CrossRef]

338. Knight-Jones, P.; Mackie, A.S. A revision of Sabellastarte (Polychaeta: Sabellidae). J. Nat. Hist. 2003, 37, 2269-2301. [CrossRef]

339. Hartman, O. Abyssal polychaetous annelids from the Mozambique Basin off Southeast Africa, with a compendium of abyssal polychaetous annelids from world-wide Areas. J. Fish. Res. Board Can. 1971, 28, 1407-1428. [CrossRef]

340. Uschakov, P.V. Bathypelagic and deepwater forms of marine polychaetes from Kamchatka Area of the Pacific. Issled. Fauny Morej USSR 1952, 3, 103-112.

341. Levenstein, R.Y. Polychaeta from deep water in the Bering Sea. Proc. Inst. Oceanol. USSR Acad. Sci 1961, 46, 147-178.

342. Levenstein, R.Y. Polychaeta. In Pacific Ocean. Biology. Deep-Sea Fauna; Zenkevitch, L.A., Ed.; Nauka: Moscow, Russia, 1969; pp. 52-62. (In Russian)

343. Belyaev, G.M. Hadal Bottom Fauna of the World Ocean; Institute of Oceanology, USSR Academy of Sciences: Moscow, Russia, 1972; pp. 1-199.

344. Belyaev, G.M. Glubokovodnye Okeanicheskie Zheloba i Ikh Fauna [Deep-Sea Oceanic Trenches and Their Fauna]; Nauka: Moscow, Russia, 1989; pp. 1-256. (In Russian)

345. Moore, J.P. Additional new species of Polychaeta from the North Pacific. Proc. Acad. Nat. Sci. Phil. 1906, 58, 217-260.

346. Moore, J.P. The Polychætous annelids Dredged by the U. S. S. "Albatross" off the Coast of Southern California in 1904. IV. Spionidae to Sabellariidae. Proc. Acad. Nat. Sci. Phil. 1923, 7, 179-259.

347. Hartman, O. Deep-water benthic polychaetous annelids off New England to Bermuda and other North Atlantic Areas. Occ. Pap. Allan Hancock Found. 1965, 28, 1-378.

348. Méndez, N. Trophic categories of soft-bottom epibenthic deep-sea polychaetes from the Southeastern Gulf of California (Mexico) in relation with environmental variables. Pan Am. J. Aquat. Sci. 2013, 8, 299-311.

349. Zibrowius, H. Review of Serpulidae (Polychaeta) from depths exceeding 2000 meters. In Essays on Polychaetous Annelids in Memory of Dr. Olga Hartman; Reish, D.J., Fauchald, K., Eds.; Allan Hancock Press: Los Angeles, CA, USA, 1977; pp. $289-306$.

350. Kirkergaard, J.B. Benthic Polychaeta from depths exceeding 6000 m. Galathea Rep. 1956, 2, 63-78.

351. Paterson, G.L.; Glover, A.G.; Froján, C.R.B.; Whitaker, A.; Budaeva, N.; Chimonides, J.; Doner, S. A Census of abyssal polychaetes. Deep Sea Res. Part. II Top. Stud. Ocean. 2009, 56, 1739-1746. [CrossRef]

352. Kupriyanova, E.K. Deep-water Serpulidae (Annelida, Polychaeta) from the Kurile-Kamchatka Trench. 2. Genera Bathyditrupa, Bathyvermilia and Protis. Zool. Zhurnal 1993, 72, 21-28.

353. Kupriyanova, E.K. Deep-water Serpulidae (Annelida, Polychaeta) from the Kurile-Kamchatka Trench. 1. Genus Hyalopomatus. Zool. Zhurnal 1993, 72, 145-152.

354. Sanfilippo, R. New species of Hyalopomatus Marenzeller, 1878 (Annelida, Polychaeta, Serpulidae) from Recent Mediterranean deep-water coral mounds and comments on some congeners. Zoosystema 2009, 31, 147-161. [CrossRef]

355. Kupriyanova, E.K.; Bailey-Brock, J.; Nishi, E. New records of Serpulidae (Annelida, Polychaeta) collected by R/V “Vityaz" from bathyal and abyssal depths of the Pacific Ocean. Zootaxa 2011, 2871, 43-60. [CrossRef]

356. Kupriyanova, E.K.; Vinn, O.; Taylor, P.D.; Schopf, J.W.; Kudryavtsev, A.B.; Bailey-Brock, J. Serpulids living deep: Calcareous tubeworms beyond the abyss. Deep Sea Res. Part. I Ocean. Res. 2014, 90, 91-104. [CrossRef]

357. Kupriyanova, E.K.; Nishi, E. New records of the deep-sea Nogrobs grimaldii (Serpulidae: Annelida). Mar. Biodivers. Rec. 2011, 4, e74. [CrossRef]

358. Rouse, G.W.; Kupriyanova, E.K. Laminatubus (Serpulidae, Annelida) from Eastern Pacific hydrothermal vents and methane seeps, with description of two new species. Zootaxa 2021, 4915, 1-27. [CrossRef]

359. Thorp, C.H.; Pyne, S.; West, S.A. Hydroides ezoensis Okuda, a fouling serpulid new to British coastal waters. J. Nat. Hist. 1987, 21, 863-877. [CrossRef] 
360. Zibrowius, H. A propos des pretendud “Recifs de Serpulidae” de l'lle Rousse, Corse (Mediterranee Nord-Occidentale). Mesogee 1991, 50, 71-74.

361. Zibrowius, H. Assessing scale and impact of ship-transported alien fauna in the Mediterranean. In Alien Marine Organisms Introduced by Ships in the Mediterranean and Black Seas; Briand, F., Ed.; CIESM Workshop Monographs: Monaco, France, 2002; Volume 20, pp. 62-68.

362. Lewis, J.A.; Watson, C.; Harry, A. Establishment of the Caribbean serpulid tubeworm Hydroides sanctaecrucis Krøyer [in] Mörch, 1863, in Northern Australia. Biol. Invasions 2006, 8, 665-671. [CrossRef]

363. Giangrande, A.; Licciano, M.; Pagliara, P.; Gambi, M.C. Gametogenesis and larval development in Sabella spallanzanii (Polychaeta: Sabellidae) from the Mediterranean Sea. Mar. Biol. 2000, 136, 847-861. [CrossRef]

364. Read, G.; Inglis, G.; Stratford, P.; Ahyong, S. Arrival of the alien fanworm Sabella spallanzanii (Gmelin, 1791) (Polychaeta: Sabellidae) in two New Zealand harbours. Aquat. Invasions 2011, 6, 273-279. [CrossRef]

365. Çinar, M.E. Alien polychaete species worldwide: Current status and their impacts. J. Mar. Biol. Assoc. UK 2013, 93, 1257-1278. [CrossRef]

366. Morais, P.; Reichard, M. Cryptic invasions: A review. Sci. Total Environ. 2018, 613, 1438-1448. [CrossRef]

367. Chapman, J.W.; Carlton, J.T. A test of criteria for introduced species: The global invasion by the isopod Synidotea laevidorsalis (Miers, 1881). J. Crust. Biol. 1991, 11, 386-400. [CrossRef]

368. Wolff, W.J. Non-Indigenous marine and estuarine species in the Netherlands. Zool. Med. Leiden 2005, 79, 1-116.

369. Patti, F.; Gambi, M. Phylogeography of the invasive polychaete Sabella spallanzanii (Sabellidae) based on the nucleotide sequence of internal transcribed spacer 2 (ITS2) of nuclear rDNA. Mar. Ecol. Prog. Ser. 2001, 215, 169-177. [CrossRef]

370. Ahyong, S.T.; Kupriyanova, E.; Burghardt, I.; Sun, Y.; Hutchings, P.A.; Capa, M.; Cox, S.L. Phylogeography of the invasive Mediterranean fan worm, Sabella spallanzanii (Gmelin, 1791), in Australia and New Zealand. J. Mar. Biol. Assoc. UK 2017, 97, 985-991. [CrossRef]

371. Pabis, K.; Krodkiewska, M.; Cebulska, K. Alien freshwater polychaetes Hypania invalida (Grube 1860) and Laonome calida Capa, 2007 in the Upper Odra River (Baltic Sea catchment area). Knowl. Manag. Aquat. Ecosyst. 2017, 418, 46. [CrossRef]

372. Boltachova, N.; Lisitskaya, E.; Frolenko, L.; Kovalev, E.; Barabashin, T. The finding of polychaete Laonome calida Capa, 2007 (Annelida: Sabellidae) in the Southeast Sea of Azov. Russ. J. Biol. Invasions 2017, 8, 303-306. [CrossRef]

373. Tamulyonis, A.Y.; Gagaev, S.Y.; Stratanenko, E.A.; Zuyev, Y.A.; Potin, V.V. Invasion of the Polychaeta Laonome xeprovala Bick \& Bastrop, 2018 (Sabellidae, Polychaeta) into the estuary of the Luga and Khabolovka Rivers (Luga Bay, Gulf of Finland). Russ. J. Biol. Invasions 2020, 11, 148-154. [CrossRef]

374. Tovar-Hernández, M.A.; Yáñez-Rivera, B.; Bortolini-Rosales, J.L. Reproduction of the invasive fan worm Branchiomma bairdi (Polychaeta: Sabellidae). Mar. Biol. Res. 2011, 7, 710-718. [CrossRef]

375. Roman, S.; Perez-Ruzafa, A.; Lopez, E. First record in the Western Mediterranean Sea of Branchiomma boholense (Grube, 1878) (Polychaeta: Sabellidae), an alien species of Indo-Pacific origin. Cah. Biol. Mar. 2009, 50, 241-250.

376. Arias, A.; Giangrande, A.; Gambi, M.C.; Anadón, N. Biology and new records of the invasive species Branchiomma bairdi (Annelida: Sabellidae) in the Mediterranean Sea. Mediterr. Mar. Sci. 2013, 10, 162-171. [CrossRef]

377. Ramalhosa, P.; Camacho-Cruz, K.; Bastida-Zavala, R.; Canning-Clode, J. First record of Branchiomma bairdi McIntosh, 1885 (Annelida: Sabellidae) from Madeira Island, Portugal (Northeastern Atlantic Ocean). Bioinvasions Rec. 2014, 3, 235-239. [CrossRef]

378. Cepeda, D.; Rodríguez-Flores, P. First record of the invasive worm Branchiomma bairdi (Annelida: Sabellidae) in the Balearic Sea (Western Mediterranean). J. Mar. Biol. Assoc. UK 2018, 98, 1955-1963. [CrossRef]

379. Del Pasqua, M.; Schulze, A.; Tovar-Hernández, M.A.; Keppel, E.; Lezzi, M.; Gambi, M.C.; Giangrande, A. Clarifying the taxonomic status of the alien species Branchiomma bairdi and Branchiomma boholense (Annelida: Sabellidae) using molecular and morphological evidence. PLoS ONE 2018, 13, e0197104. [CrossRef]

380. Hewitt, C.L.; Campbell, M.L.; Thresher, R.E.; Martin, R.B.; Boyd, S.; Cohen, B.F.; Currie, D.R.; Gomon, M.F.; Keough, M.J.; Lewis, J.A.; et al. Introduced and cryptogenic species in Port Phillip Bay, Victoria, Australia. Mar. Biol. 2004, 144, 183-202. [CrossRef]

381. Zenetos, A.; Çinar, M.E.; Pancucci-Papadopoulou, M.A.; Harmelin, J.G.; Furnari, G.; Andaloro, F.; Bellou, N.; Streftaris, N.; Zibrowius, $\mathrm{H}$. Annotated list of marine alien species in the Mediterranean with records of the worst invasive species. Mediterr. Mar. Sci. 2005, 6, 63-118. [CrossRef]

382. Gravili, C.; Belmonte, G.; Cecere, E.; Denitto, F.; Giangrande, A.; Guidetti, P.; Longo, C.; Mastrototaro, F.; Moscatello, S.; Petrocelli, A. Nonindigenous species along the Apulian Coast, Italy. Chem. Ecol. 2010, 26, 121-142. [CrossRef]

383. Giangrande, A.; Montanaro, P.; Castelli, A. On some Amphicorina (Polychaeta, Sabellidae) species from the Mediterranean coast, with the description of A. grahamensis. Ital. J. Zool. 1999, 66, 195-203. [CrossRef]

384. Zenetos, A.; Gofas, S.; Verlaque, M.; Çinar, M.E.; Garcia Raso, J.E.; Bianchi, C.N.; Morri, C.; Azzurro, E.; Bilecenoglu, M.; Froglia, C.; et al. Alien species in the Mediterranean Sea by 2010. A contribution to the application of European Union's Marine Strategy Framework Directive (MSFD). Part I. Spatial distribution. Mediter. Mar. Sci. 2010, 11, 381. [CrossRef]

385. Faasse, M.A.; Giangrande, A. Description of Bispira polyomma n. sp. (Annelida: Sabellidae): A probable introduction to the Netherlands. Aquat. Invasions 2012, 7, 591-598. [CrossRef]

386. Capa, M.; Murray, A. A taxonomic guide to the fanworms (Sabellidae, Annelida) of Lizard Island, Great Barrier Reef, Australia, including new species and new records. Zootaxa 2015, 4019, 98-167. [CrossRef] [PubMed] 
387. Khedhri, I.; Tovar-Hernández, M.A.; Bonifácio, P.; Ahmed, A.; Aleya, L. First report of the invasive species Branchiomma bairdi McIntosh, 1885 (Annelida: Sabellidae) along the Tunisian Coast (Mediterranean Sea). Bioinvasions Rec. 2017, 6, 139-145. [CrossRef]

388. Abdelnaby, F. Alien polychaete species and the first record of Branchiomma bairdi (McIntosh, 1885) from the Suez Canal and the Mediterranean coast of Egypt. Egypt. J. Aquat. Biol. Fish. 2020, 24, 13-32. [CrossRef]

389. Knight-Jones, P.; Knight-Jones, W.; Ergen, Z. Sabelliform Polychaetes, mostly from Turkey's Aegean coast. J. Nat. Hist. 1991, 25, 837-858.

390. Çinar, M.E. Polychaetes from the coast of Northern Cyprus (Eastern Mediterranean Sea), with Two new records for the Mediterranean Sea. Cah. Biol. Mar. 2005, 46, 143-160.

391. Keppel, E.; Tovar Hernández, M.A.; Ruiz, G.M. First record and establishment of Branchiomma coheni (Polychaeta: Sabellidae) in the Atlantic Ocean and review of non indigenous species of the genus. Zootaxa 2015, 4058, 499-518. [CrossRef]

392. Tovar-Hernández, M.A.; Dean, H.A. New gregarious sabellid worm from the Gulf of California reproducing by dpontaneous fission (Polychaeta, Sabellidae). J. M. Biol. Assoc. UK 2014, 94, 935-946. [CrossRef]

393. Bianchi, C. Serpuloidea (Annelida, Polychaeta) Delle Lagune Costiere Laziali e Campane. Annali del Museo Civico di Storia Naturale di Genova 1983, 84, 231-243.

394. Arvanitides, C. Polychaete fauna of the Aegean Sea: Inventory and new information. Bull. Mar. Sci. 2000, 66, 73-96.

395. Simboura, N.; Nicolaidou, A. The Polychaetes (Annelida, Polychaeta) of Greece: Checklist, distribution and ecological characteristics. Monographs on Marine Sciences, Ser. 4; National Center for Marine Research: Athens, Greece, 2001; pp. 1-115.

396. Licciano, M.; Giangrande, A.; Gambi, M.C. Reproduction and simultaneous hermaphroditism in Branchiomma luctuosum (Polychaeta, Sabellidae) from the Mediterranean Sea. Invertebr. Biol. 2002, 121, 55-65. [CrossRef]

397. Mastrototaro, F.; Petrocelli, A.; Cecere, E.; Matarrese, A. Non indigenous species settle down in the Taranto Seas. Biogeographia 2004, 25, 47-54. [CrossRef]

398. Çinar, M.E.; Bilecenoglu, M.; Öztürk, B.; Can, A. New records of alien species on the Levantine coast of Turkey. Aquat. Invasions 2006, 1, 84-90. [CrossRef]

399. El Haddad, M.; Capaccioni Azzati, R.; García-Carrascosa, A.M. Branchiomma luctuosum (Polychaeta: Sabellidae): A non-indigenous species at Valencia Port (Western Mediterranean Sea, Spain). Mar. Biodivers. Rec. 2008, 1, e61. [CrossRef]

400. Giangrande, A.; Licciano, M. Revision of the species of Megalomma (Polychaeta, Sabellidae) from the Mediterranean Sea, with the description of M. messapicum n. sp. Ital. J. Zool. 2008, 75, 207-217. [CrossRef]

401. Tanduo, V.; Golemaj, A.; Crocetta, F. Citizen-science detects the arrival and establishment of Branchiomma luctuosum (Grube, 1870) (Annelida: Polychaeta: Sabellidae) in Albania. Biodivers. Data J. 2020, 8, e54790. [CrossRef]

402. De Matos Nogueira, J.M.; Rossi, M.C.S.; López, E. Intertidal species of Branchiomma Kolliker and Pseudobranchiomma Jones (Polychaeta: Sabellidae: Sabellinae) occurring on rocky shores along the state of Sao Paulo, Southeastern Brazil. Zool. Stud. 2006, 45, 586-610.

403. Hartmann-Schröder, G. Teil 8. Die Polychaeten der Subtropisch-Antiborealen Westküste Australiens (Zwischen Cervantes im Norden und Cape Naturliste im Suden). Mitt. Hamb. Zool. Mus. Inst. 1982, 79, 51-118.

404. Ceberio, A.; Martínez, J.; Aguirrezabalaga, F. Presencia de Desdemona ornata Banse, 1957 (Polychaeta, Sabellidae) en las costas de La Península Ibérica, Golfo de Vizcaya. Munibe 1998, 50, 37-41.

405. Smith, P.; Perrett, J.; Garwood, P.; Moore, G. Two additions to the UK marine fauna: Desdemona ornata Banse, 1957 (Polychaeta, Sabellidae) and Grandidierella japonica Stephensen, 1938 (Amphipoda, Gammaridea). Newsl. Porcupine Mar. Nat. Hist. Soc. 1999, 2, 8-11.

406. Çinar, M.E.; Dagli, E.; Açik, S. Annelids (Polychaeta and Oligochaeta) from the Sea of Marmara, with descriptions of five new species. J. Nat. Hist. 2011, 45, 2105-2143. [CrossRef]

407. Carvalho, S.; Pereira, P.; Pereira, F.; de Pablo, H.; Vale, C.; Gaspar, M.B. Factors structuring temporal and spatial dynamics of macrobenthic communities in a eutrophic coastal lagoon (Óbidos Lagoon, Portugal). Mar. Environ. Res. 2011, 71, 97-110. [CrossRef]

408. Faasse, M. Dispersal of the invasive tubeworms Desdemona ornata and Pseudopolydora paucibranchiata to the Netherlands (Polychaeta: Sedentaria). Nederl. Faun. Med. 2016, 46, 49-56.

409. McArthur, M. Systematics and Introduced Status of Euchone (Polychaeta: Sabellidae) in Port Phillip Bay, and the Feeding Biology of Euchone limnicola. Bachelor's Thesis, Victoria University of Technology, Melbourne, Australia, 1997.

410. Guyonnet, B.; Borg, D. Premier signalement de l'espèce introduite Euchone limnicola Reish, 1959 (Polychaeta: Sabellidae) sur ses Côtes Françaises de la Mer du Nord (Grand Port Maritime de Dunkerque). Cah. Nat. Observat. Mar. 2015, 4, 15-23.

411. 411. Dane, L Morphological and Genetic Variation in the Cryptic Species Complex Myxicola infundibulum (Polychaeta, Sabellidae), and its Introduction to Australia. Master's Thesis, University of Melbourne, Melbourne, Australia, 2008.

412. Keppel, E.; Ruiz, G.; Tovar-Hernández, M. Re-description of Parasabella fullo (Grube, 1878) (Polychaeta: Sabellidae) and diagnostic characteristics for detection in California. Eur. Zool. J. 2020, 87, 105-115. [CrossRef]

413. Currie, D.; McArthur, M.; Cohen, B. Exotic Marine Pests in the Port. of Geelong, Victoria. Report 8; Marine and Freshwater Resources Institute: Queenscliff, Australia, 1998; pp. 1-57.

414. Coles, S.L. Historical and recent introductions of non-indigenous marine species into Pearl Harbor, Oahu, Hawaiian Islands. Mar. Biol. 1999, 135, 147-158. [CrossRef] 
415. Eldredge, L.G.; Smith, C.A. Guidebook of Introduced Marine Species in Hawaii; Bishop Museum Technical Report 21; Bishop Museum: Honolulu, Hawaii, USA, 2001.

416. Coles, S.; Eldredge, L.G. Nonindigenous species introductions on coral reefs: A need for information. Pac. Sci. 2002, 56, 191-209. [CrossRef]

417. Culver, C.S.; Kuris, A.M.; Beede, B. Identification and Management of the Exotic Sabellid Pest in California Cultured Abalone; Californian Sea Grant College System: La Jolla, CA, USA, 1997.

418. Moore, J.D.; Juhasz, C.I.; Robbins, T.T.; Grosholz, E.D. The introduced sabellid polychaete Terebrasabella heterouncinata in California: Transmission, methods of control and survey for presence in native gastropod populations. J. Shellfish Res. 2007, 26, 869-876. [CrossRef]

419. Moreno, R.A.; Neill, P.E.; Rozbaczylo, N. Native and non-indigenous boring polychaetes in Chile: A threat to native and commercial mollusc species. Rev. Chil. Hist. Nat. 2006, 79, 263-278. [CrossRef]

420. Dittmann, S.; Rolston, A.; Benger, S.N.; Kupriyanova, E.K. Habitat Requirements, Distribution and Colonisation of the Tubeworm Ficopomatus Enigmaticus in the Lower Lakes and Coorong; Report for the South Australian Murray-Darling Basin Natural Resources Management Board; Department of Environment and water: Adelaide, Australia, 2009; pp. 1-99.

421. Grosse, M.; Pérez, R.; Juan-Amengual, M.; Pons, J.; Capa, M. The elephant in the room-first record of invasive gregarious species of serpulids (Calcareous Tube Annelids) in Majorca (Western Mediterranean). Sci. Mar. 2021, in press.

422. Assis, J.D.; Alonso, C.; Christoffersen, M.L. First record of Ficopomatus uschakovi (Pillai, 1960) Serpulidae (Polychaeta: Annelida) for the Western Atlantic. Rev. Nord. Biol. 2008, 19, 51-58.

423. Bastida-Zavala, R.; García-Madrigal, S. First record in the Tropical Eastern Pacific of the exotic species Ficopomatus uschakovi (Polychaeta, Serpulidae). ZooKeys 2012, 238, 45-55. [CrossRef]

424. Liñero-Arana, I.; Díaz-Díaz, Ó. Presencia del poliqueto exótico Ficopomatus uschakovi (Polychaeta: Serpulidae) en Venezuela: Descripción y comentarios sobre su distribución. Interciencia 2012, 37, 234-237.

425. Arteaga-Flórez, C.; Fernández-Rodríguez, V.; Londoño-Mesa, M.H. First record of the polychaete Ficopomatus uschakovi (Pillai, 1960) (Annelida, Serpulidae) in the Colombian Caribbean, South America. Zookeys 2014, 371, 1-11. [CrossRef] [PubMed]

426. Zibrowius, H. Les espèces Méditerrannéennes du genre Hydroides (Polychaeta Serpulidae). Remarques sur le prétendu polymorphisme de Hydroides uncinata. Téthys 1971, 2, 691-746.

427. Zibrowius, H. Introduced invertebrates: Examples of success and nuisance in the European Atlantic and in the Mediterranean. Introduced species in European coastal waters. Ecosyst. Res. Rep. 1994, 8, 44-49.

428. Cohen, A.N.; Harris, L.H.; Bingham, B.L.; Carlton, J.T.; Chapman, J.W.; Lambert, C.C.; Lambert, G.; Ljubenkov, J.C.; Murray, S.N.; Rao, L.C. Project Report for the Southern California Exotics Expedition; A Rapid Assessment Survey of Exotic Species in Sheltered Coastal Waters California Department of Fish and Game, Sacramento CA State Water Resources Control Board, Sacramento CA National Fish and Wildlife Foundation: San Francisco, CA, USA, 2002; pp. 1-37.

429. Carlton, J.T.; Eldredge, L.G. Marine bioinvasions of Hawai' $i$; Bernice, P., Ed.; Bishop Museum Press: Honolulu, HI, USA, 2009; pp. $1-202$.

430. Pettengill, J.; Wendt, D.; Schug, M.D.; Hadfield, M. Biofouling likely serves as a major mode of dispersal for the polychaete tubeworm Hydroides elegans as inferred from microsatellite loci. Biofouling 2007, 23, 161-169. [CrossRef]

431. Gruet, Y.; Hèral, M.; Robert, J.M. Premières observations sur l'introduction de la faune associée au naissain d'huîtres Japonaises Crassostrea gigas (Thunberg), importé sur la Côte Atlantique Française. Cah. Biol. Mar. 1976, 17, 173-184.

432. Zibrowius, H. Introduction du polychete Serpulidae Japonais Hydroides ezoensis sur la Cote, Atlantique Frnacoise et remarques sur la propagation d'autre espeies de Serpulidae. Tethys 1978, 8, 141-150.

433. Hayes, K.; Sliwa, C.; Migus, S.; McEnnulty, F.; Dunstan, P. National Priority Pests: Part II Ranking of Australian Marine Pests. In An independent report undertaken for the Department of Environment and Heritage by CSIRO Marine Research; Australian Government Department of the Environment and Heritage: Canberra, Australia, 2005; pp. 1-106.

434. Ferrario, J.; Minchin, D. Spread of the non-indigenous serpulid Hydroides sanctaecrucis Krøyer in Mörch, 1863 in the Pacific Ocean: A new record from Taiwan. Bioinvasions Rec. 2017, 6, 33-38. [CrossRef]

435. Lee, A.L.; Dafforn, K.A.; Hutchings, P.A.; Johnston, E.L. Reproductive strategy and gamete development of an invasive fanworm, Sabella spallanzanii (Polychaeta: Sabellidae), a field study in Gulf St Vincent, South Australia. PLoS ONE 2018, 13 , e0200027.

436. Clapin, G.; Evans, D.R. The status of the introduced marine fanworm Sabella spallanzanii in Western Australia: A preliminary investigation. Cent. Res. Introd. Mar. Pests Tech. Rep. 1995, 2, 1-34.

437. Yee, A.; Mackie, J.; Pernet, B. The distribution and unexpected genetic diversity of the non-indigenous annelid Ficopomatus enigmaticus in California. Aquat. Invasions 2019, 14, 250-266. [CrossRef]

438. Oliva, M.; De Marchi, L.; Sanches, M.V.; Pires, A.; Cuccaro, A.; Baratti, M.; Chiellini, F.; Morelli, A.; Freitas, R.; Pretti, C. Atlantic and Mediterranean populations of the widespread serpulid Ficopomatus enigmaticus: Developmental responses to carbon nanotubes. Mar. Pollut. Bull. 2020, 156, 111265. [CrossRef] [PubMed]

439. Zibrowius, H. Serpulidae (Annelida Polychaeta) de l'Ocean Indien arrives sur des Coques de Bateaux a Toulon (France, Mediterranee). Rapports et Proces Verbaux des Reunions Commission Internationale pour l'Exploration Scientifique de la Mer Mediterranee Monaco 1979, 25-26, 133-134.

440. Ben-Eliahu, M.N. Red Sea serpulids (Polychaeta) in the Eastern Mediterranean. Ophelia Suppl. 1991, 5, 515-528. 
441. Zenetos, A.; Çinar, M.E.; Crocetta, F.; Golani, D.; Rosso, A.; Servello, G.; Shenkar, N.; Turon, X.; Verlaque, M. Uncertainties and validation of alien species catalogues: The Mediterranean as an example. Estuar. Coast. Shelf Sci. 2017, 191, 171-187. [CrossRef]

442. Streftaris, N.; Zenetos, A. Alien marine species in the Mediterranean-the 100 'worst invasives' and their impact. Mediterr. Mar. Sci. 2006, 7, 87-118. [CrossRef]

443. Dürr, S.; Watson, D.I. Biofouling and antifouling in aquaculture. Biofouling 2010, 12, 267-287.

444. Wang, J.; Huang, Z. Fouling polychaetes of Hong Kong and adjacent saters. Asian Mar. Biol. 1993, 10, 1-12.

445. Mohan, P.C.; Aruna, C. The biology of serpulid worms in relation to biofouling. In Recent Developments in Biofouling Control; Thompson, M.F., Nagabhushanam, R., Sarojini, R., Fingerman, M., Eds.; Oxford \& IBH Publishing Company: New Delhi, India, 1994; pp. 59-64.

446. Fitridge, I.; Dempster, T.; Guenther, J.; De Nys, R. The impact and control of biofouling in marine aquaculture: A review. Biofouling 2012, 28, 649-669. [CrossRef] [PubMed]

447. Schloesser, D.W.; Malakauskas, D.M.; Malakauskas, S.J. Freshwater polychaetes (Manayunkia speciosa) near the Detroit River, Western Lake Erie: Abundance and life-history characteristics. J. Great Lakes Res. 2016, 42, 1070-1083. [CrossRef]

448. Read, G.B.; Gordon, D.P. Adventive occurrence of the fouling serpulid Ficopomatus enigmaticus (Polychaeta) in New Zealand. N. Z. J. Mar. Freshw. Res. 1991, 25, 269-273. [CrossRef]

449. Probert, P.K. First record of the introduced fouling tubeworm Ficopomatus enigmaticus (Polychaeta: Serpulidae) in Hawke Bay, New Zealand. N. Z. J. Zool. 1993, 20, 35-36. [CrossRef]

450. Pernet, B.; Barton, M.; Fitzhugh, K.; Harris, L.; Lizárraga, D.; Ohl, R.; Whitcraft, C. Establishment of the reef-forming tubeworm Ficopomatus enigmaticus (Fauvel, 1923) (Annelida: Serpulidae) in Southern California. Bioinvasions Rec. 2016, 5, 13-19. [CrossRef]

451. Heiman, K.W.; Micheli, F. Non-native ecosystem engineer alters Estuarine communities. Integr. Comp. Biol. 2010, 50, 226-236. [CrossRef] [PubMed]

452. Ulman, A.; Ferrario, J.; Forcada, A.; Seebens, H.; Arvanitidis, C.; Occhipinti-Ambrogi, A.; Marchini, A. Alien species spreading via biofouling on recreational vessels in the Mediterranean Sea. J. Appl. Ecol. 2019, 56, 2620-2629. [CrossRef]

453. Secretaría de Medio Ambiente y Recursos Naturales, Estados Unidos Mexicanos. Acuerdo por el que se Determina la Lista de las Especies Exóticas Invasoras Para México; Secretaría de Medio Ambiente y Recursos Naturales: Ciudad de México, Mexico, 2016.

454. Mackie, G.L.; Qadri, S.U. A polychaete, Manayunkia speciosa, from the Ottawa River, and Its North American distribution. Canad. J. Zool. 1971, 49, 780-782. [CrossRef]

455. Stocking, R.W.; Bartholomew, J.L. Distribution and habitat characteristics of Manayunkia speciosa and infection prevalence with the parasite Ceratomyxa shasta in the Klamath River, Oregon-California. J. Parasitol. 2007, 93, 78-88. [CrossRef] [PubMed]

456. Piazzolla, D.; Cafaro, V.; Mancini, E.; Scanu, S.; Bonamano, S.; Marcelli, M. Preliminary investigation of microlitter pollution in low-energy hydrodynamic basins using Sabella spallanzanii (Polychaeta: Sabellidae) tubes. Bull. Environ. Contam. Toxicol. 2020, 104, 345-350. [CrossRef]

457. Gopalakrishnan, S.; Thilagam, H.; Raja, P.V. Comparison of heavy metal toxicity in life stages (spermiotoxicity, egg toxicity, embryotoxicity and larval toxicity) of Hydroides elegans. Chemosphere 2008, 71, 515-528. [CrossRef] [PubMed]

458. Thilagam, H.; Gopalakrishnan, S.; Vijayavel, K.; Raja, P.V. Effluent toxicity test using developmental stages of the marine polychaete Hydroides elegans. Arch. Environ. Contam. Toxicol. 2008, 54, 674-683. [CrossRef]

459. Vijayaragavan, S.; Raja, P.V. The toxic effects of phorate on early embryonic stages of sedentary polychaete Hydroides elegans (Haswell, 1883). J. Basic Appl. Zool. 2018, 79, 45. [CrossRef]

460. Bellante, A.; Piazzese, D.; Cataldo, S.; Parisi, M.G.; Cammarata, M. Evaluation and comparison of trace metal accumulation in different tissues of potential bioindicator organisms: Macrobenthic filter feeders Styela plicata, Sabella spallanzanii, and Mytilus galloprovincialis. Environ. Toxicol. Chem. 2016, 35, 3062-3070. [CrossRef]

461. Giangrande, A.; Licciano, M.; Del Pasqua, M.; Fanizzi, F.P.; Migoni, D.; Stabili, L. Heavy metals in five Sabellidae species (Annelida, Polychaeta): Ecological implications. Environ. Sci. Pollut. Res. 2017, 24, 3759-3768. [CrossRef]

462. Xie, Z.-C.; Wong, N.C.; Qian, P.-Y.; Qiu, J.-W. Responses of polychaete Hydroides elegans life stages to copper stress. Mar. Ecol. Prog. Ser. 2005, 285, 89-96. [CrossRef]

463. Gopalakrishnan, S.; Thilagam, H.; Raja, P. Toxicity of heavy metals on embryogenesis and larvae of the marine sedentary polychaete Hydroides elegans. Arch. Environ. Contamin. Toxicol. 2007, 52, 171-178. [CrossRef] [PubMed]

464. Ross, K.E.; Bidwell, J.R. A 48-h larval development toxicity test using the marine polychaete Galeolaria caespitosa Lamarck (Fam. Serpulidae). Arch. Environ. Contamin. Toxicol. 2001, 40, 489-496.

465. Giangrande, A.; Cavallo, A.; Licciano, M.; Mola, E.; Pierri, C.; Trianni, L. Utilization of the filter feeder polychaete Sabella. Aquac. Int. 2005, 13, 129-136. [CrossRef]

466. Licciano, M.; Stabili, L.; Giangrande, A.; Cavallo, R.A. Bacterial accumulation by Branchiomma luctuosum (Annelida: Polychaeta): A tool for biomonitoring marine systems and restoring polluted waters. Mar. Environ. Res. 2007, 63, 291-302. [CrossRef]

467. Pierri, C.; Fanelli, G.; Giangrande, A. Experimental co-culture of low food-chain organisms, Sabella spallanzanii (Polychaeta, Sabellidae) and Cladophora prolifera (Chlorophyta, Cladophorales), in Porto Cesareo area (Mediterranean Sea). Aquac. Res. 2006, 37, 966-974. [CrossRef]

468. Stabili, L.; Licciano, M.; Giangrande, A.; Longo, C.; Mercurio, M.; Marzano, C.N.; Corriero, G. Filtering Activity of Spongia officinalis var. adriatica (Schmidt) (Porifera, Demospongiae) on bacterioplankton: Implications for bioremediation of polluted seawater. Water Res. 2006, 40, 3083-3090. [CrossRef] 
469. Stabili, L.; Licciano, M.; Lezzi, M.; Giangrande, A. Microbiological accumulation by the Mediterranean invasive alien species Branchiomma bairdi (Annelida, Sabellidae): Potential tool for bioremediation. Mar. Pollut. Bull. 2014, 86, 325-331. [CrossRef]

470. Stabili, L.; Licciano, M.; Giangrande, A.; Gerardi, C.; De Pascali, S.A.; Fanizzi, F.P. First insight on the mucus of the annelid Myxicola infundibulum (Polychaeta, Sabellidae) as a potential prospect for drug discovery. Mar. Drugs 2019, 17, 396. [CrossRef]

471. Soto, D. Integrated Mariculture: A Global Review.; Food and Agriculture Organization of the United Nations (FAO): Rome, Italy, 2009.

472. Stewart, B.; Davies, B. Effects of macrophyte harvesting on invertebrates associated with Potamogeton pectinatus L. in the Marina Da Gama, Zandvlei, Western Cape. Trans. R. Soc. S. Africa 1986, 46, 35-49. [CrossRef]

473. Joyce, C.B.; Vina-Herbon, C.; Metcalfe, D.J. Biotic variation in coastal water bodies in Sussex, England: Implications for saline lagoons. Estuar. Coast. Shelf Sci. 2005, 65, 633-644. [CrossRef]

474. Davies, B.; Stuart, V.; De Villiers, M. The filtration activity of a serpulid polychaete population (Ficopomatus enigmaticus (Fauvel) and its effects on water quality in a coastal marina. Estuar. Coast. Shelf Sci. 1989, 29, 613-620. [CrossRef]

475. Licciano, M.; Watson, G.J.; Murray, J.M.; Giangrande, A. Evidence of regenerative ability in Myxicola infundibulum (Annelida, Sabellida): Evolutionary and systematic implications. Invertebr. Biol. 2015, 134, 48-60. [CrossRef]

476. Bely, A.E. Distribution of segment regeneration ability in the Annelida. Integr. Comp. Biol. 2006, 46, 508-518. [CrossRef] [PubMed]

477. Prentiss, N.K.; Tyler, M.S.; Dean, D.A. Morphological and histological investigation of the regeneration in Myxicola infundibulum (Montagu, 1808) (Sabellida, Annelida). Mar. Biol. Assoc. UK 2017, 97, 1155-1165. [CrossRef]

478. Nicol, J. The giant nerve-fibres in the central nervous system of Myxicola (Polychaeta, Sabellidae). Q. J. Micros. Sci. 1948, 3, 1-45

479. Roberts, M.B.V. The Rapid response of Myxicola infundibulum (Grube). J. Mar. Biol. Assoc. U.K. 1962, 42, 527-539. [CrossRef]

480. Gilbert, D. Axoplasm architecture and physical properties as seen in the Myxicola giant axon. J. Physiol. 1975, $253,257-301$. [CrossRef]

481. Barry, J.F.; Turner, M.J.; Schloss, J.M.; Glenn, D.R.; Song, Y.; Lukin, M.D.; Park, H.; Walsworth, R.L. Optical magnetic detection of single-neuron action potentials using quantum defects in diamond. Proc. Natl. Acad. Sci. USA 2016, 113, 14133-14138. [CrossRef]

482. Purschke, G. Annelida: Basal groups and Pleistoannelida. In Structure and Evolution of Invertebrate Nervous Systems; SchmidtRhaesa, A., Harzsch, S., Purschke, G., Eds.; Oxford University Press: Oxford, UK, 2016; pp. 254-312.

483. Schauf, C.; Davis, F.A.; Marder, J. Effects of carbamazepine on the ionic conductances of Myxicola giant axons. J. Pharmacol. Exp. Ther. 1974, 189, 538-543.

484. Nedved, B.T.; Hadfield, M.G. Hydroides elegans (Annelida: Polychaeta): A model for biofouling research. In Marine and Industrial Biofouling; Flemming, H.-S., Sriyutha Murthy, P., Venkatesan, R., Cooksey, K., Eds.; Springer Series on Biofilms: Los Angeles, CA, USA, 2008; Volume 4, pp. 203-218.

485. Hadfield, M.G. The D.P. Wilson Lecture. Research on settlement and metamorphosis of marine invertebrate larvae: Past, present and future. Biofouling 1998, 12, 9-29. [CrossRef]

486. Hadfield, M.G. Biofilms and marine invertebrate larvae: What bacteria produce that larvae use to choose settlement sites. Ann. Rev. Mar. Sci 2011, 3, 453-470. [CrossRef] [PubMed]

487. Qian, P.-Y. Larval settlement of polychaetes. Hydrobiologia 1999, 402, 239-253. [CrossRef]

488. Hadfield, M.G.; Nedved, B.T.; Wilbur, S.; Koehl, M. Biofilm cue for larval settlement in Hydroides elegans (Polychaeta): Is contact necessary? Mar. Biol. 2014, 161, 2577-2587. [CrossRef]

489. Shikuma, N.J.; Antoshechkin, I.; Medeiros, J.M.; Pilhofer, M.; Newman, D.K. Stepwise metamorphosis of the tubeworm Hydroides elegans is mediated by a bacterial inducer and MAPK Signaling. Proc. Natl. Acad. Sci. USA 2016, 113, 10097-10102. [CrossRef] [PubMed]

490. Vijayan, N.; Lema, K.A.; Nedved, B.T.; Hadfield, M.G. Microbiomes of the polychaete Hydroides elegans (Polychaeta: Serpulidae) across its life-history stages. Mar. Biol. 2019, 166, 19. [CrossRef]

491. Toonen, R.J.; Pawlik, J.R. Foundations of gregariousness. Nature 1994, 370, 511-512. [CrossRef]

492. Toonen, R.J.; Pawlik, J.R. Settlement of the gregarious tube worm Hydroides dianthus (Polychaeta: Serpulidae): Cues for gregarious settlement. Mar. Biol. 1996, 126, 725-733. [CrossRef]

493. Toonen, R.; Pawlik, J. Settlement of the gregarious tube worm Hydroides dianthus (Polychaeta: Serpulidae). I. gregarious and nongregarious settlement. Mar. Ecol. Prog. Ser. 2001, 224, 103-114. [CrossRef]

494. Kenny, N.J.; Shimeld, S.M. Additive multiple k-mer transcriptome of the keelworm Pomatoceros lamarckii (Annelida; Serpulidae) reveals annelid trochophore transcription factor cassette. Dev. Genes Evol. 2012, 222, 325-339. [CrossRef]

495. Barton-Owen, T.B.; Szabó, R.; Somorjai, I.M.; Ferrier, D.E. A revised spiralian homeobox gene classification incorporating new polychaete transcriptomes reveals a diverse TALE class and a divergent hox gene. Genome Biol. Evol. 2018, 10, $2151-2167$. [CrossRef] [PubMed]

496. Szabó, R.; Ferrier, D.E.K. Cell proliferation dynamics in regeneration of the operculum head appendage in the annelid Pomatoceros lamarckii. J. Exp. Zool. Part. B Mol. Dev. Evol. 2014, 322, 257-268. [CrossRef] [PubMed]

497. Szabó, R.; Ferrier, D.E. Another biomineralising protostome with an $m s p 130$ gene and conservation of $m s p 130$ gene structure across Bilateria. Evol. Dev. 2015, 17, 195-197. [CrossRef]

498. San Chan, V.B.; Li, C.; Lane, A.C.; Wang, Y.; Lu, X.; Shih, K.; Zhang, T.; Thiyagarajan, V. $\mathrm{CO}_{2}$-driven ocean acidification alters and weakens integrity of the calcareous tubes produced by the serpulid tubeworm, Hydroides elegans. PLoS ONE 2012, 7, e42718. [CrossRef] 
499. Lane, A.C.; Mukherjee, J.; Chan, V.B.; Thiyagarajan, V. Decreased pH does not alter metamorphosis but compromises juvenile calcification of the tube worm Hydroides elegans. Mar. Biol. 2013, 160, 1983-1993. [CrossRef]

500. Díaz-Castañeda, V.; Cox, T.E.; Gazeau, F.; Fitzer, S.; Delille, J.; Alliouane, S.; Gattuso, J.-P. Ocean acidification affects calcareous tube growth in adults and reared offspring of serpulid polychaetes. J. Exp. Biol. 2019, 222, jeb196543. [CrossRef]

501. Wabnitz, C. From Ocean to Aquarium: The Global Trade in Marine Ornamental Species; UNEP/Earthprint: Cambridge, UK, 2003.

502. Murray, J.M.; Watson, G.J.; Giangrande, A.; Licciano, M.; Bentley, M.G. Managing the marine aquarium trade: Revealing the data gaps using ornamental polychaetes. PLoS ONE 2012, 7, e29543. [CrossRef] [PubMed]

503. Bybee, D.R.; Murray, J.M. Polychaetes. Mar. Ornam. Spec. Aquacult. 2017, 1, 565-579.

504. Bybee, D.R.; Bailey-Brock, J.H.; Tamaru, C.S. Larval development of Sabellastarte spectabilis (Grube, 1878) (Polychaeta: Sabellidae) in Hawaiian waters. Sci. Mar. 2006, 70, 279-286. [CrossRef]

505. Bybee, D.R.; Bailey-Brock, J.H.; Tamaru, C.S. Evidence for sequential hermaphroditism in Sabellastarte spectabilis (Polychaeta: Sabellidae) in Hawai'i. Pac. Sci. 2006, 60, 541-547. [CrossRef]

506. Bybee, D.R.; Bailey-Brock, J.H.; Tamaru, C.S. Gametogenesis and spawning periodicity in the fan worm Sabellastarte spectabilis (Polychaeta: Sabellidae). Mar. Biol. 2007, 151, 639-648. [CrossRef]

507. Murray, J.M. Regeneration and Reproduction in Sabella pavonina (Savigny): Developing a Novel Method to Culture Marine Ornamental Sabellids. Ph.D. Thesis, University of Portsmouth, Portsmouth, UK, 2010.

508. Dávila-Jiménez, Y.; Tovar-Hernández, M.A.; Simōes, N. The social feather duster worm Bispira brunnea (Polychaeta: Sabellidae): Aggregations, morphology and reproduction. Mar. Biol. Res. 2017, 13, 782-796. [CrossRef]

509. Alalykina IL, Polychaeta. A review of the deep-sea benthic polychaetes along the NW Pacific. In Biogeographical Atlas of the Deep NW Pacific Fauna; Pensoft Publishers: Sofia, Bulgaria, 2020; pp. 175-212.

510. Gunton, L.M.; Kupriyanova, E.K.; Alvestad, T.; Avery, L.; Blake, J.A.; Biriukova, O.; Böggemann, M.; Borisova, P.; Budaeva, N.; Burghardt, I.; et al. Annelids of the eastern Australian abyss collected by the 2017 RV 'Investigator'voyage. ZooKeys 2021, 1020, 1-198. [CrossRef]

511. Simon, C. The wonderful world of worms. Quest 2014, 10, 32-34.

512. Ippolitov, A.; Rzhavsky, A. Tube morphology, ultrastructures and mineralogy in recent Spirorbinae (Annelida; Polychaeta; Serpulidae). I. General introduction. Tribe Paralaeospirini. Invertebr. Zool. 2014, 11, 293-314. [CrossRef]

513. Sigvaldadóttir, E.; Mackie, A.S. Prionospio steenstrupi, P. fallax and P. dubia (Polychaeta, Spionidae): Re-evaluation of identity and status. Sarsia 1993, 78, 203-219. [CrossRef]

514. Martin, D.; Britayev, T.A.; San Martín, G.; Gil, J. Inter-population variability and character description in the sponge-associated Haplosyllis spongicola complex (Polychaeta: Syllidae). In Advances in Polychaete Research; Springer: Dordrecht, The Netherlands, 2003; pp. 145-162.

515. Ten Hove, H.A.; Jansen-Jacobs, M.J. A Revision of the genus Crucigera (Polychaeta; Serpulidae); A proposed methodical approach to serpulids, with special reference to variation in Serpula and Hydroides. In Proceedings of the First International Polychaete Conference; Hutchings, P.A., Ed.; Linnean Society of New South West: Sydney, Australia, 1984; pp. 143-180.

516. Watanabe, M.E. The evolution of natural history collections: New research tools move specimens, data to center stage. Bioscience 2019, 69, 163-169. [CrossRef]

517. Annenkova, N.P. Polychaeta of the North Japan Sea and their horizontal and vertical distribution. USSR Hydrobiological Expedition in 1934 to the Japan Sea. Trudy Daln. Filiala Akademii Nauk SSSR 1938, 1, 81-230. (In Russian)

518. Oug, E.; Bakken, T.; Kongsrud, J.A. Original specimens and type localities of early described polychaete species (Annelida) from Norway, with particular attention to species described by O. F. Müller and M. Sars. Mem. Mus. Vic. 2014, 71, 217-236. [CrossRef]

519. Montagu, G. Testacea Brittanica or Natural History of British Shells, Marine, Land and Fresh-Water, Including the Most Minute: Systematically Arranged and Embellished with Figures. Part II; White: London, UK, 1803; pp. $293-606$.

520. Von Siebold, C.T. Bericht Über die Leistungen in der Naturgeschichte der Würmer, Zoophyten und Protozoen Während der Jahre 1845, 1846 und 1847. Arch. Naturgesch. 1850, 16, 351-468. 